SEISMIC VELOCITIES AND GEOLOGICAL CONDITIONS AT TWELVE SITES SUBJECTED TO STRONG GROUND MOTION IN THE 1994 NORTHRIDGE, CALIFORNIA, EARTHQUAKE

by

James F. Gibbs, John C. Tinsley, and William B. Joyner ${ }^{1}$

U.S. Geological Survey Open-File Report 96-740

This report is preliminary and has not been reviewed for conformity with U.S. Geological Survey editorial standards or with the North American Stratigraphic Code. Any use of trade, product, or firm names is for discriptive purposes only and does not imply endorsement by the U.S. Government.

${ }^{1}$ Menlo Park, CA 94025 


\section{TABLE OF CONTENTS}

Page

Introduction . . . . . . . . . . . . . . . . 1

Regional Geologic Setting . . . . . . . . . . . . . . 1

Acceleograph Sites and Areal Geology . . . . . . . . . . . . 7

Geologic and Geophysical Logs . . . . . . . . . . . . . . . 8

$P$ - and $S$-Wave Travel-Time Data . . . . . . . . . . . . . 8

Determining Velocity Profiles . . . . . . . . . . . . . . 9

Summary Velocity Profiles . . . . . . . . . . . . . . . . . 11

Acknowledgments . . . . . . . . . . . . . . . . . 11

References .................. 18

Appendix-Detailed Results:

Epiphany Lutheran Church . . . . . . . . . . . . . . . . . 20

Jensen Generator Building . . . . . . . . . . . . 27

Jensen Main Building . . . . . . . . . . . . . . . . 34

Knolls Elementary School . . . . . . . . . . . . . . . . 41

Los Angeles Dam . . . . . . . . . . . . . . . . . . . . . . . 48

Olive View Hospital . . . . . . . . . . . . . . . . 55

Rinaldi Receiving Station . . . . . . . . . . . . . . 62

Sepulveda V.A. Hospital . . . . . . . . . . . . . . . 69

Sherman Oaks Park . . . . . . . . . . . . . . 76

Sherman Oaks Woodman . . . . . . . . . . . . 83

Sylmar Converter West . . . . . . . . . . . . . . . . . . . . . . 90 90

White Oak Church . . . . . . . . . . . . 97 


\title{
SEISMIC VELOCITIES AND GEOLOGICAL CONDITIONS AT TWELVE SITES SUBJECTED TO STRONG GROUND MOTION \\ IN THE 1994 NORTHRIDGE, CALIFORNIA, EARTHQUAKE
}

by

\author{
James F. Gibbs, John C. Tinsley, and William B. Joyner
}

\section{INTRODUCTION}

The Northridge, California, earthquake of January 17, 1994 (moment magnitude 6.7) was perhaps the best recorded earthquake in history from the standpoint of strong ground motion. As part of the U.S. Geological Survey's ongoing program for documenting the relationship between strong ground motion and geologic and seismic site conditions, twelve boreholes, each approximately 100 meters deep, were drilled at sites affected by the Northridge earthquake. Ten of the boreholes were located at strong-motion recording sites; the other two were located at sites in the Sherman Oaks district of Los Angeles to evaluate an apparent relationship between site conditions and building damage noted there. At each site lithologic descriptions were compiled from observations of drill cuttings and cored samples. At each site four different types of electric logs were made, and downhole $P$ - and $S$-wave velocities were measured. Preliminary results are presented in this report. The sites are shown in Figure 1 and listed in Table 1, which gives references to information regarding the strong-motion data. The Appendix contains, for each site, a location map, $S$ and $P$-wave record sections, a time-depth plot, velocity profiles with a simplified geologic $\log$, and tables giving arrival times and velocity values.

\section{REGIONAL GEOLOGIC SETTING}

The San Fernando Valley (Figure 2) is one of several east-west-trending, deep, alluviated basins situated within the the Transverse Ranges structural province of southern California, a region noted for its intense and relatively young deformation and its locally complex structural setting. The regional geology has received recent intense scrutiny and reevaluation of its neotectonic setting, chiefly owing to the Northridge earthquake of $1 / 17 / 94$ and the San Fernando earthquake of 2/9/71 (Wentworth et al., 1971). The San 


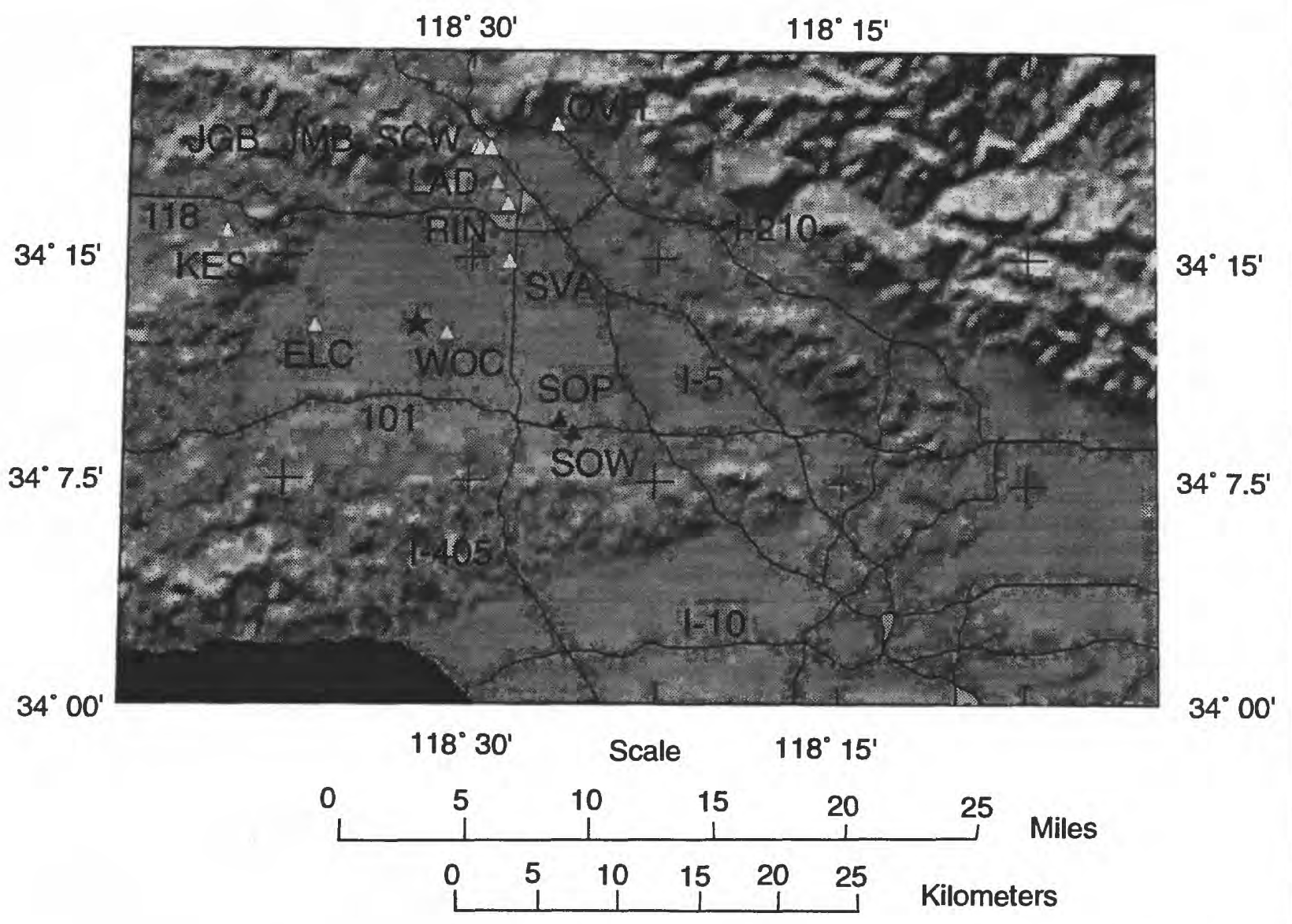

$\triangle \quad$ Strong-motion seismograph site investigated by USGS (this report)

- Sherman Oaks sites investigated by USGS (this report)

$\star \quad$ Epicenter of January 17, 1994 earthquake

Figure 1. Regional map showing the locations of boreholes (triangles) included in this report. The epicenter of the January 17, 1994, Northridge, California, earthquake is indicated by the star. 


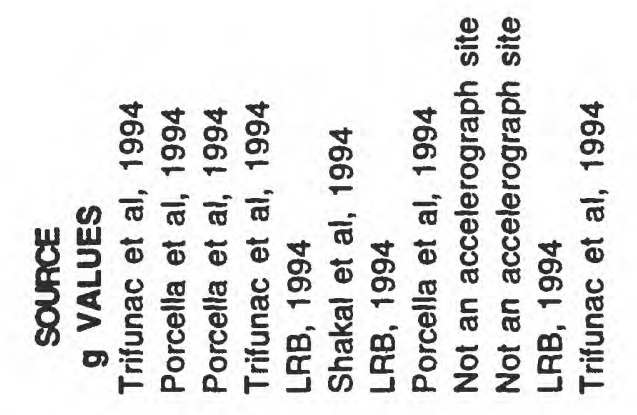

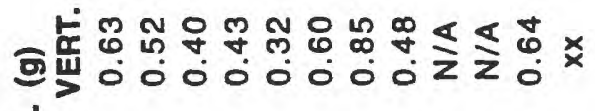

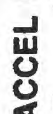

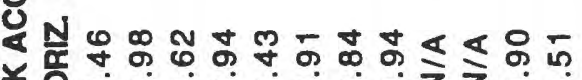

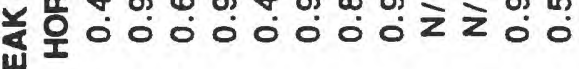
뜸

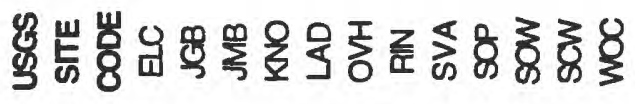

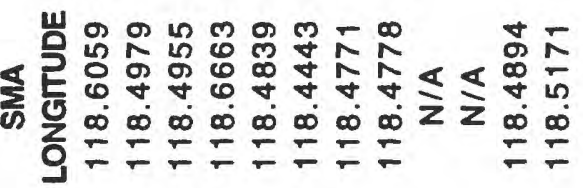

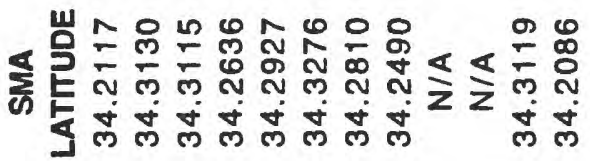

趂

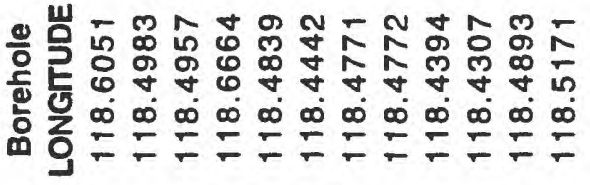

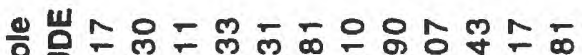

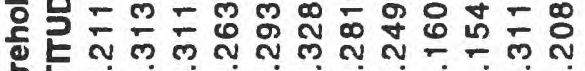

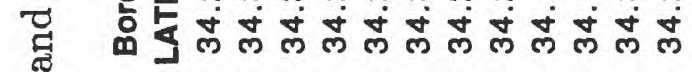

兽

$-$

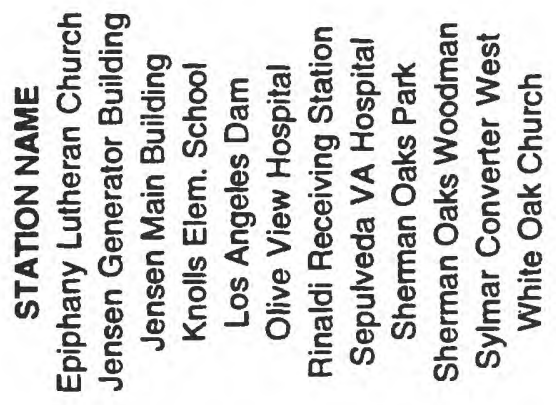

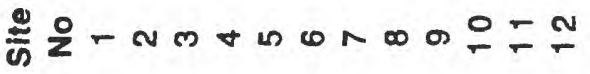




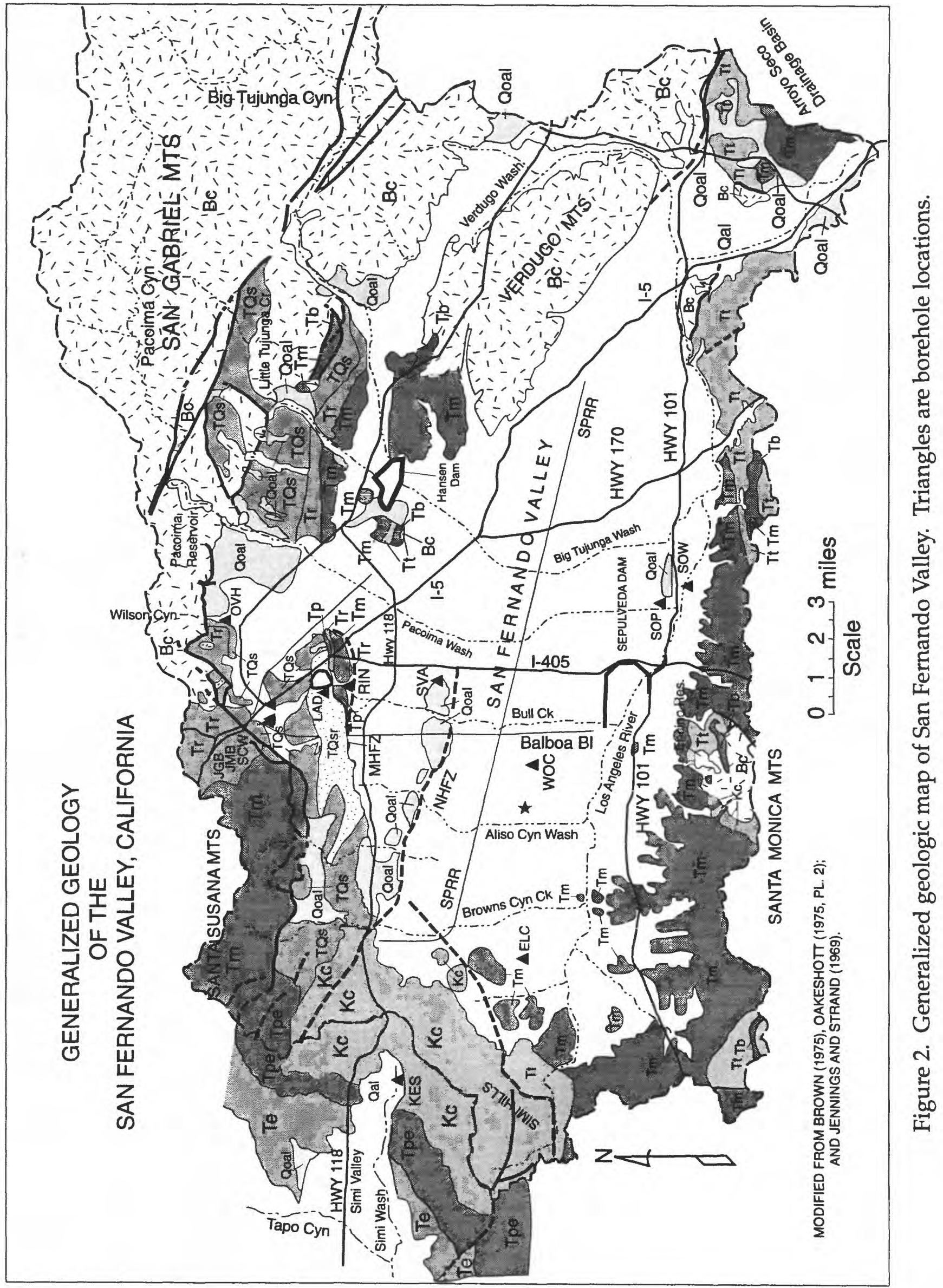




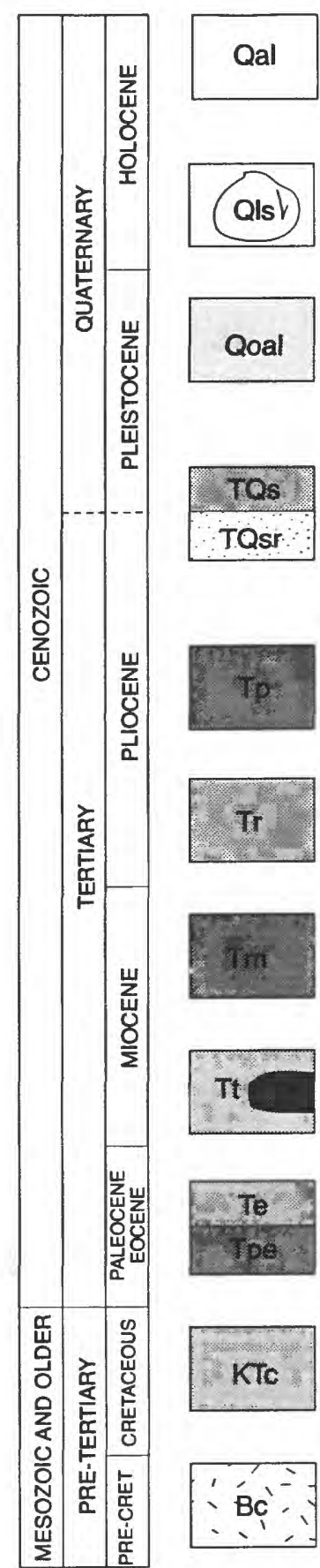

Modelo (Puente) Formation: arkosic conglomerate, sandstone, and diatomaceous and silicious shales; marine.

Topanga Formation: Brown, tan and gray sandstone and conglomerate; marine. Includes interbedded andesite and basalt flows as map unit Tb.

Martinez, Domengine, and Las LLajas formations: Sandstone, dark shale, and conglomerate; marine, greenish-black. Includes marine deposits of Paleocene (Tpe) and Eocene (Te) age.

Chico Formation: Massive brown sandstone with subordinate thin beds of shale; marine. Locally known as Chatsworth Formation and is of late Cretaceous age.

Basement Complex: Includes undifferentiated metamorphic and granitic rocks of eastern basement complex of Yerkes (1965) and in Santa Monica Mountains, the Santa Monica Slate (western basement complex of Yerkes (1965); these suites have continental and oceanic crustal protoliths, respectively.

Freeway linework scanned from aerial photography, positioning is not precise.

Fault, dashed where location is approximate, dotted where concealed.

Note: faults shown are schematically depicted and are not comprehensively mapped.

NHFZ = Northridge Hills Fault Zone; MHFZ = Mission Hills Fault Zone;

SPRR $=$ Southern Pacific Railroad

Red (light) triangle is USGS study site at an accelerograph location; black (dark) triangle is USGS study site that does not correspond to an accelerograph site.

Epicenter of 1/17/94 Northridge, California, earthquake

Figure 2. Explanation. 
Fernando Valley encompasses more than 300,000 acres below its drainage divides and above the confluence of the Los Angeles River with the Arroyo Seco; of these, about 120,000 acres comprise the relatively gently sloping, alluviated basin floor, now very densely populated with homes and businesses (Brown, 1975; California State Water Rights Board, 1962). The valley fill strongly reflects the geology of the surrounding mountains and foothills, a characteristic with implications for regional interpretations of shear wave velocity profiles. Consequently, conspicuous differences in sediment supply distinguish the eastern from the western portions of the San Fernando Valley, with the dividing line being the Bull Creek drainage, which is situated between Balboa Blvd. and Interstate 405.

The eastern half of the alluviated San Fernando Valley receives sediment from steep drainages characteristic of the rugged San Gabriel and Verdugo mountains. These mountainous terranes expose mainly crystalline granitic and metamorphic rocks of the eastern basement complex of Yerkes (1965). Consequently, the valley fill deposits located east of Interstate 405 are relatively coarse-textured and comprised of sand, gravel, and cobbles deposited by the powerful high-gradient streams draining such principal watercourses as Big Tujunga, Little Tujunga, and Pacoima canyons. These sediment transport systems have shunted the Los Angeles River southward nearly to the Santa Monica mountains, limiting the areal extent of the sediment eroded from the Santa Monica mountains.

The western half of the San Fernando Valley receives alluvial sediment from numerous drainages dissecting the Santa Monica mountains, the Santa Susana mountains, and the Simi Hills. These drainage basins are smaller than those of the San Gabriel mountains, and are eroding uplands comprised mainly of Mesozoic, Tertiary, and early Quaternary uplifted marine and nonmarine sandstones, siltstones, and mudrocks (Winterer and Durham, 1958, 1962). A small area of Santa Monica mountains exposes rocks of the western basement complex of Yerkes et al. (1965) locally represented by the Santa Monica slate. The valley's alluvial deposits thus are significantly more fine-textured at most localities west of Interstate 405 compared to those east of Interstate 405 . The western portion of the valley contains significant occurrences of very shallow ground water (California State Water Rights Board (1962); Tinsley et al. (1985), Tinsley and Fumal (1985)). Areas characterized 
by high sedimentation rates owing to persistent overbank flooding and fine-grained debrisflows (relatively common events prior to implementation of flood control measures in the western San Fernando Valley [King et al., 1981]) and a persistence of shallow ground water are distinguished by relatively low values of shear strength and contained the lowest shearwave velocities we measured in this study.

\section{ACCELEOGRAPH SITES AND AREAL GEOLOGY}

The sites we investigated and report here comprise a relevant set of data for exploring aspects of site dependent effects of the Northridge earthquake. However, we caution that these sites do not encompass a complete sampling of the region's varied geology. Six sites occur on recent alluvium deposited by streams draining Cretaceous and Tertiary marine sediments. Of these, five sites are located on relatively fine-textured surficial deposits (chiefly well bedded sequences composed of poorly consolidated loose to slightly dense silty sand, sandy silt, silt, and clayey silt) in the western half of the San Fernando Valley (ELC, RIN, WOC), in the south central San Fernando Valley (SOP, SOW) and one site is located in southeasternmost Simi Valley (KES) on sand and silt deposits derived from the Cretaceous Chatsworth Formation, (the sedimentary rock that forms the visually impressive brown-weathering sandstone that crops out in the northwestern San Fernando Valley and eastern Simi Valley). About 12 meters of Quaternary sediment overlies the Cretaceous bedrock at this point in Simi Valley. At one site (SVA), Pleistocene sandy and silty alluvial deposits overlie strata of the Saugus Formation or its stratigraphic equivalent.

Boreholes drilled at three sites (JMB, JGB, SCW) penetrated various thicknesses of fill and soft Holocene alluvial deposits before encountering the Saugus Formation of Winterer and Durham (1962). A fourth site, the Los Angeles Dam (LAD) site, is the only site we investigated that was within the lower (Sunshine Ranch) member of the Saugus Formation; shear-wave velocities for the LAD site are higher than those measured in the other Saugus Formation sites. The 12th and final site was located at Olive View Hospital, in coarse, gravelly alluvium derived from Wilson Canyon, which drains granitic and metamorphic rocks of the San Gabriel mountains. This site is the only site that encountered materials typical of much of the eastern half of the San Fernando Valley. 


\section{GEOLOGIC AND GEOPHYSICAL LOGS}

Generalized logs of earth materials underlying the drill sites were prepared from (1) mud logs of cuttings that were noted during drilling, (2) "undisturbed"samples obtained using a Pitcher sampler, (which provided glimpses of the materials encountered at depth) and (3) a suite of geophysical logs (spontaneous potential, resistivity, caliper, and natural gamma ray logs, these logs are not included here, but will appear in a later report) obtained prior to installing and grouting the casing in the borehole. From these logs we can delineate the thickness and character of basin alluvial deposits and underlying bedrock. Electric logs enable findings to be correlated to other parts of the basin and to other basins in southern California. Physical properties noted in the abbreviated descriptions include; depth, color, texture or lithology of alluvial deposits, probably geologic age, and correlation with regionally mapped geologic units.

$P$ - AND $S$-WAVE TRAVEL-TIME DATA

Shear waves were generated at the ground surface by an air-powered horizontal hammer (Liu, et al., 1988) striking an anvil at either end of an aluminum channel 2.3 $\mathrm{m}$ long. The hammer was driven first in one direction and then in the other to generate pulses of opposite polarity. A switch attached to the shear source triggered the recorder and established the reference for timing arrivals. $P$-waves were made by striking a steel plate with a sledge hammer. A switch attached to the handle of the sledge hammer triggered the recorder. $P$ - and $S$-wave sources were offset from the borehole to minimize the effect of waves traveling down the grout surrounding the casing. The offset was $4 \mathrm{~m}$ at all sites except Jensen Main Building, where it was $5 \mathrm{~m}$. Travel times were corrected to vertical before used to determine velocity.

Downhole measurements were made at $2.5 \mathrm{~m}$ intervals with a three-component geophone clamped to the casing by an electrically-activated lever arm. A second threecomponent geophone was placed on the surface 5 to $10 \mathrm{~m}$ from the shear source for recording an on-scale reference trace, which was useful for amplitude studies and timing verification. The data were recorded on diskettes by a 12-channel recording system. 


\section{DETERMINING VELOCITY PROFILES}

The procedure for determining velocities is summarized in Figure 3. The orientation of the downhole geophone could not be controlled when moving from one depth to the next, so, the orientation was unknown and changed with depth. To minimize the effects of those changes the horizontal components were rotated to the direction that maximized the integral square amplitude within a time interval containing the shear wave (Boatwright et $a l ., 1986) . P$ - and $S$-wave arrival times were determined from the time series displayed on a 20-inch computer screen at each depth. The $P$-wave arrival time was obtained from the vertical trace, and the $S$-wave arrival times were obtained from the rotated horizontal traces for the two hammer blows in opposite directions and averaged. The arrivals were timed to the nearest millisecond, probably a realistic precision for clear arrivals uncontaminated by noise.

The $S$-wave travel-time data were analyzed first. A trial set of layer boundaries was chosen on the basis of the lithologic descriptions and the geophysical logs. Using a leastsquares program from Press et al. (1992), the travel-time data were fit with a continuous set of straight-line segments, hinged at the layer boundaries and fixed at zero at the surface. The travel times were weighted by the inverse of an assigned normalized variance. A normalized standard deviation of one was assigned to the clear arrivals and values up to five were assigned to the others. The residuals were examined, and additional layer boundaries were added, if their inclusion would significantly reduce the residuals. The $P$-wave travel time data were analyzed initially with the set of layer boundaries finally determined for the $S$-wave data. Then, layer boundaries were added if needed and deleted if not needed. Commonly, an additional layer boundary corresponding to the top of the zone of water saturation was needed to fit the $P$-wave data. $P$ - and $S$-wave profiles for all twelve holes are plotted in the Appendix. The upper and lower bounds on the plots show approximate 68 percent confidence limits. The bounds are not symmetrical because they are based on the standard deviations of the slopes of the line segments fit to the travel time data. The slopes are the inverse of velocity. 

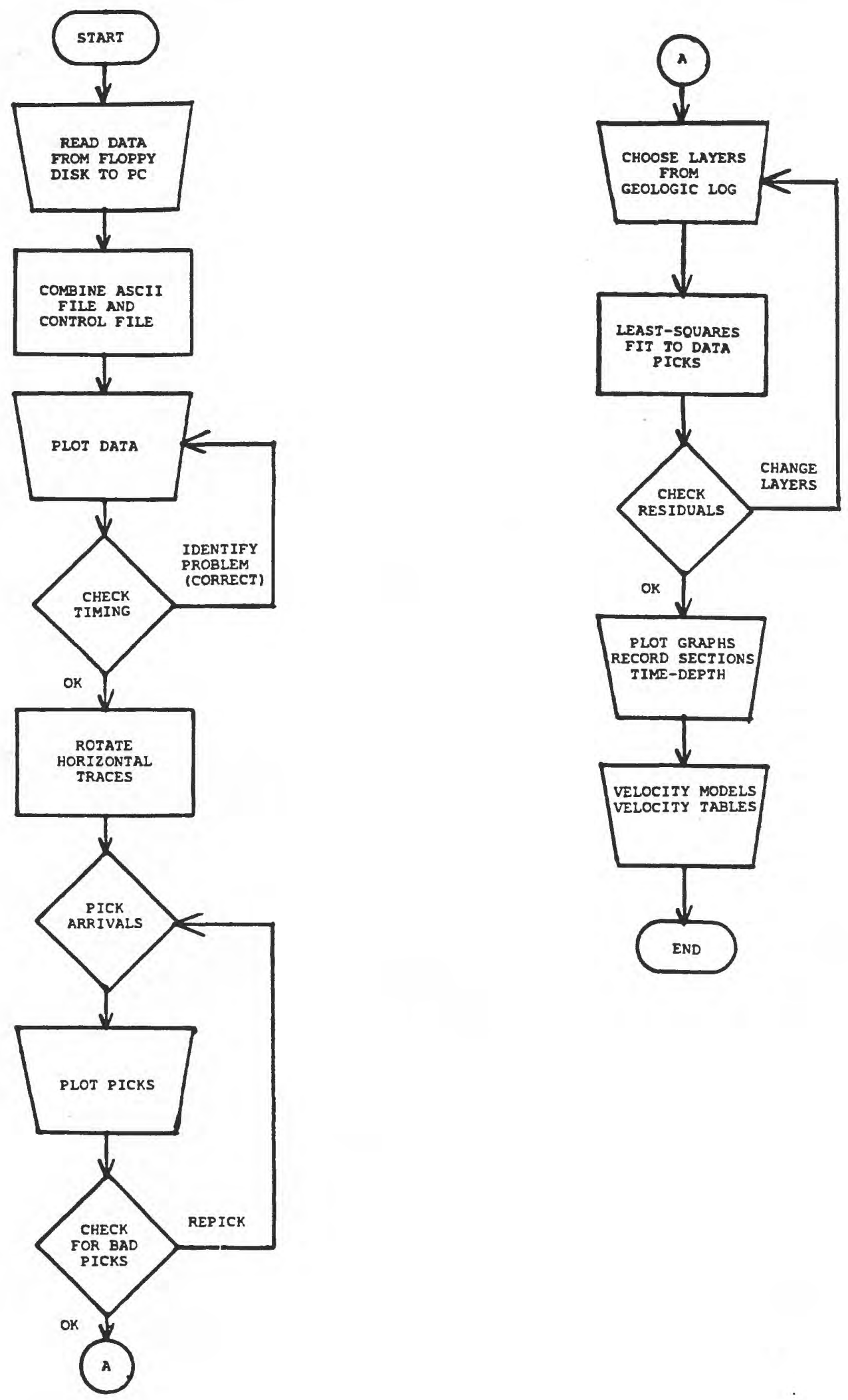

Figure 3. Flow-chart outlining the data processing and steps in the interpretation. 


\section{SUMMARY VELOCITY PROFILES}

Figures 4-6 show the $S$-wave velocity profiles determined from the borehole measurements at the twelve sites. The velocity profiles are plotted at the same scale for ease of comparison. Figures 7-9 show the $P$-wave velocity profiles for the same sites as Figures $4-6$, respectively.

\section{ACKNOWLEDGMENTS}

We are grateful to a large number who made this work possible by helping us gain access to the sites and permission to do the studies. These people include Mrs. Perry C. Norman, Mr. Bob Lancaster, Mr. Ezra Safdie, Mr. Ed Amador and Mr. Robert Bankeser (Sepulveda VA Hospital); Mr. Richard J. Proctor, Mr. Joe Vanderhorst, Mr. Ezell Culver of the Metropolitan Water District of Southern California (Jensen Main Building and Jensen Generator Building sites); Mr. Ron Tognazzini, Mr. Brent Hollingworth, Mr. Don Schauer, Mr. Jeff Owen, and Mr. Craig Davis of the Los Angeles Department of Water and Power (Rinaldi Receiving Station, Sylmar Converter West, and Los Angeles Dam); Mr. Mario Sewell, Mr. Brent McSwain, and Ms. Wendy Wilkinson of the Los Angeles City Recreation and Parks (Sherman Oaks Park); Ms. V. Carlsen and Mr. Robert Lambert (Epiphany Lutheran Church); Ms. Brooke Wolford and Ms. Cindy Trull of the Bank of America and Mr. Frank Adelman (White Oak Church site); Mr. Il Kim, Mr. Ed Teran, Mr. Alphonso Bragg, (Sherman Oaks Woodman); Mr. David Kanthak and Mr. Gary Nottingham of Simi Valley Unified School District (Knolls Elementary School);Dr. Anthony Shakal and Dr. Robert Darragh of California Division of Mines and Geology (Olive View Hospital site); Mr. Ronald Porcella and Mr. Richard Maley of the U.S. Geological Survey (Jensen Main Building, Jensen Generator Building and Sepulveda V.A. Hospital); Prof. Mihailo Trifunac of the University of Southern California (White Oak Church, Epiphany Lutheran Church, and Knolls Elementary School sites).

We also thank Mr. Robert Westerlund and Mr. Joel Johnson of the U.S. Geological Survey for their help with the $S$ - and $P$-wave logging.

Mr. John Singer of the U.S. Geological Survey's Water Resources Division provided drilling and electric logging services at 9 sites; Pitcher Drilling Company of East Palo Alto, California, and Welenco Inc. of Bakersfield, California, provided drilling and electric logging at 3 sites. 


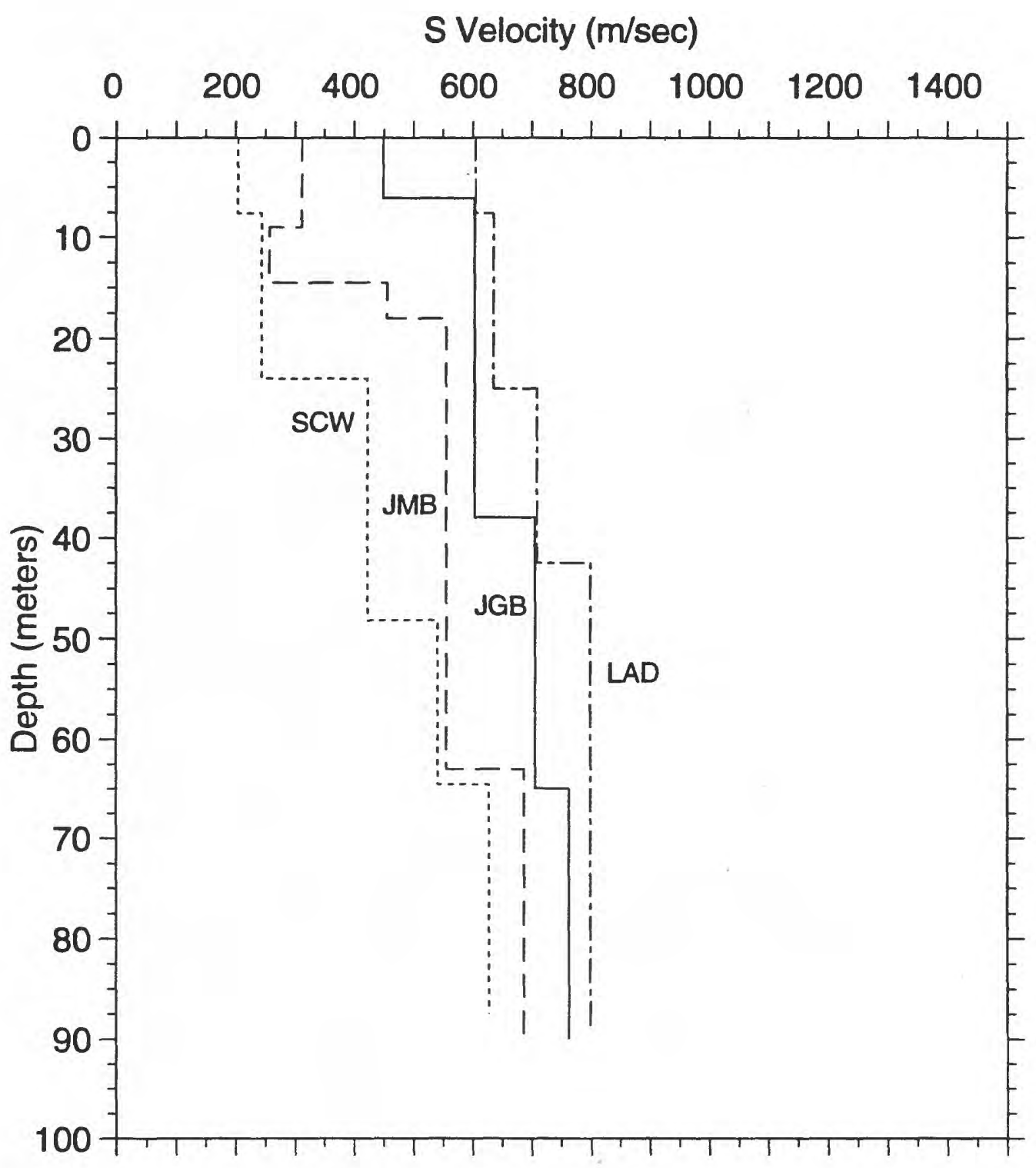

Figure 4. S-wave velocity models shown on the same figure for comparison. Sites JMB, JGB and SCW have various thicknesses of fill and soft Holocene alluvial deposits above the Saugus Formation. LAD is the only site we investigated within the lower (Sunshine Ranch) member of the Saugas Formation. 


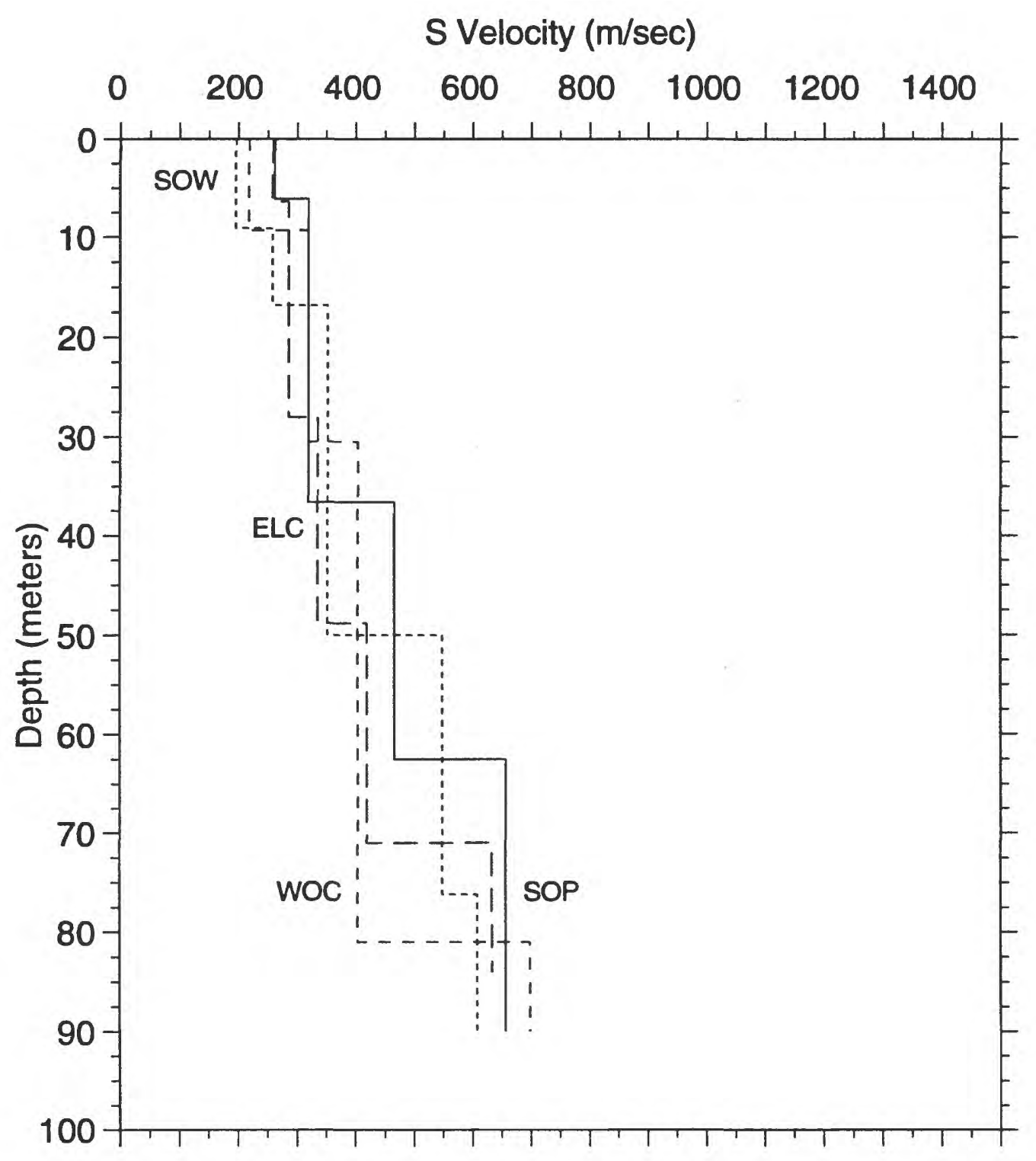

Figure 5. S-wave velocity models shown on the same figure for comparison. These sites all start in relatively soft, fine-textured Holocene alluvial deposits of the Los Angeles River and its tributaries in the San Fernando Valley. Drill holes apparently bottomed in Tertiary marine sedimentary rock (shales, siltstones). 


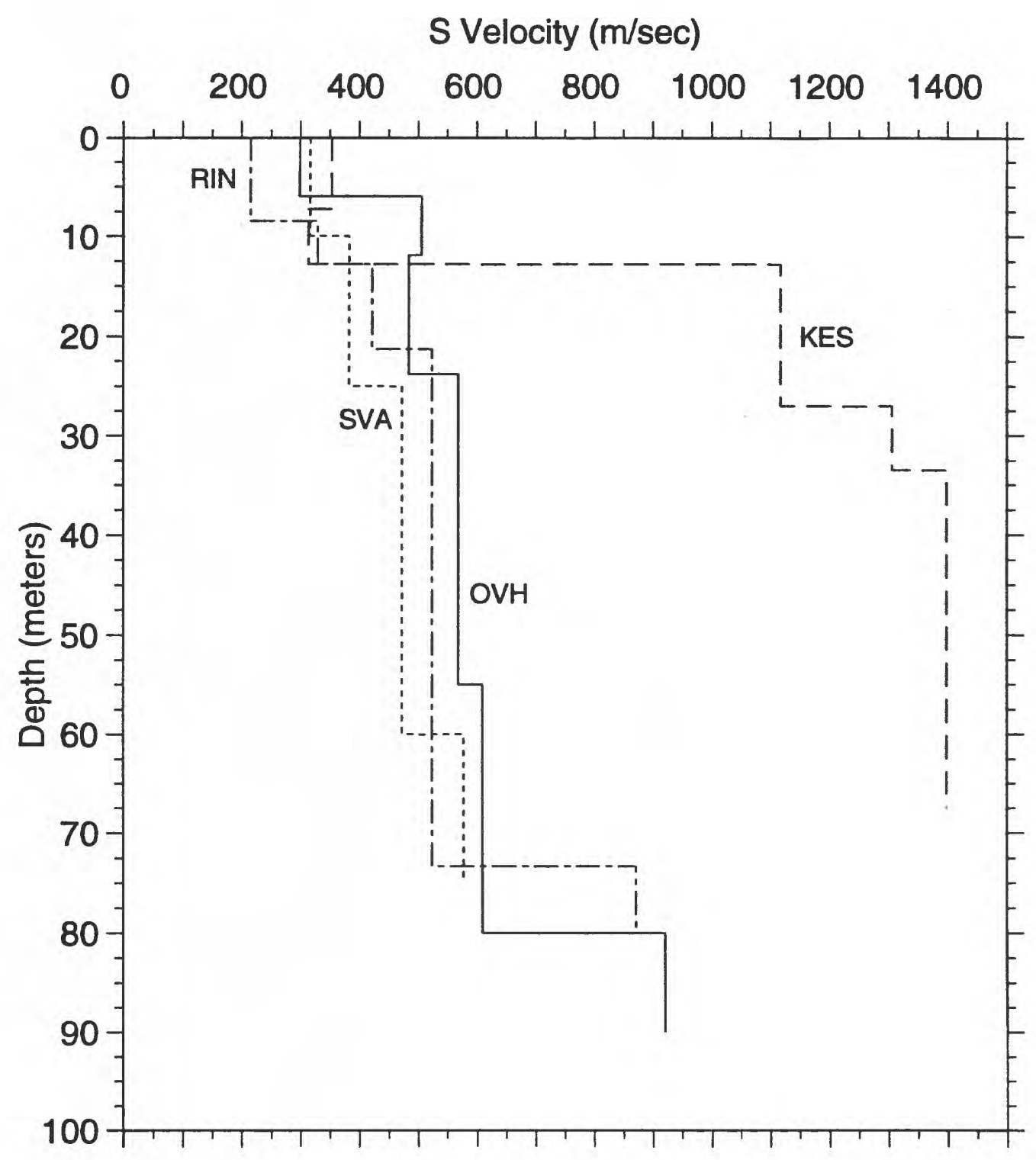

Figure 6. S-wave velocity models for sites, KES, OVH, RIN and SVA. All sites are drilled in sandy or coarser-textured alluvium. At RIN, the drillhole bottomed in marine Tertiary (RIN) mudstone; at KES, in Cretaceous marine sandstone; at OVH and SVA, in nonmarine Saugus(?) Formation or its possible equivalent. 


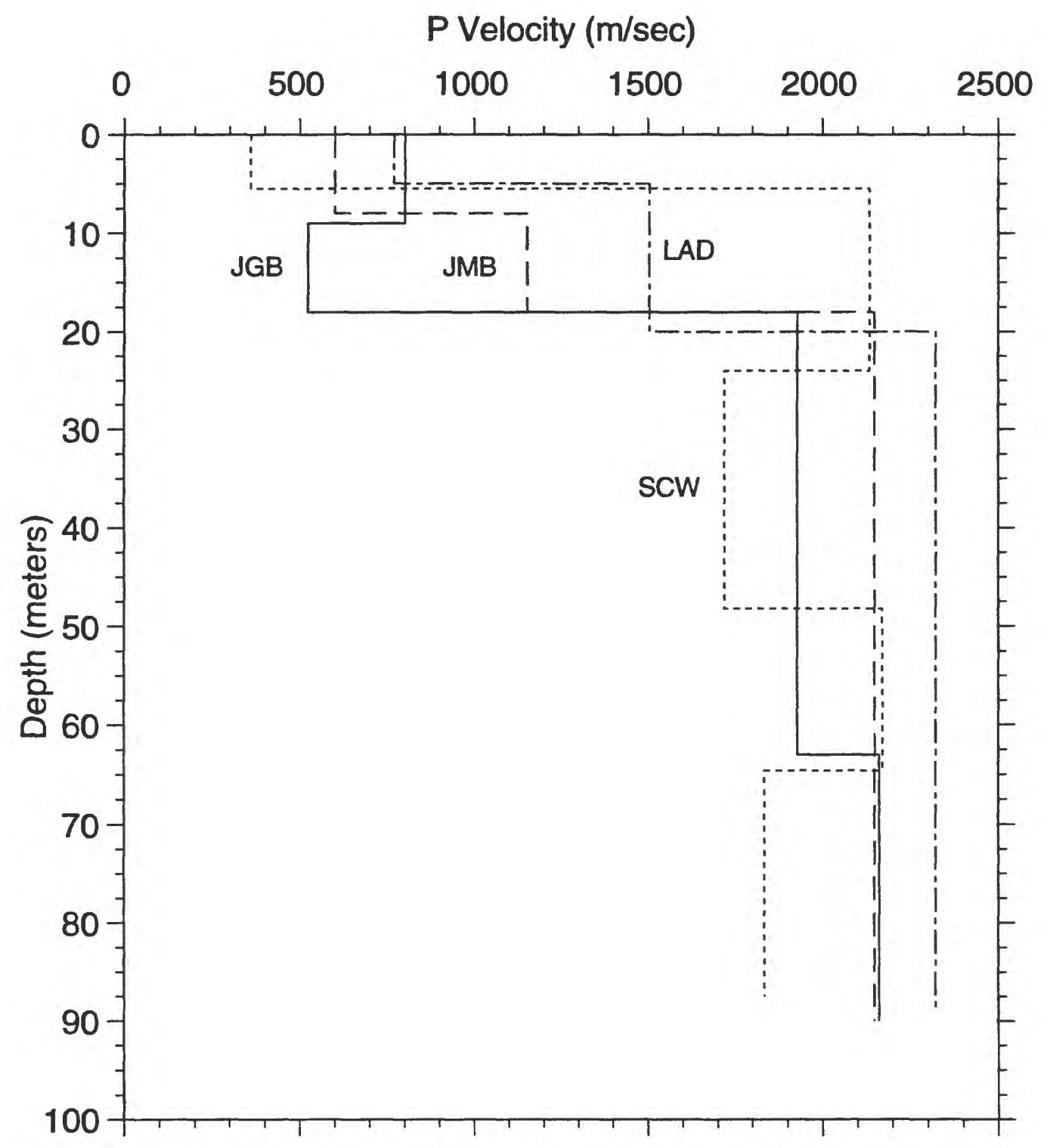

Figure 7. P-wave velocity models shown on the same figure for comparison. 


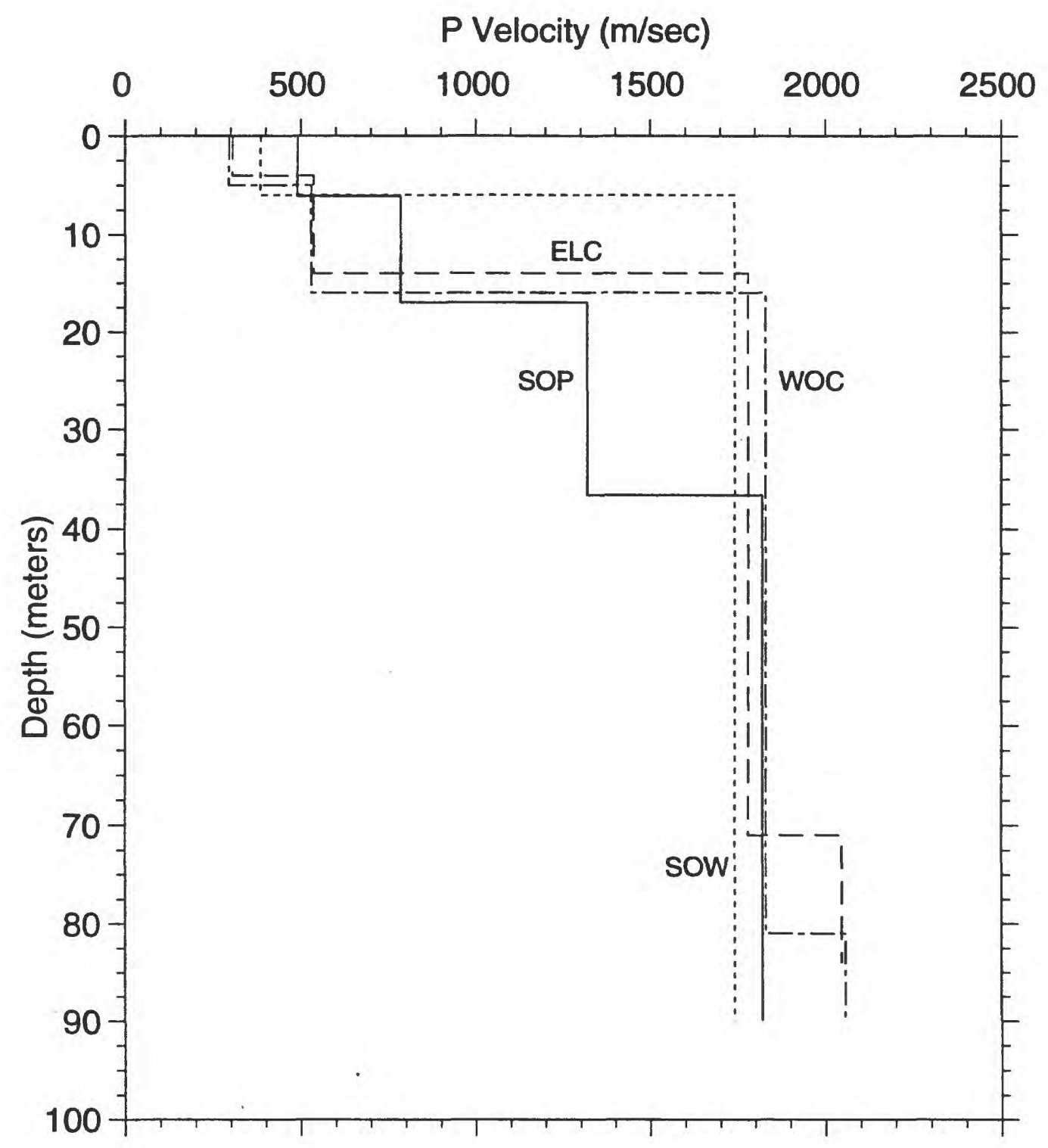

Figure 8. P-wave velocity models shown on the same figure for comparison. 


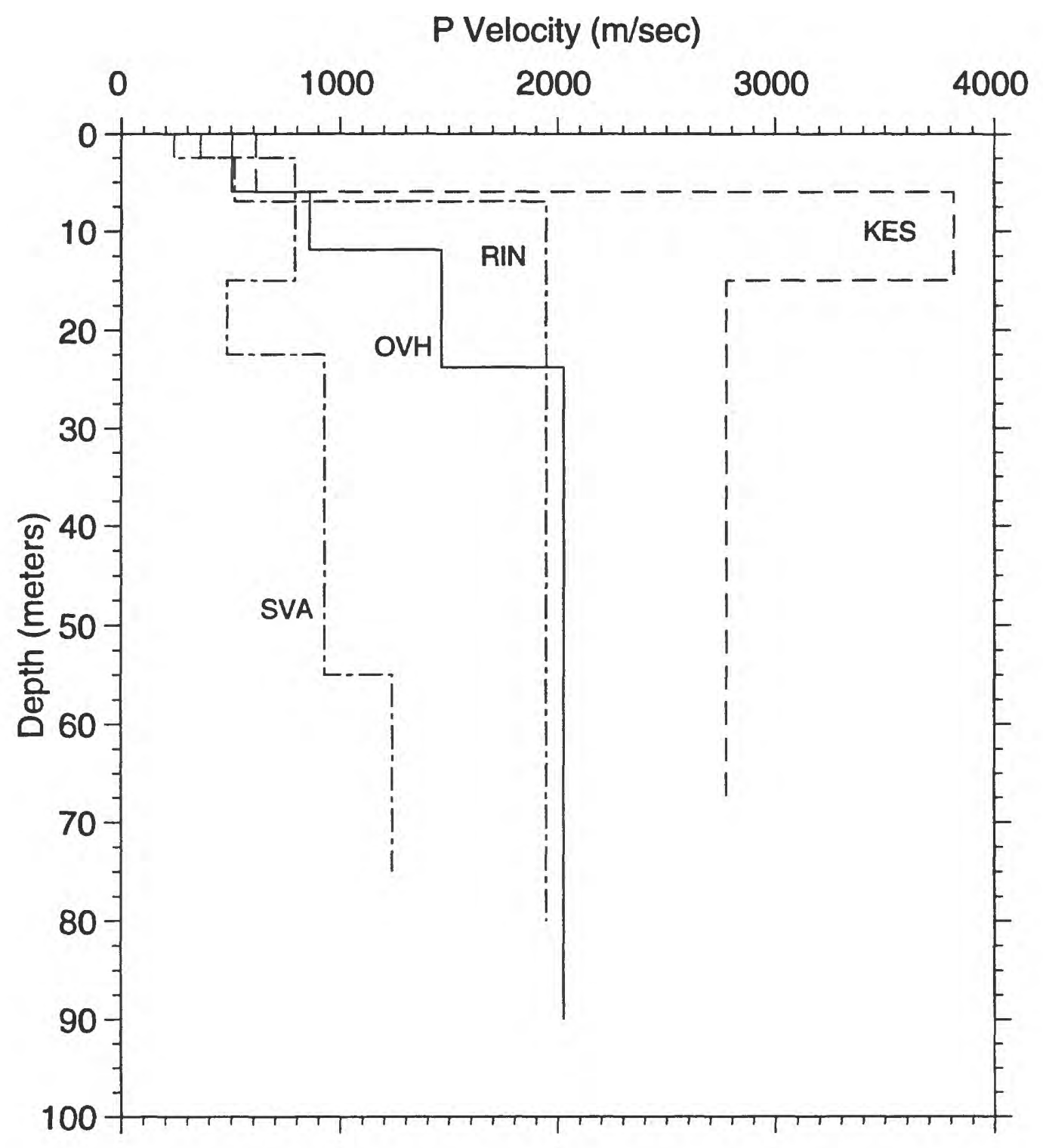

Figure 9. P-wave velocity models shown on the same figure for comparison. 


\section{REFERENCES}

Boatwright, John, Porcella, R., Fumal, T., Liu, Hsi-Ping (1986), Direct estimates of shear wave amplification from a borehole near Coalinga, California: Earthquake Notes, v. 57,p. 8.

Brown, Glenn A. (1975), Ground water geology of the San Fernando Valley in San Fernando, California, Earthquake of February 9, 1971: California Division of Mines and Geology Bulletin 196, p. 31-51.

California State Water Rights Board (1962), Report of Referee, City of San Fernando, California Superior Court, County of Los Angeles, no. 650079: California State Water Rights Board, Text and Plates, v. 1, 258 p.

Jennings, C.W. and Strand, R.G. (1969), Geologic map of California, Los Angeles sheet: Olaf P. Jenkins edition, (scale 1:250000).

King, E.J., Tinsley, J.C. and Preston, R.F. (1981), Map showing historic flooding in the San Fernando Valley, California 1934 to 1956: U.S. Geological Survey, Open-File Report 81 - 153, 5p., 7 plates (scale 1:24000).

Lindvall Richter Benuska (1994), Processed LADWP power system strong- motion records from the Northridge, California Earthquake of January 17, 1994: Los Angeles Division of Water and Power LRB No. 007-027

Liu, Hsi-Ping, Warrick, Richard E., Westerlund, Robert E., Fletcher, Jon B. and Maxwell, Gary L. (1988), An air-powered impulsive shear-wave source with repeatable signals: Bull. Seism. Soc. Am. vol. 78, pp. 355-369.

Oakeshott, G.B. (1950), Geology of the Placerita oil field, Los Angeles County, California: California Journal of Mines and Geology, v. 46, p. 43-80.

Oakeshott, G.B. (1958), Geology and mineral deposits of San Fernando Quadrangle, Los Angeles County, California: California Division of Mines and Geology Bulletin 172, $147 \mathrm{p}$.

Oakeshott, G.B., editor (1975), San Fernando, California, earthquake of 9 Feburary 1971: California Division of Mines and Geology Bulletin 196, Plate 2.

Porcella, R.L., Etheredge, E.C., Maley, R.P., and Acosta, A.V. (1994), Accelerograms recorded at USGS national strong-motion network stations during the MS6.6 Northridge, California earthquake of January 17, 1994: U.S. Geological Survey, OpenFile Report 94 - 141.

Press, William H., Flannery, Brian P., Teukolshy, Saul A. and Vetterling, William T. (1992), Numerical Recipes, the art of scientific computing, Second Edition: Cambridge University Press, Cambridge, p. 668.

Shakal, A., Huang, M., Darragh, R., Cao, T., Sherburne, R., Malhotra, P., Cramer, C., Sydnor, R., Graizer, V., Maldonado, G., Petersen, C. and Wampole, J. (1994), CSMIP strong-motion records from the Northridge, California earthquake of January 17, 1994: California Div. of Mines and Geology, Report No. OSMS 94 - 07.

Tinsley, J.C. and Fumal, T.E. (1985), Mapping Quaternary sedimentary deposits for areal variations in shaking response in Ziony, J.I., ed., Evaluating earthquake hazards in the Los Angeles region, an earth science perspective: U.S. Geological Survey Professional Paper 1360, p. 101-125. 
Tinsley, J.C., Youd, T.L., Perkins, D.M. and Chen, A.T.F. (1985), Evaluating liquefaction potential in Ziony, J.I., ed., Evaluating earthquake hazards in the Los Angeles region, an earth science perspective: U.S. Geological Survey Professional Paper 1360, p. 263315.

Trifunac,M.D., Todorovska, M.I. and Ivanović, S.S. (1994), A note on distribution of uncorrected peak ground accelerations during the Northridge, California, earthquake of 17 January 1994: Soil Dynamics and Earthquake Engineering, vol. IS, pp. 187-196.

Wentworth, C.M. and Yerkes, R.F. and Allen, C.R. (1971), Geologic setting and activity of faults in the San Fernando area, California in The San Fernando, California, earthquake of February 9, 1971: USGS Professional Paper 733, p. 6-16.

Winterer, E.L. and Durham, D.L. (1958), Geologic map of a part of the Ventura basin, Los Angeles County, California: U.S. Geological Survey Oil and Gas Investigations Map OM-196, 1 plate.

Winterer, E.L. and Durham, D.L. (1962), Geology of a part of the southeastern Ventura basin, Los Angeles County, California in Shorter contributions to general geology 1958, U.S. Geological Professional Paper 334-H, p. 275-366.

Yerkes R.F., McCulloh, T.H., Schoellhamer, J.E., and Vedder, J.G. (1965), Geology of the Los Angeles Basin California an introduction: U.S. Geological Survey Professional Paper 420-A, $57 \mathrm{p}$. 


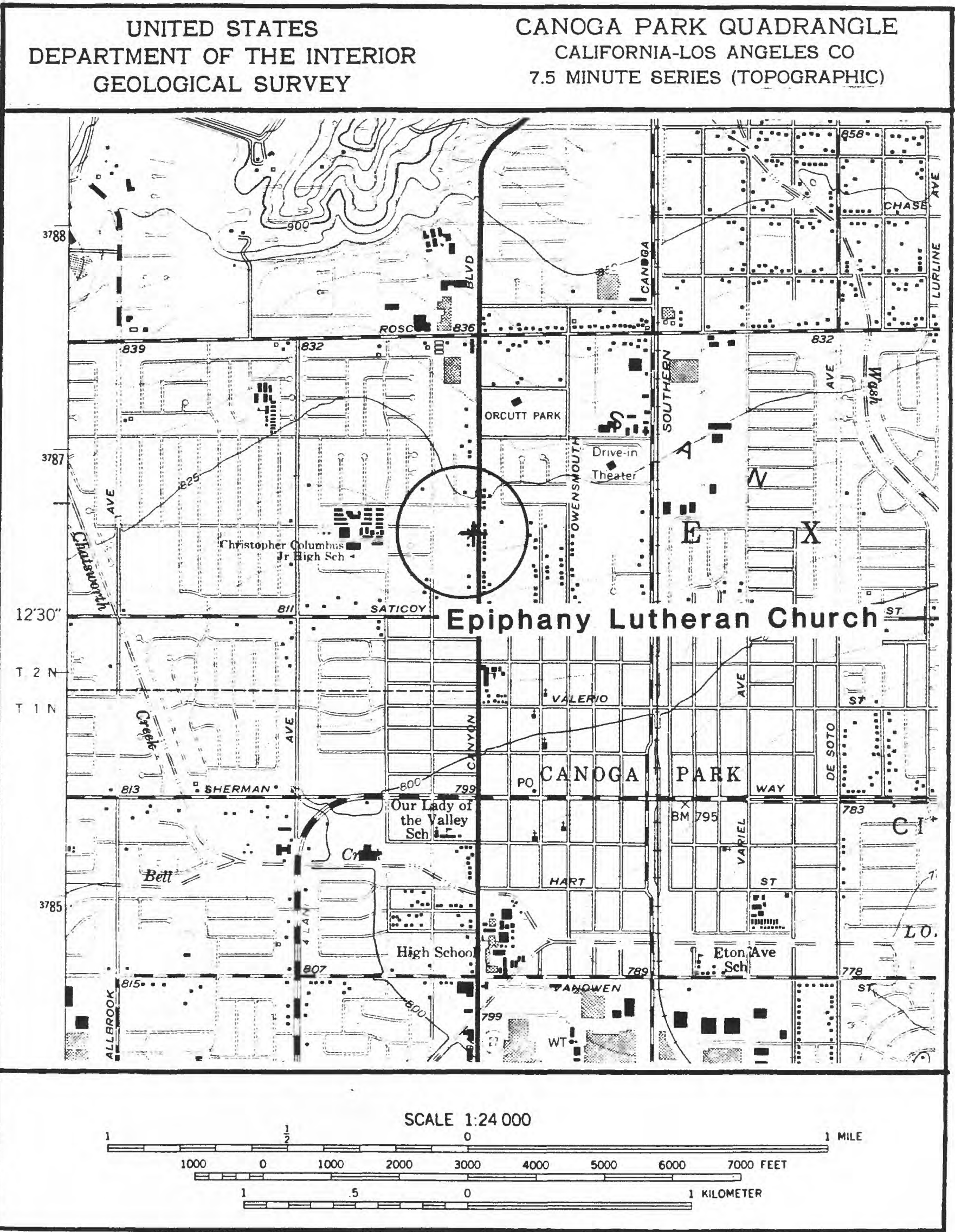

Figure 10. Site location map for the borehole at Epiphany Lutheran Church. The accelerograph is located approximately 50 meters from the borehole. 


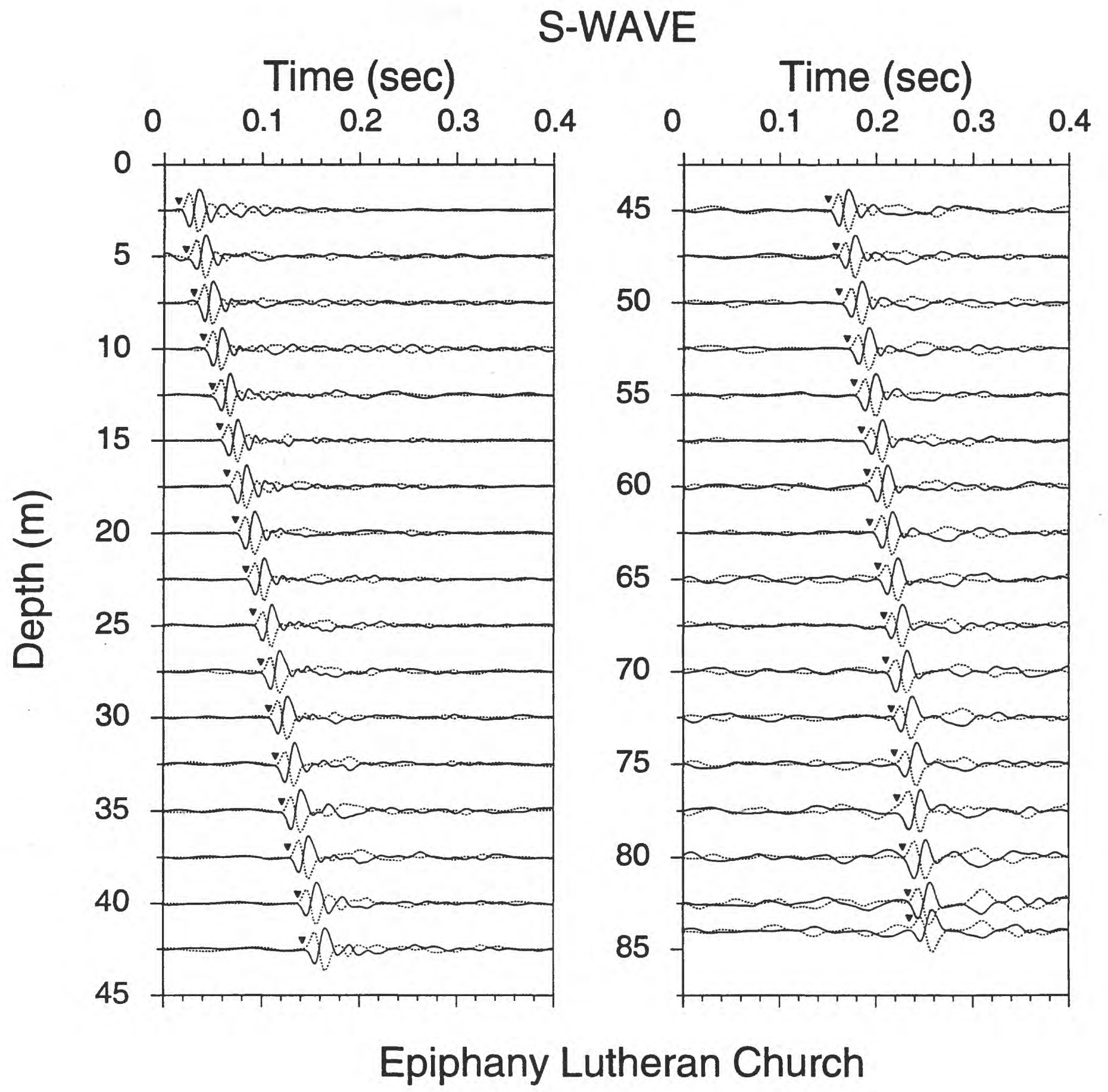

Figure 11. Horizontal component record section (from impacts in opposite directions) superimposed for identification of S-wave onset. Approximate S-wave time picks are indicated by the inverted triangles. 


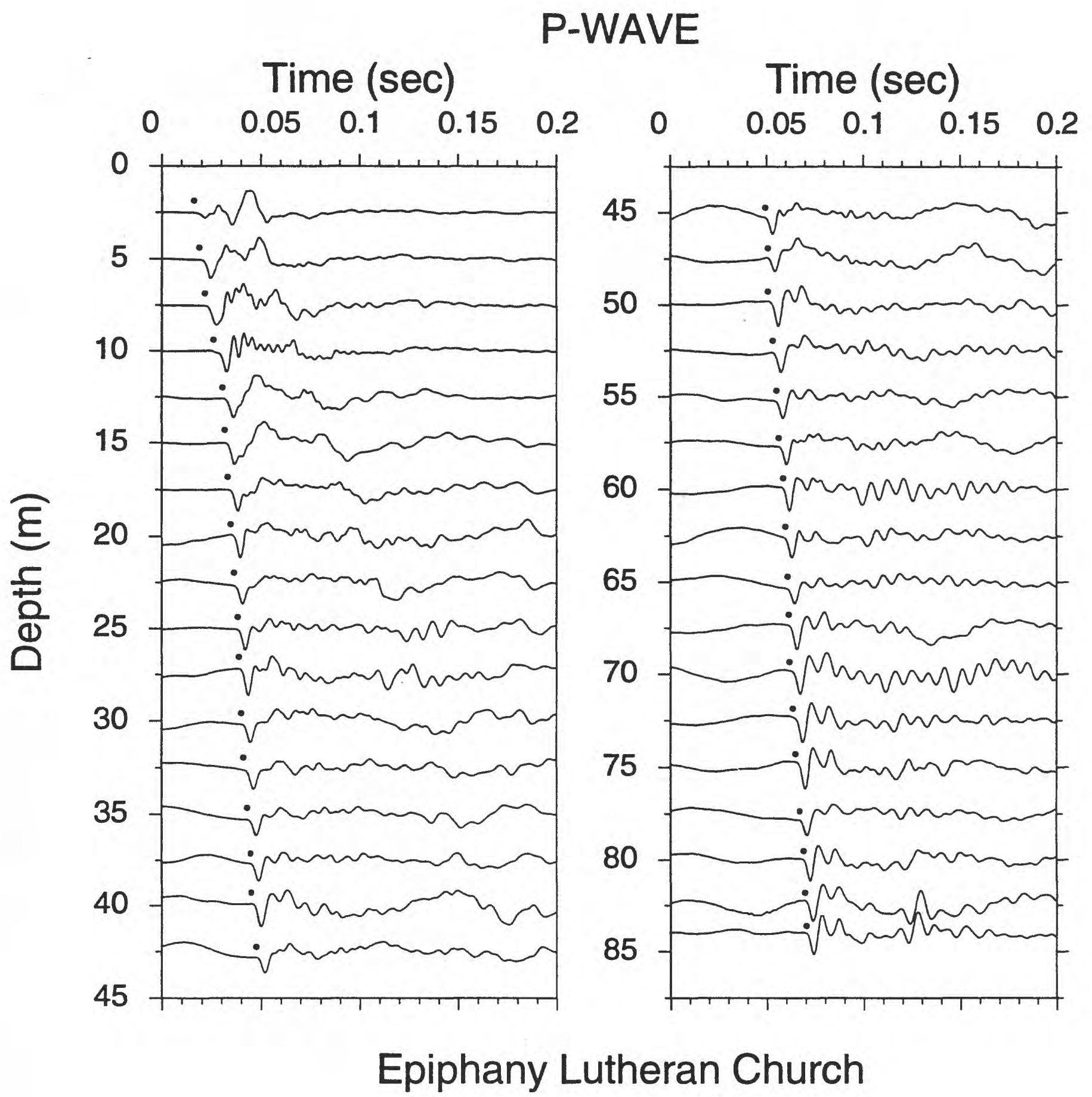

Figure 12. Vertical component record section. P-wave arrivals are indicated by the solid circles. 


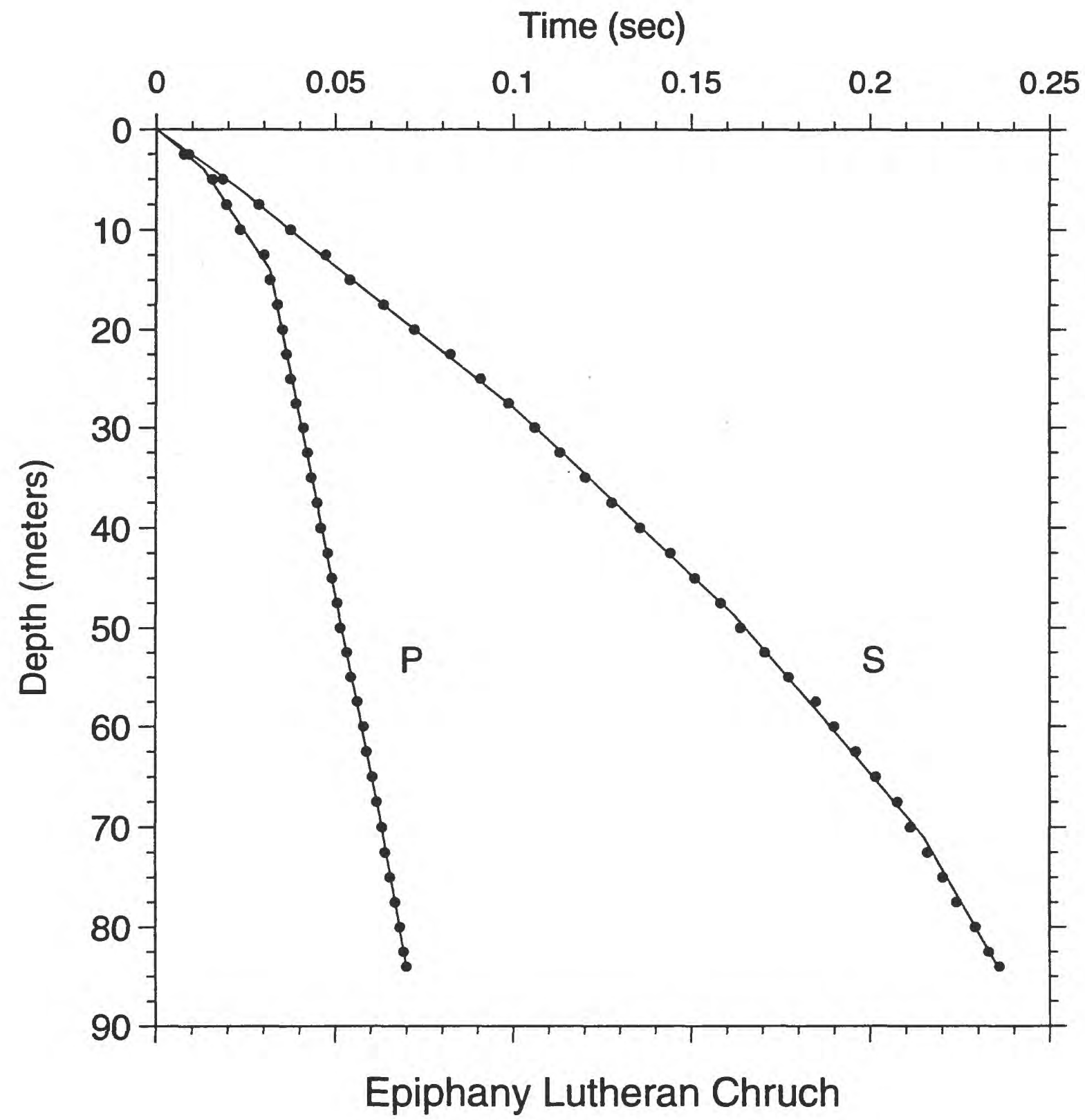

Figure 13. Time-depth graph of $\mathrm{P}$-wave and S-wave picks. Line segments show the hinged-least-squares fit to the data points. 

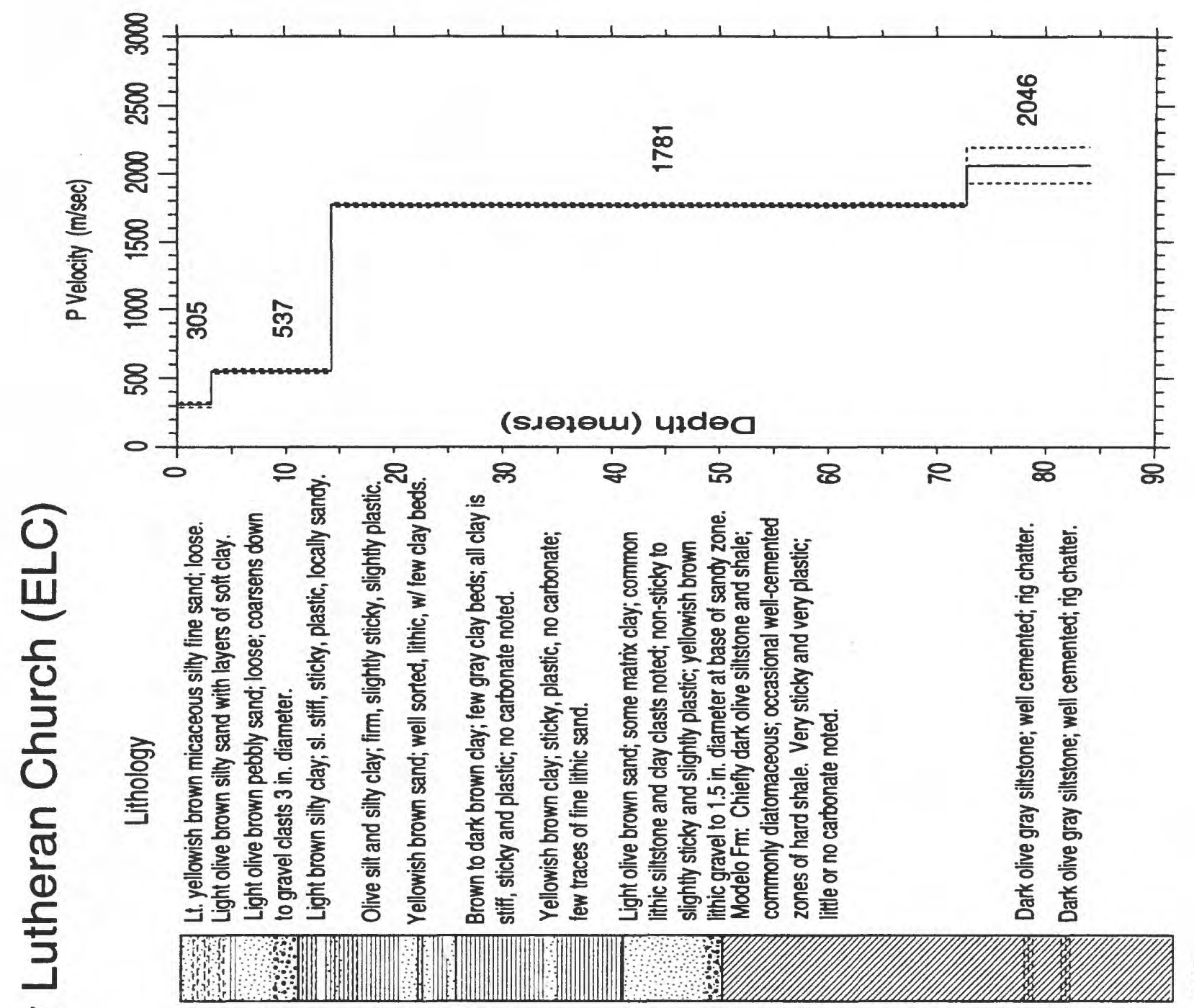

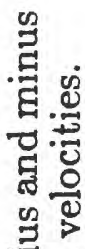

을.

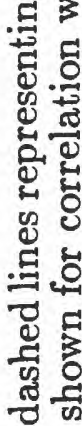

委. 20

30

尊

28

它 愛

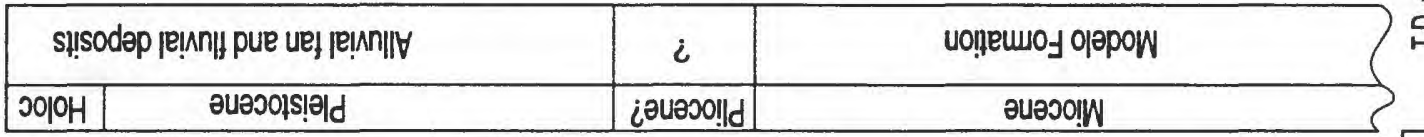

늘

$\circ$ 요 운 \&

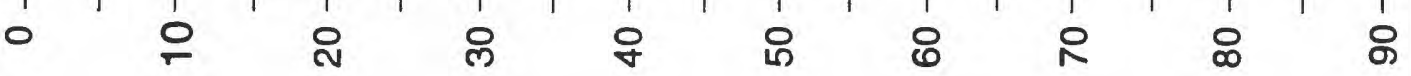

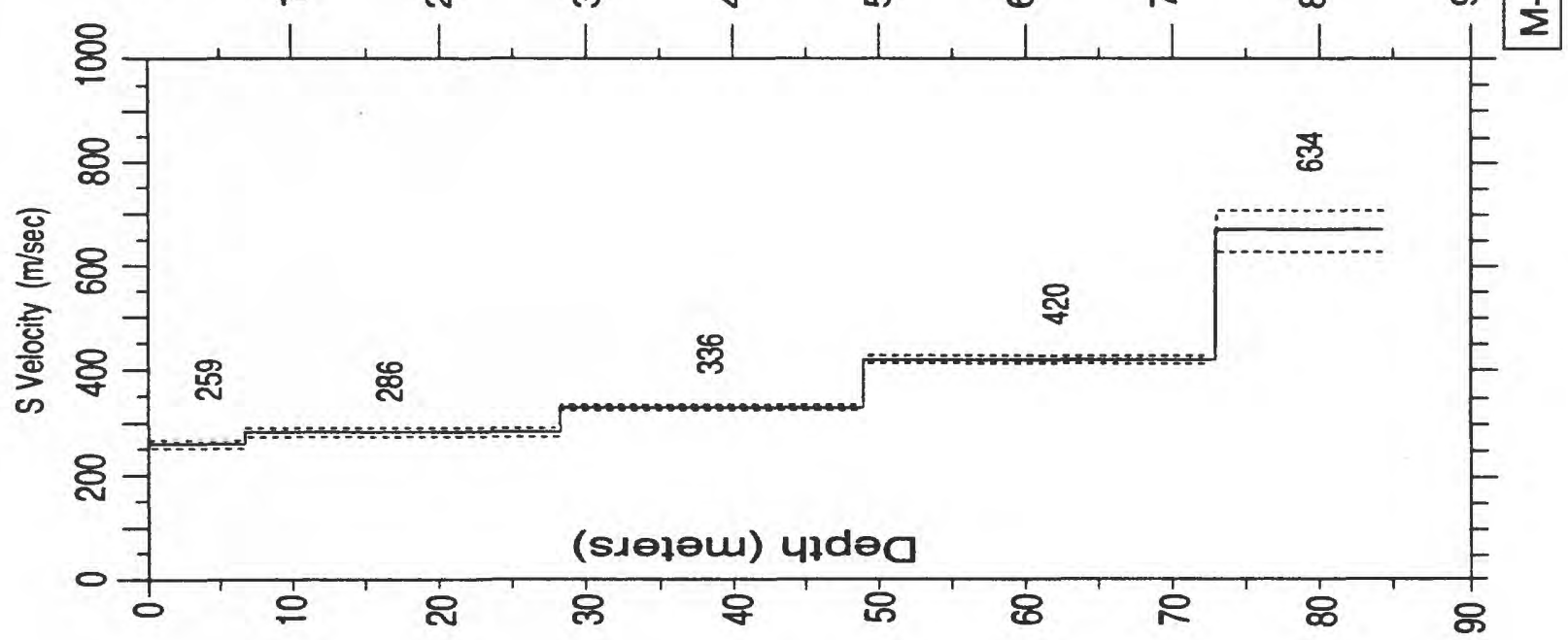

:

更

o

สับ

a

무구

สิ.

के

预

50

[1 


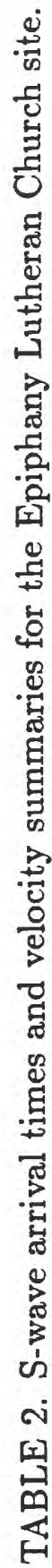

ลูํำำำำกั

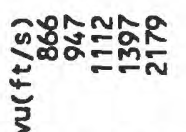

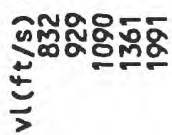

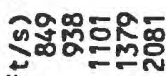

草

zodanom

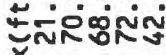

岳

- Doa-ano

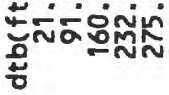

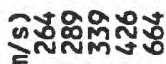

క్

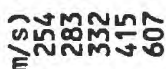

至

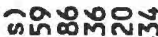

$\cos 0$

Eิธลกักต

aromoo

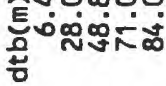

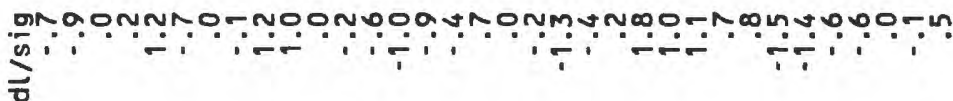

ఫु

010.0.

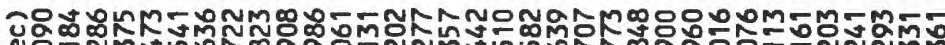

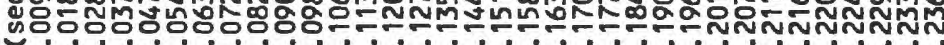

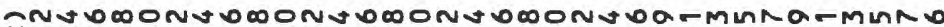
†

Cnomounomonomomomomonomomomonomonomo 落

믕 뭉

政:

要

党热

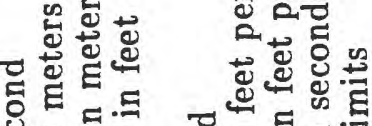
政. .5.

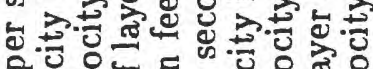

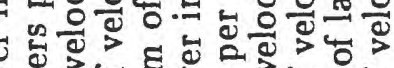

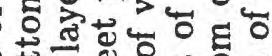
药

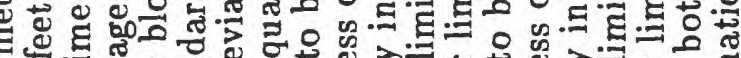

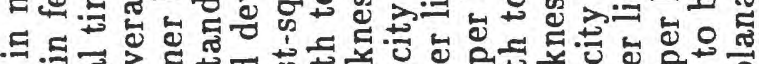

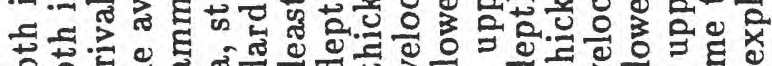
ت

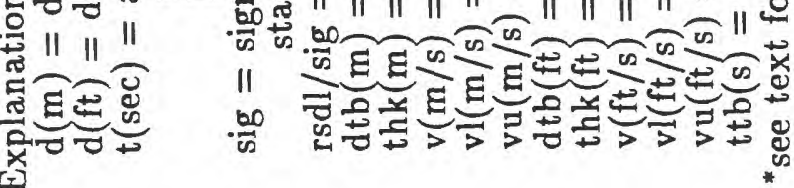


过

\%

당

声

?

承

a

$\stackrel{-1}{+}$

కั)

$\stackrel{\mathscr{c}}{0}$

ฮี

్ㅣㅁ

률

7

ฮี

\&્ఝ

เัตี

圆

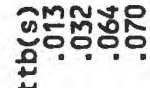

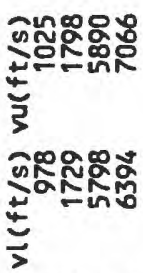

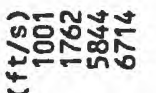

خ

ثีiñ

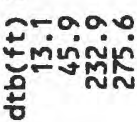

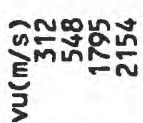

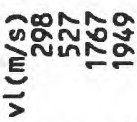

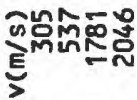

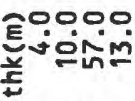

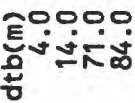

สำ

윤

웡

돌

3 요

형유

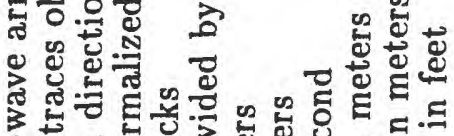

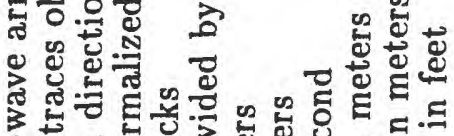

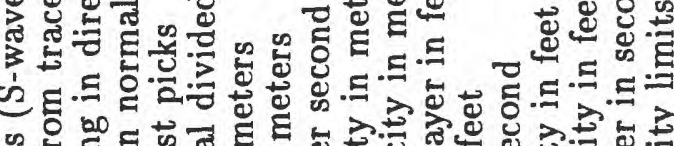

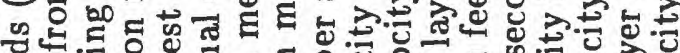

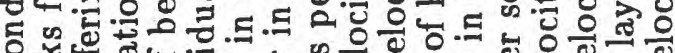

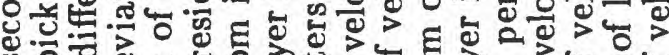

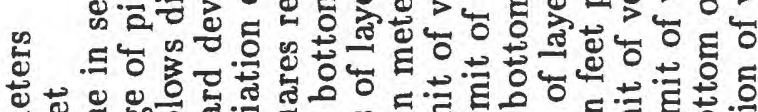
ث艹

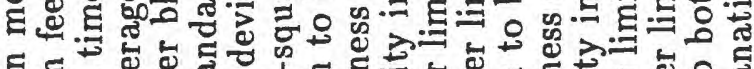

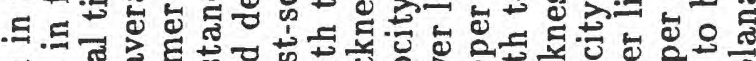

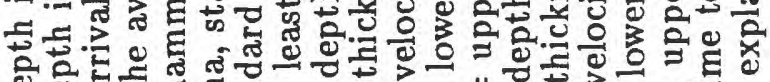

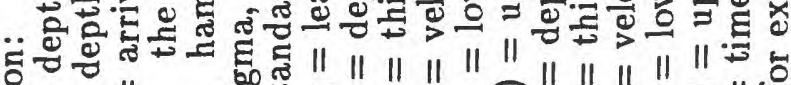

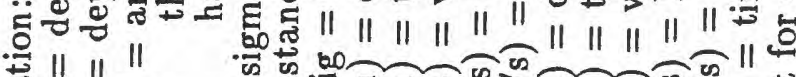

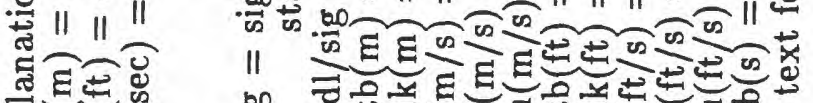

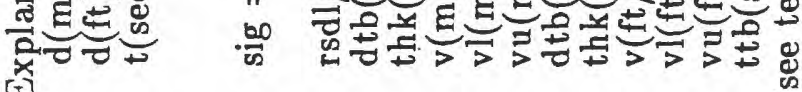

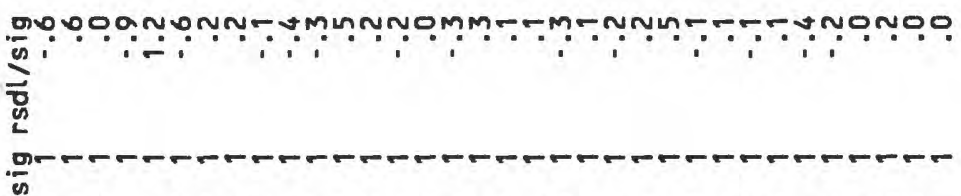




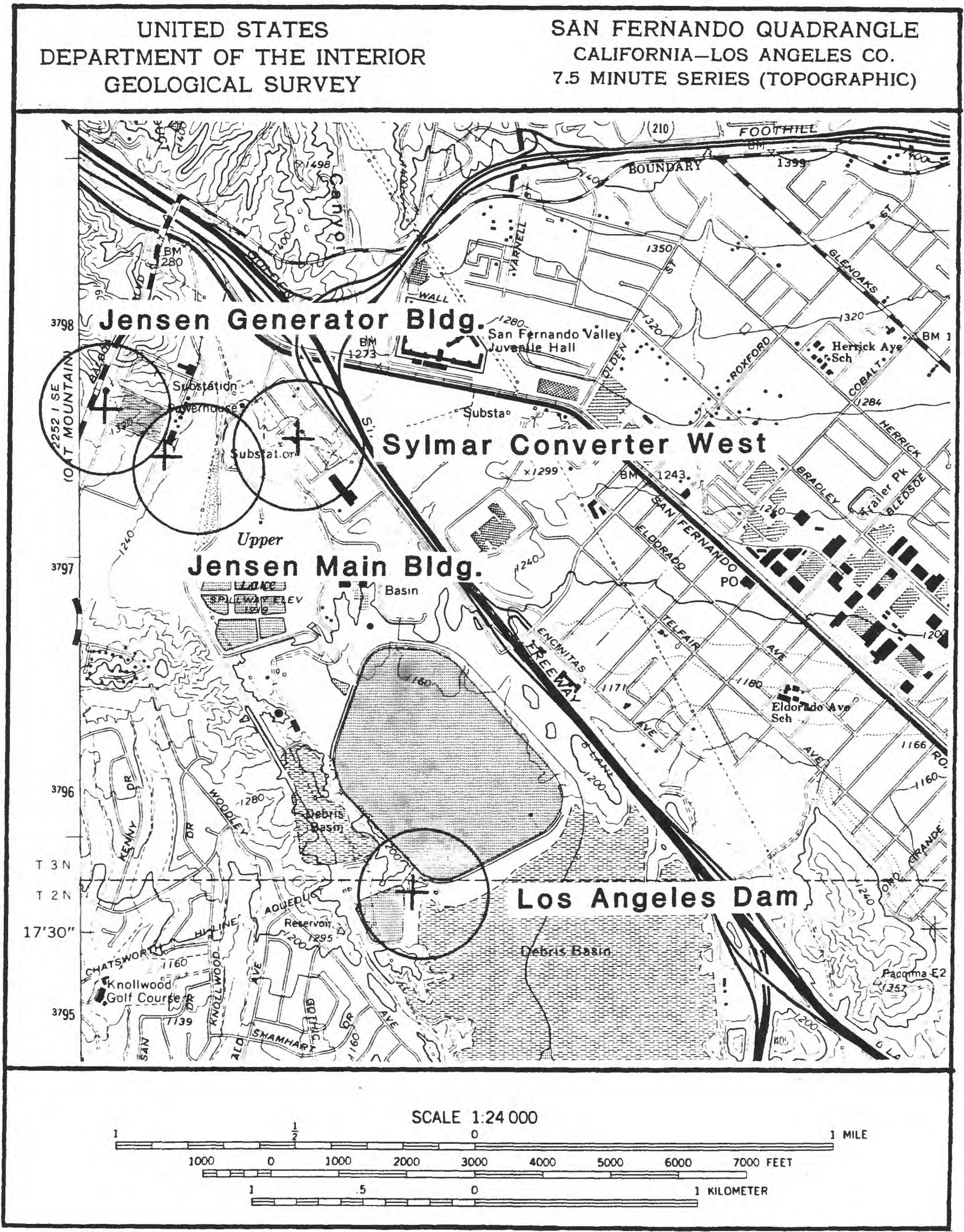

Figure 15. Site location map for the borehole at Jensen Generator Building. The accelerograph is located approximately 25 meters from the borehole. 


\section{S-WAVE}

Time (sec)

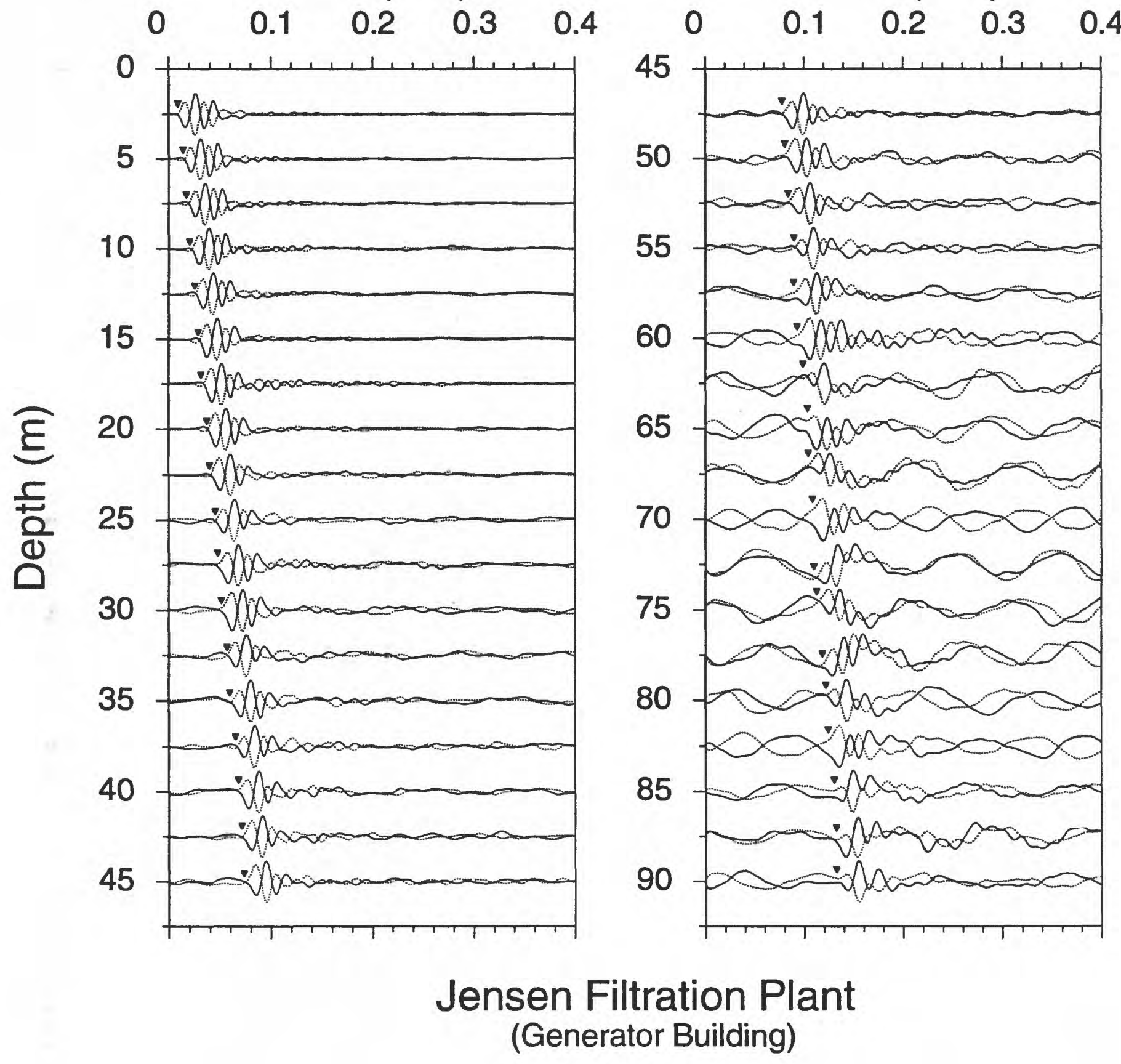

Figure 16. Horizontal component record section (from impacts in opposite directions) superimposed for identification of S-wave onset. Approximate S-wave time picks are indicated by the inverted triangles. 


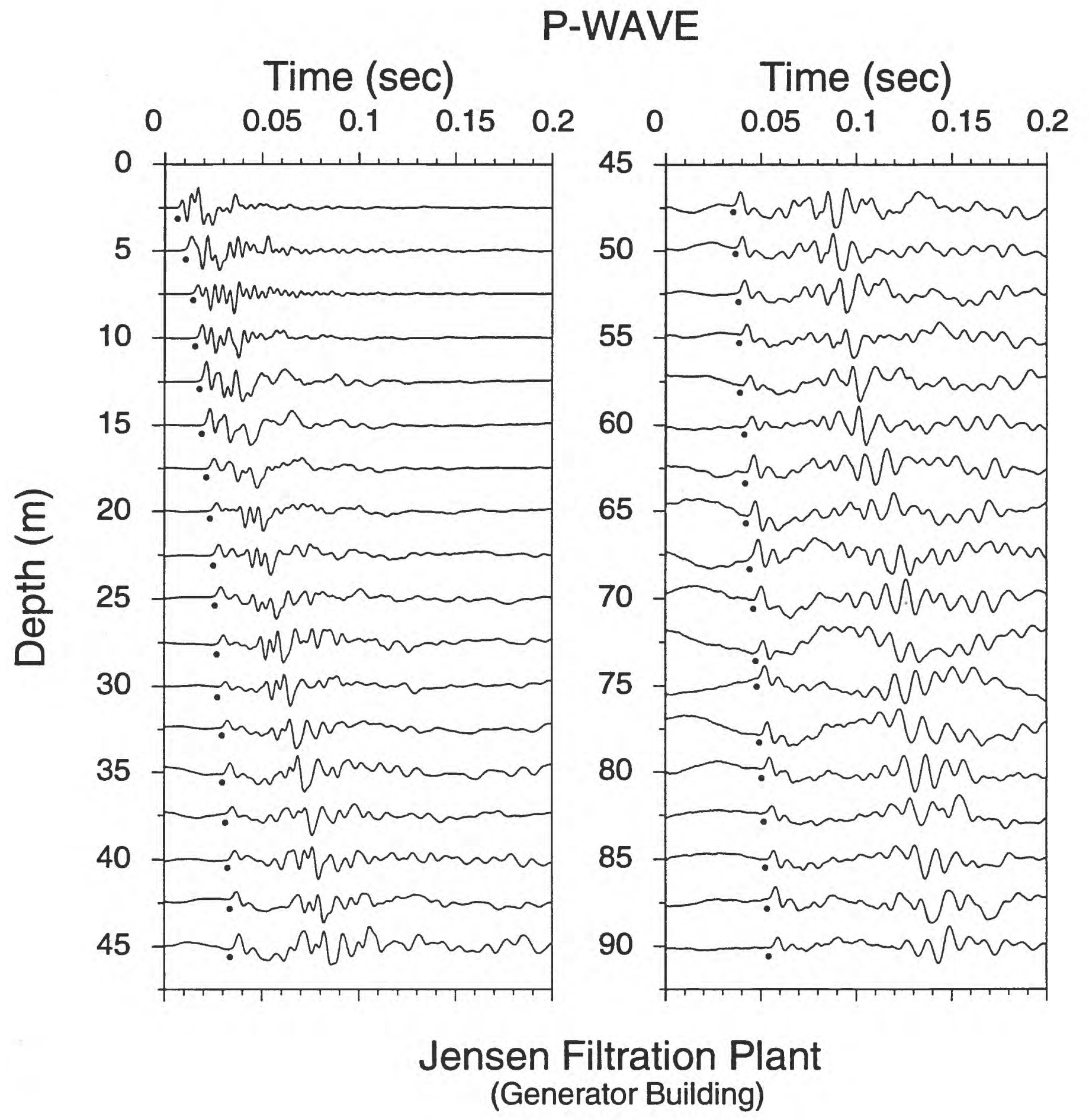

Figure 17. Vertical component record section. P-wave arrivals are indicated by the solid circles. 


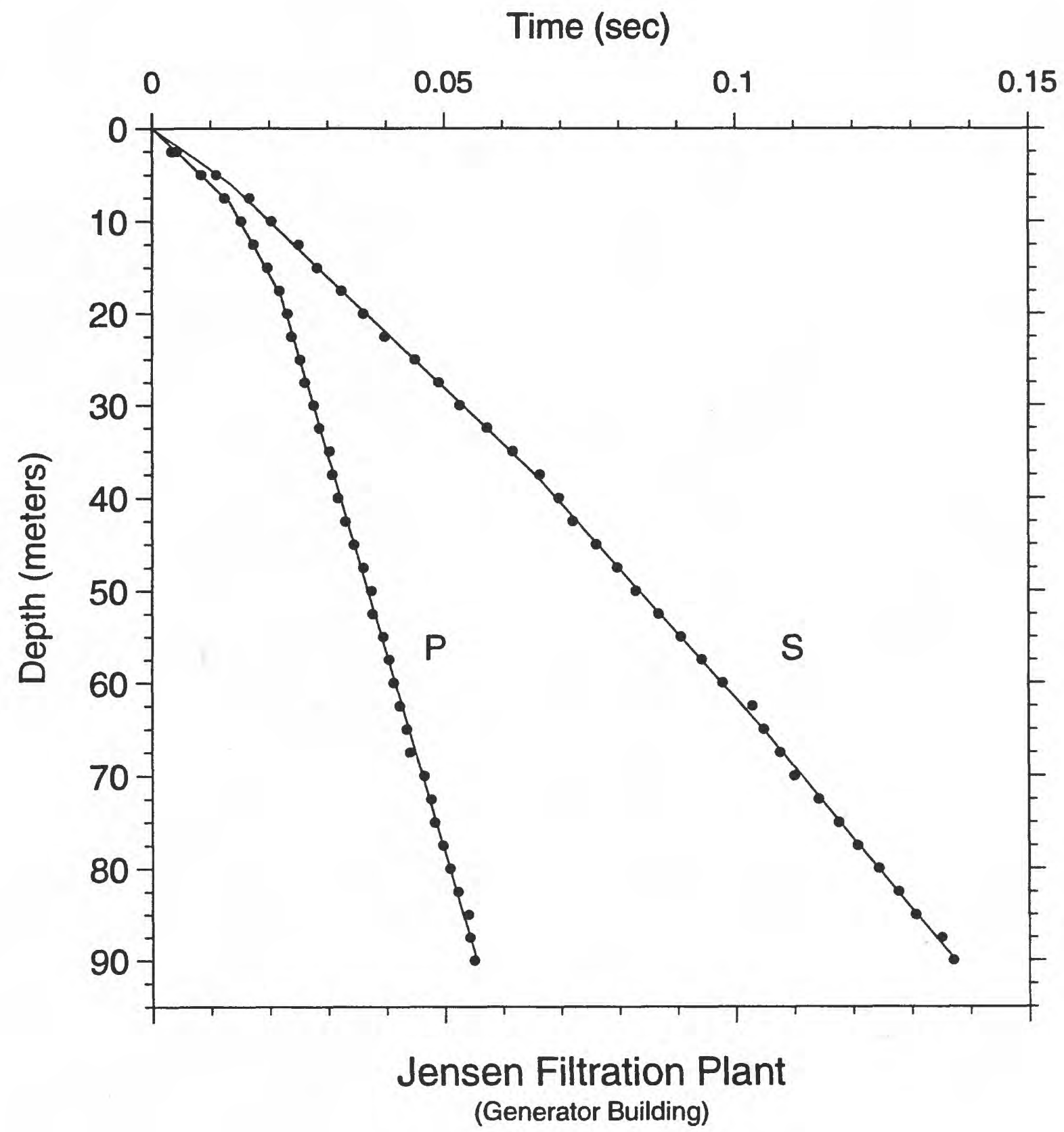

Figure 18. Time-depth graph of $\mathrm{P}$-wave and S-wave picks. Line segments show the hinged-least-squares fit to the data points. 


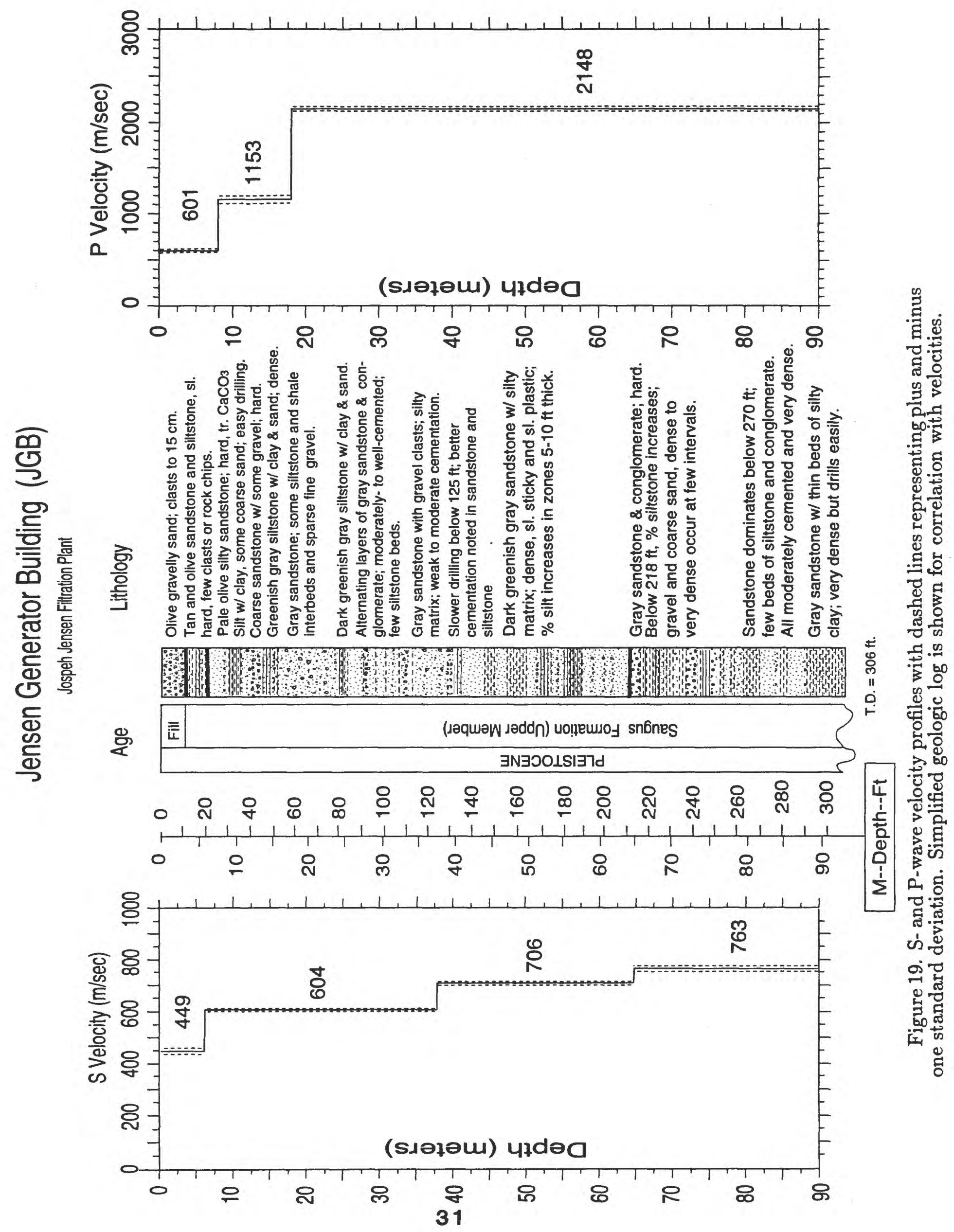


ปั

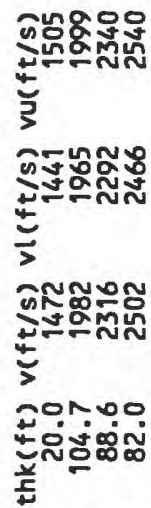

\& 윤응

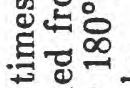

तี

2 .

는유월

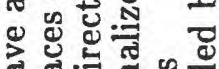

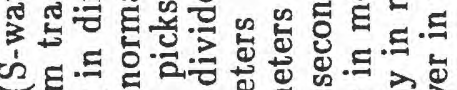

*ํํㄹ

过

넘

里

里

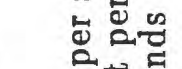

닝

$\Phi \notin$

थ

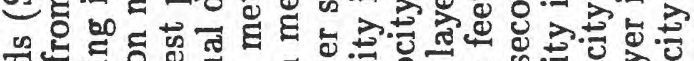

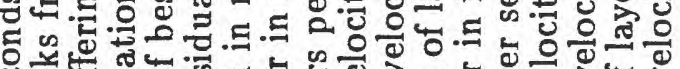

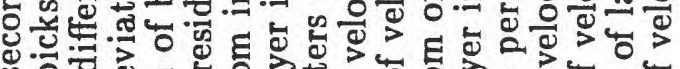

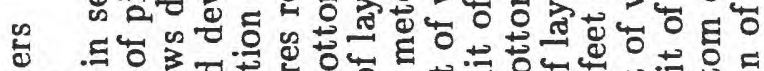

CONmm

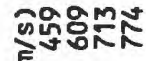

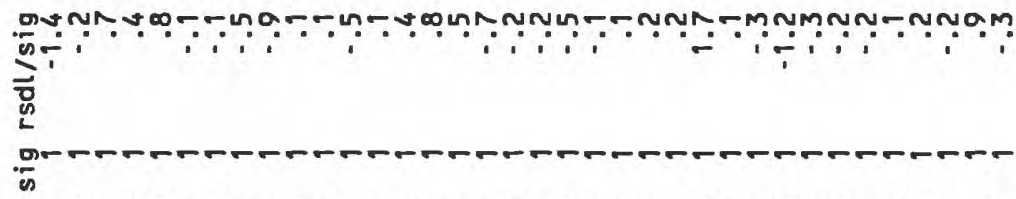

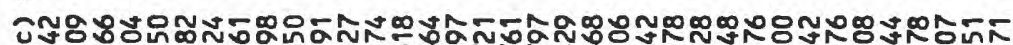

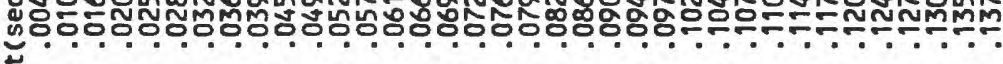

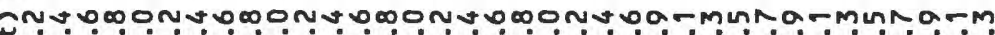

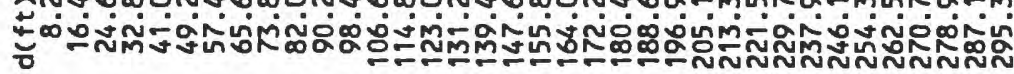

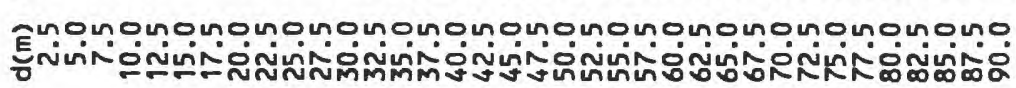




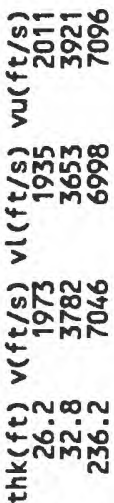

$\frac{1}{6}$

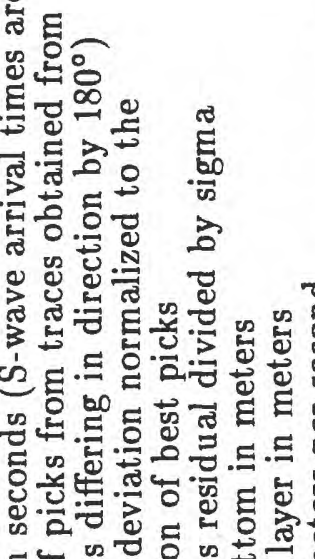

* 릉

एँ

$\infty$

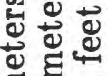

래드

릉 드.

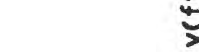
क มกำ?

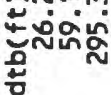

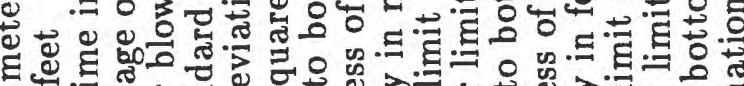
트든

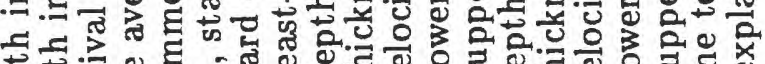

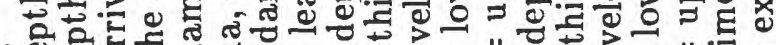

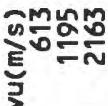
$\because$ 응 능

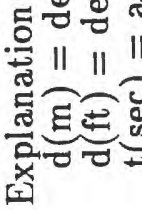
.

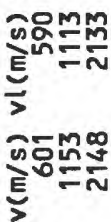

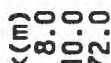
帝

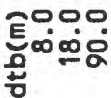

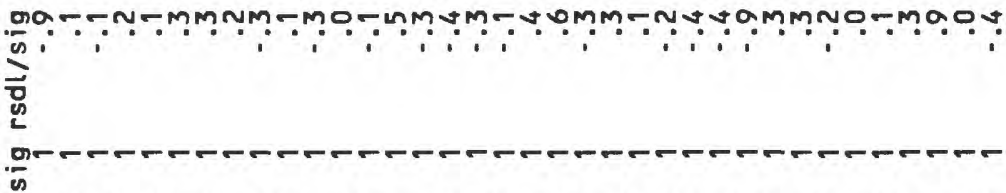

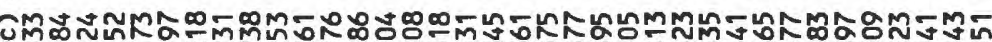

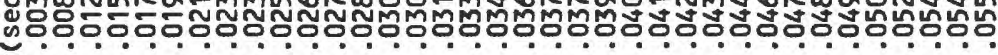

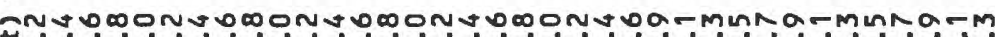

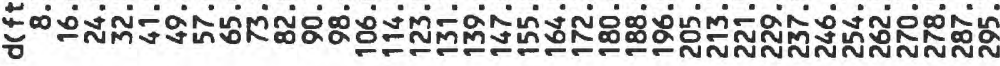

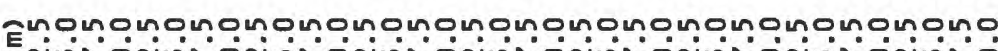
Eัก 


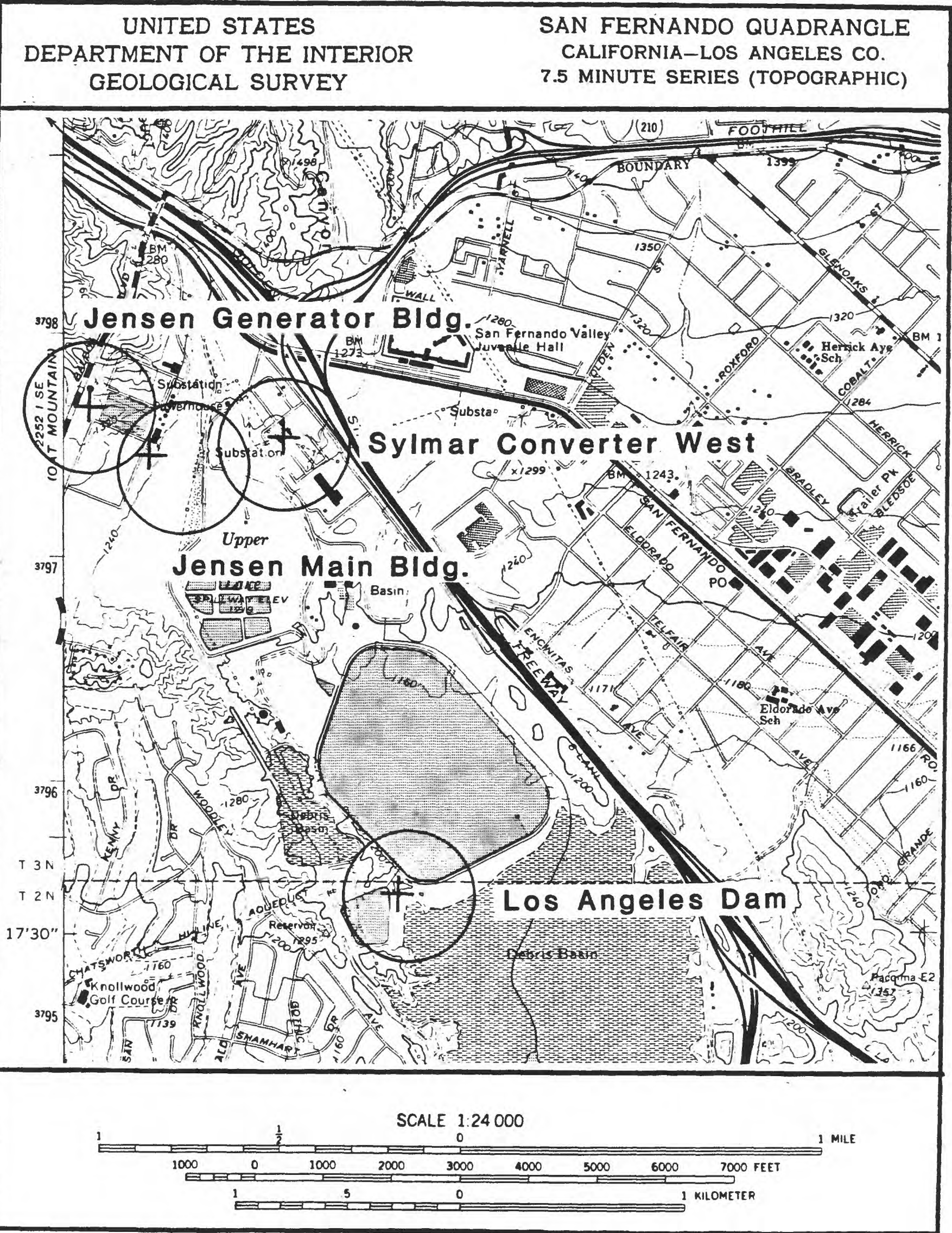

Figure 20. Site location map for the borehole at Jensen Main Building. The accelerograph is located approximately 40 meters from the borehole. 


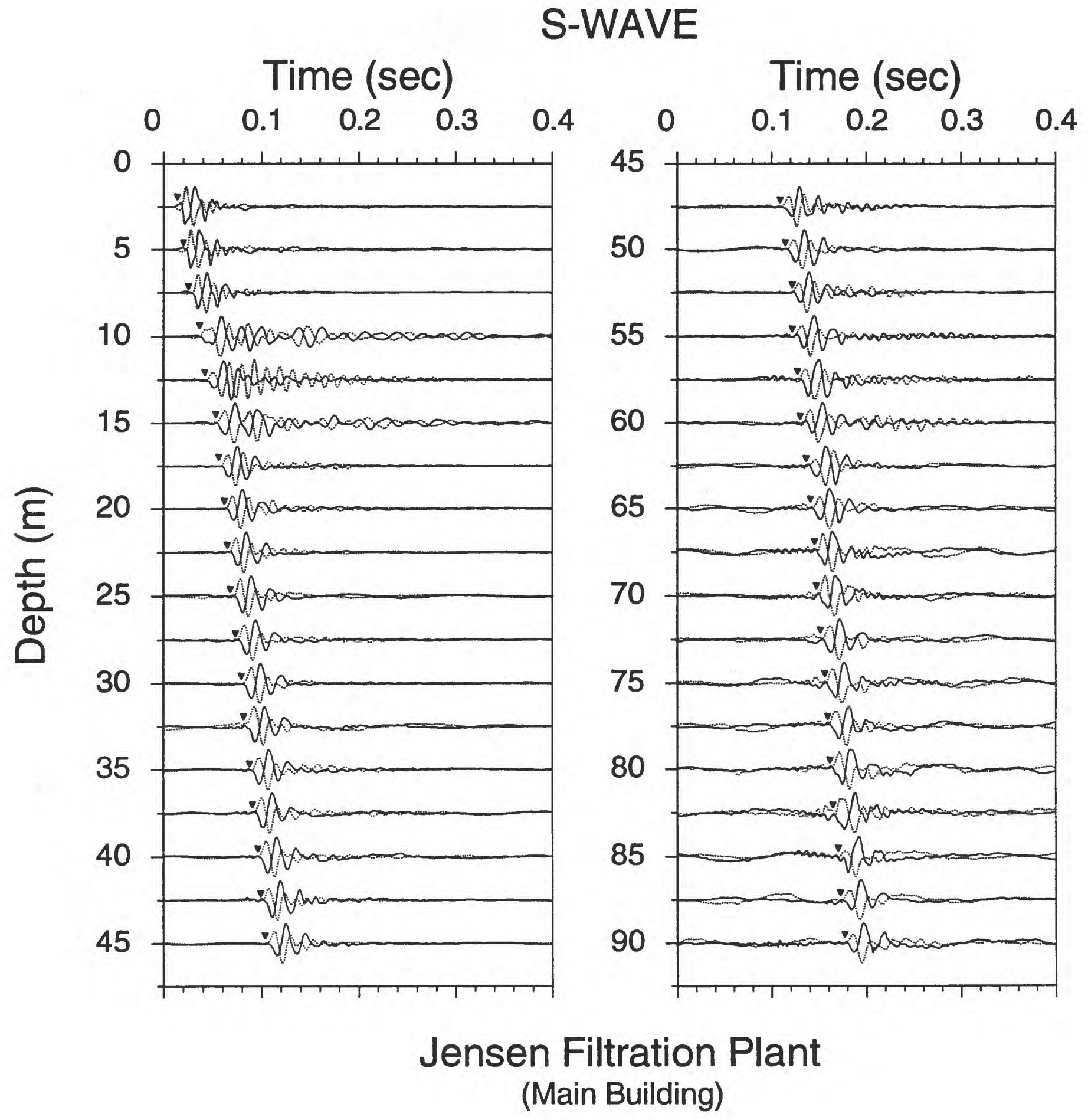

Figure 21. Horizontal component record section (from impacts in opposite directions) superimposed for identification of S-wave onset. Approximate S-wave time picks are indicated by the inverted triangles. 


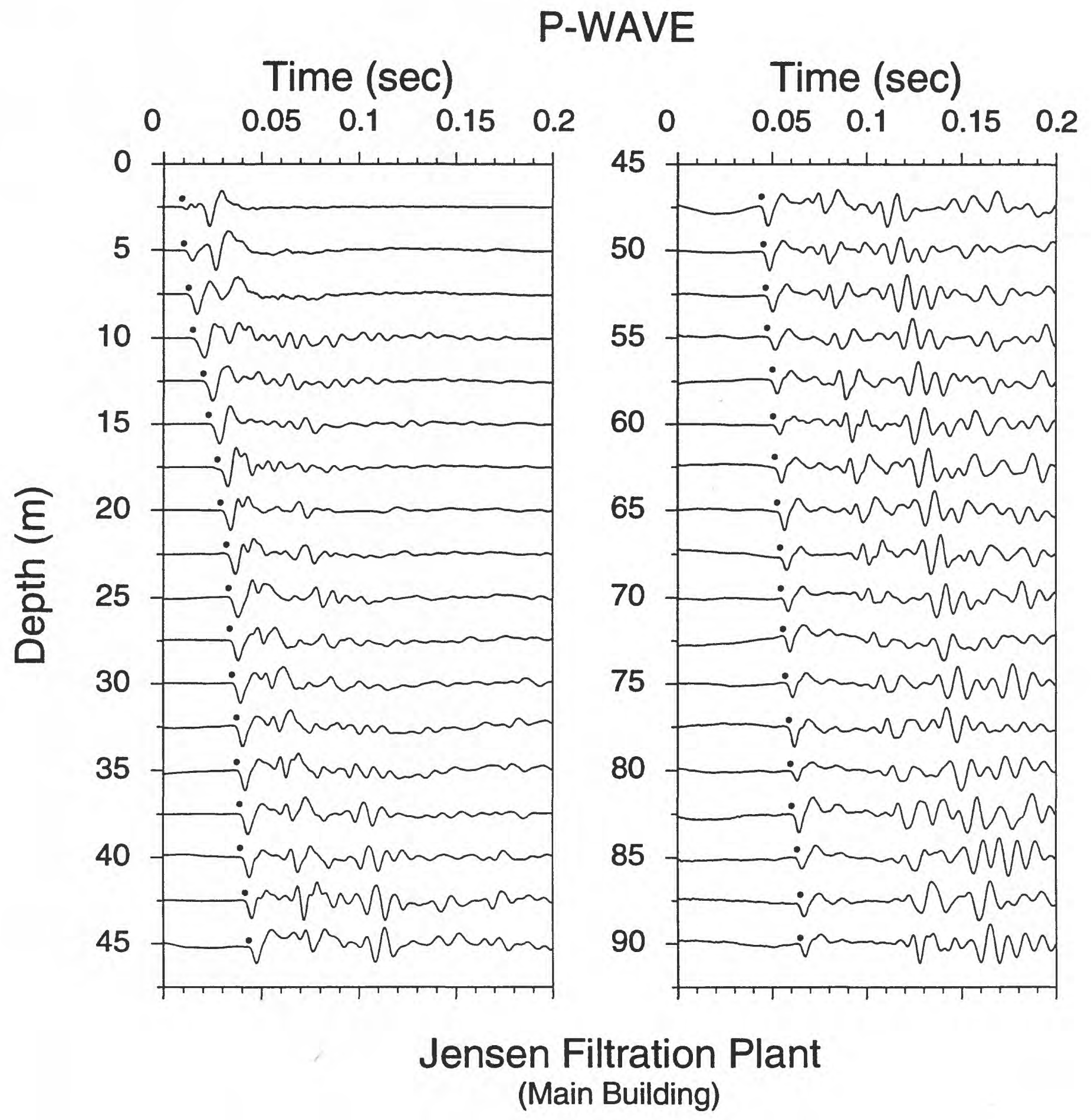

Figure 22. Vertical component record section. P-wave arrivals are indicated by the solid circles. 


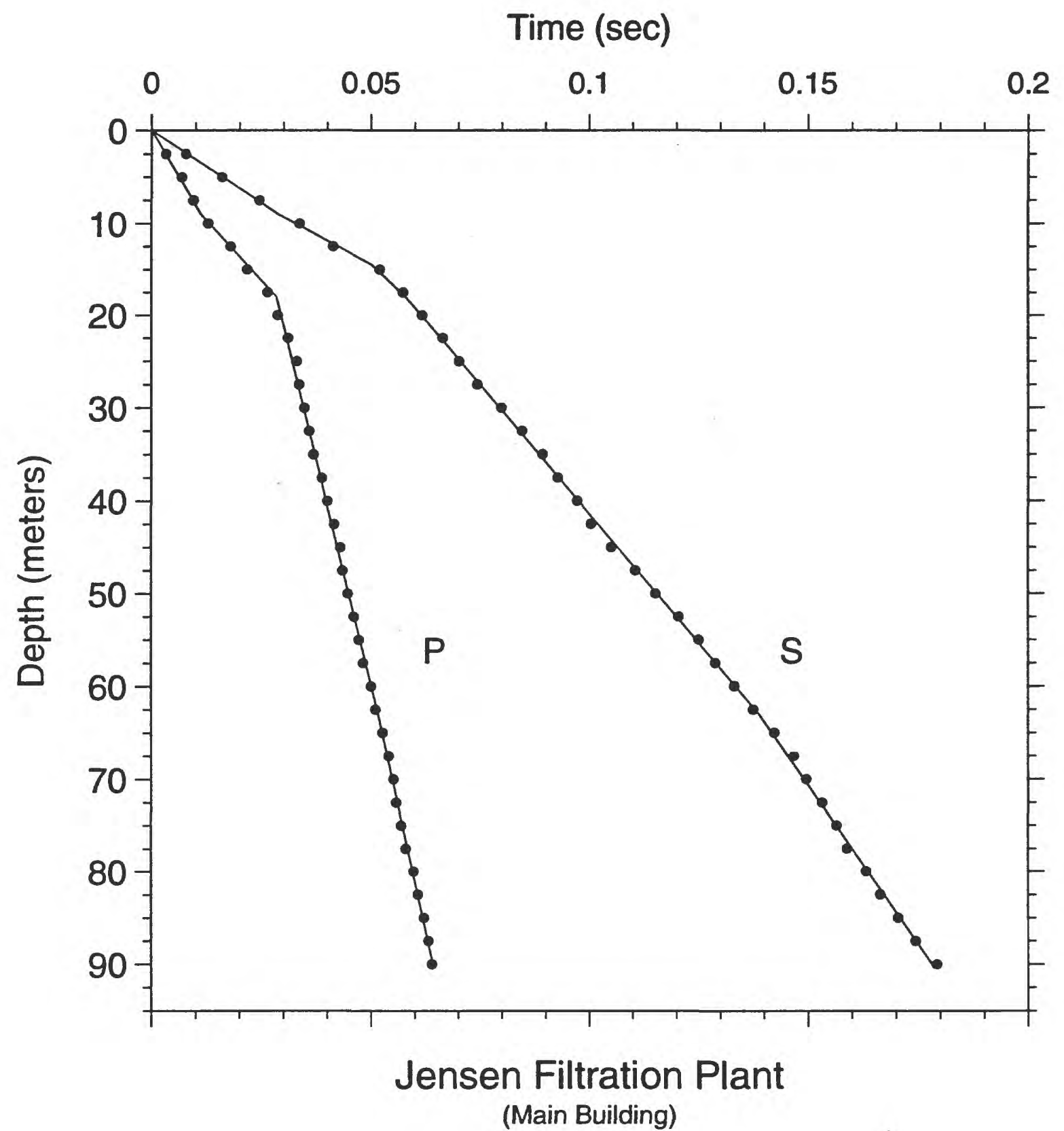

Figure 23. Time-depth graph of $\mathrm{P}$-wave and S-wave picks. Line segments show the hinged-least-squares fit to the data points. 


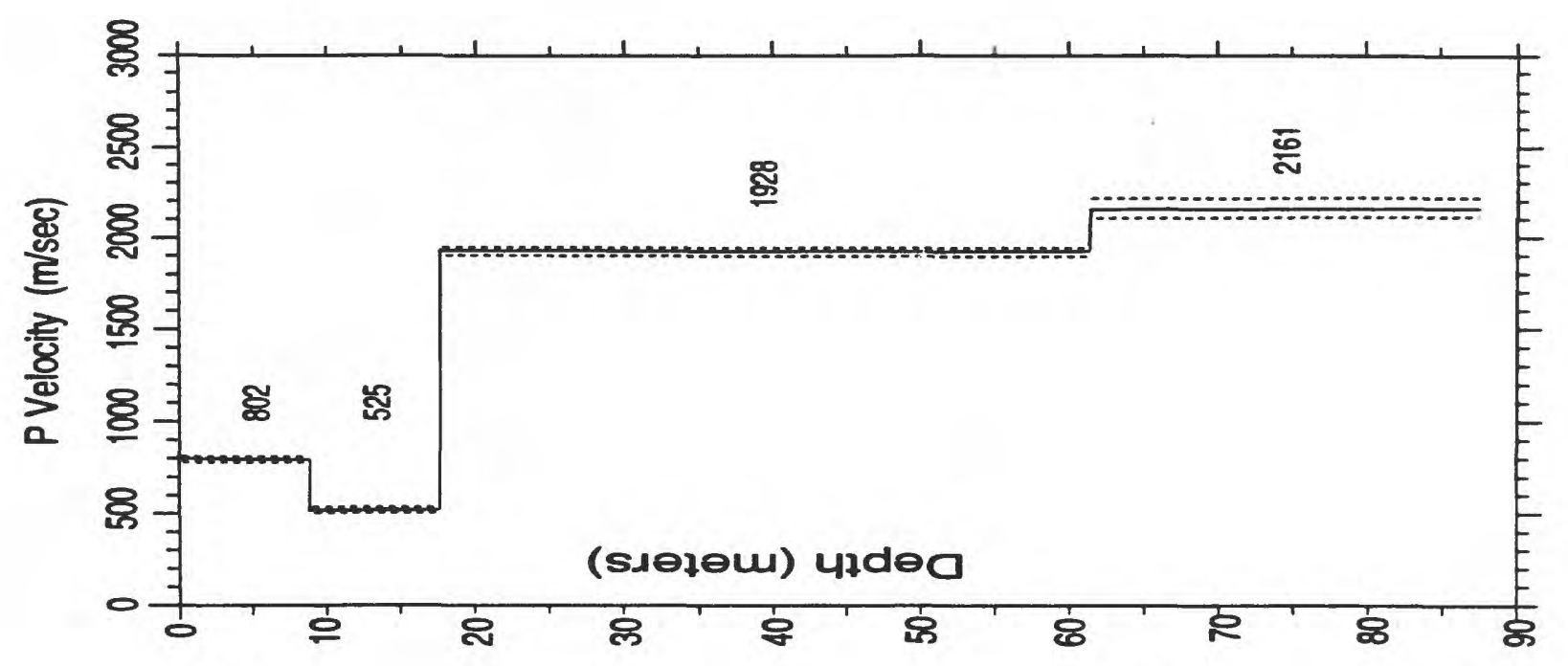

蒐.

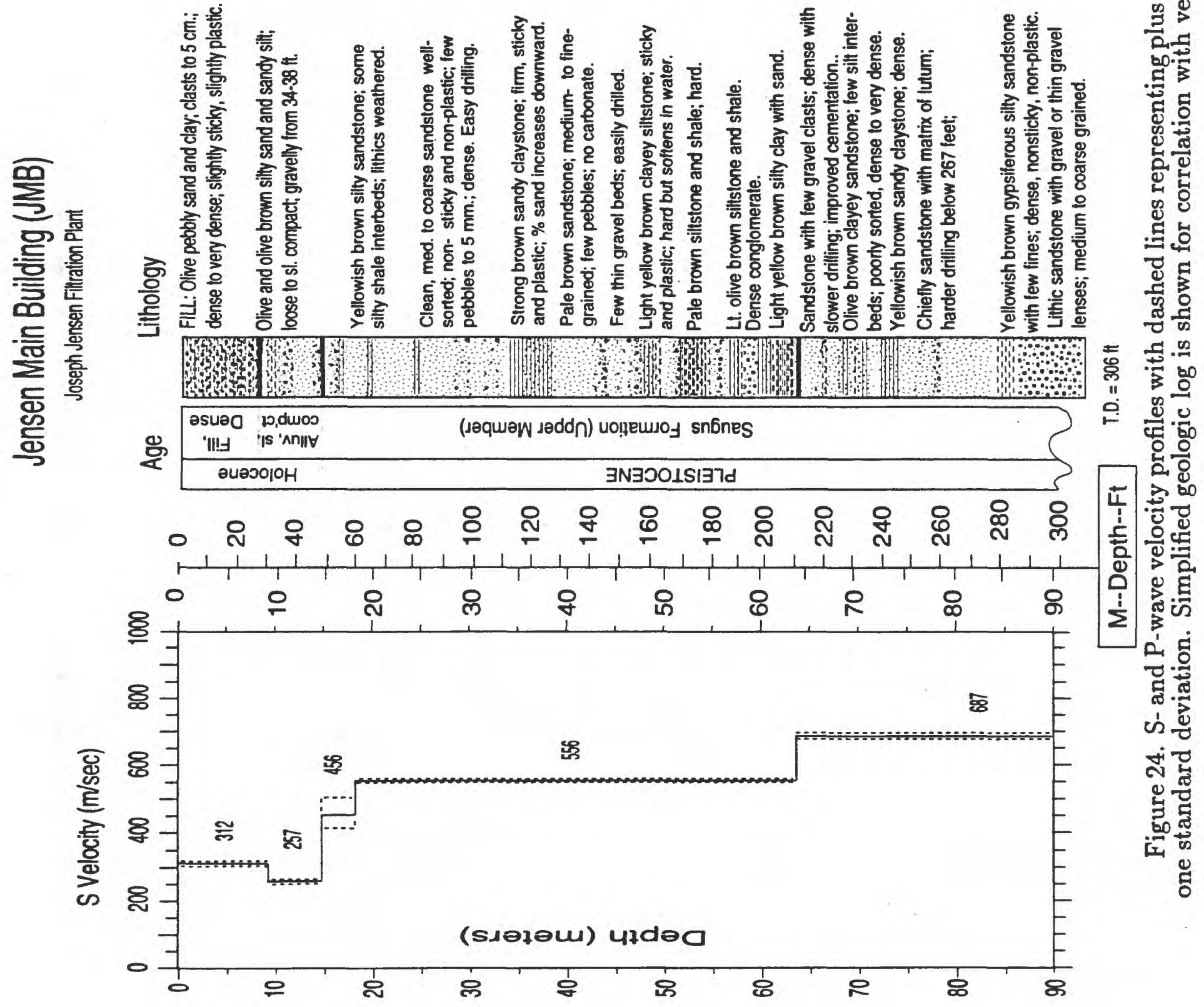




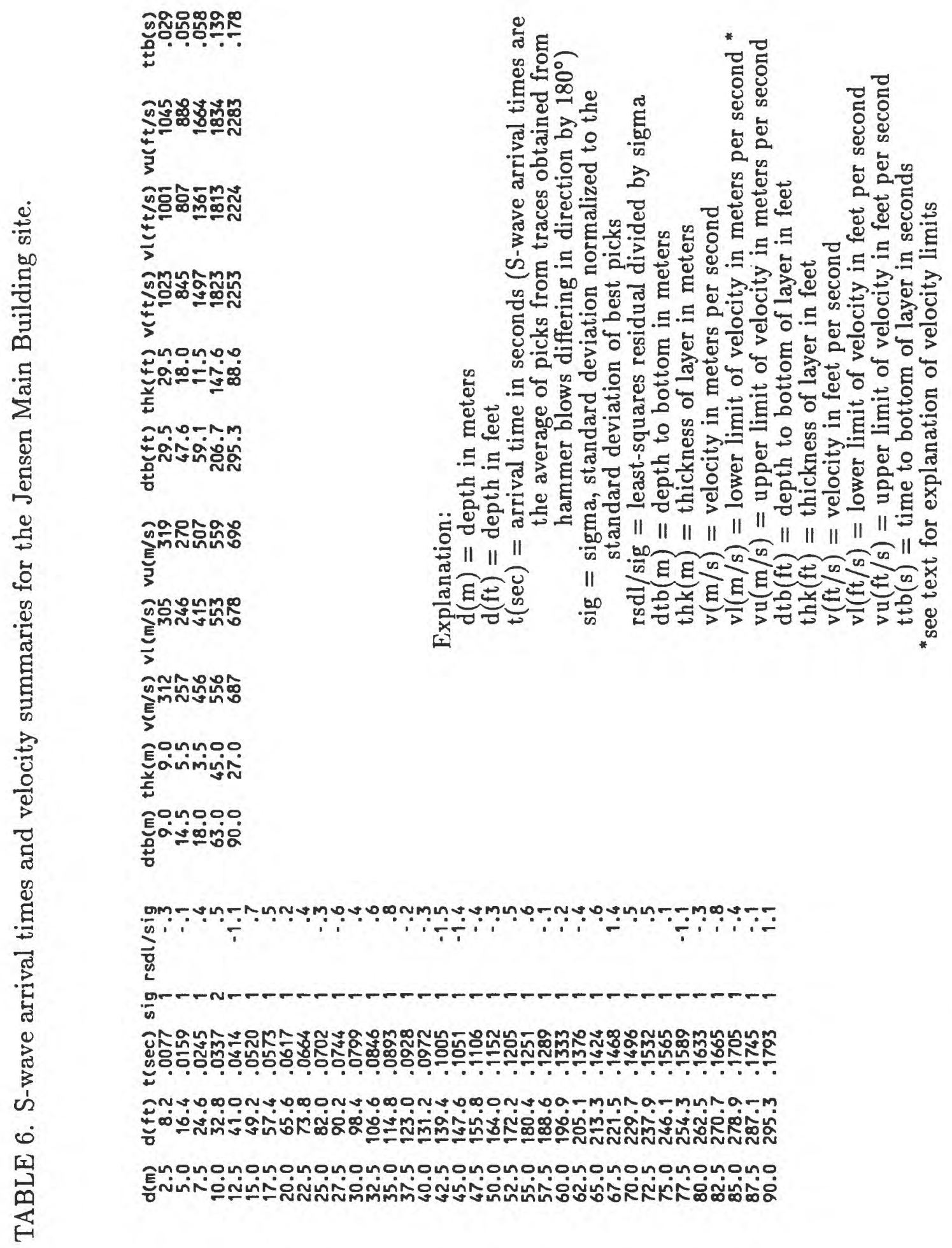




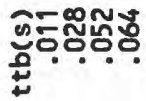

㠃

$\frac{0}{4}$

夏

클

돌

要

둥

$\stackrel{2}{1}$

동

过

过

龸

$\rightarrow$

$\frac{.7}{0}$

욤

\&

몬

तृ

蛋

$\sum_{0}^{0}$

A.

i

[T)

क्षे

4

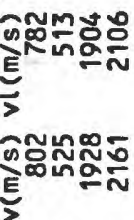

ติํํำำำ

క

E़oioiñ

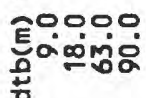

ํำ

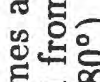

年

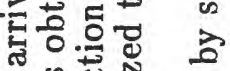

ए

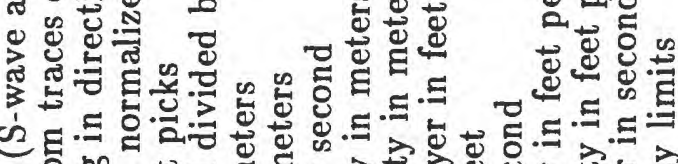

约

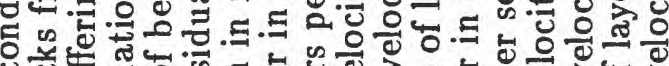

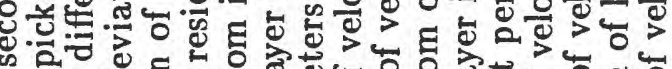

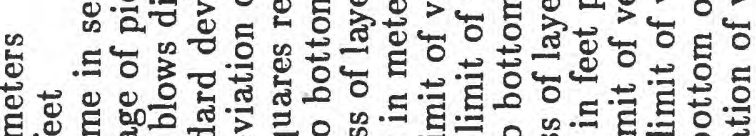

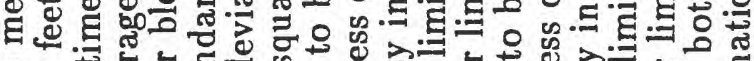

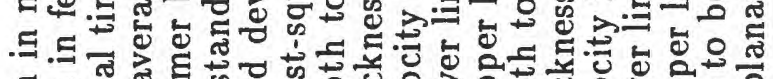

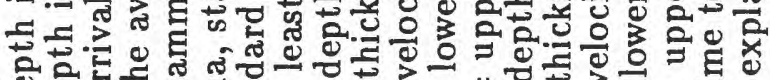

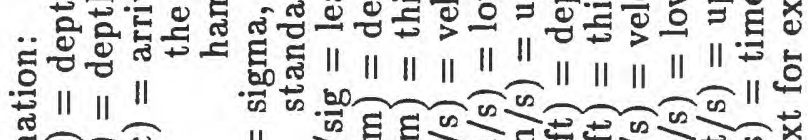

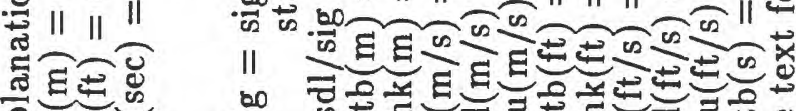

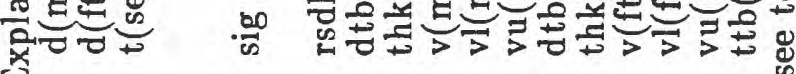

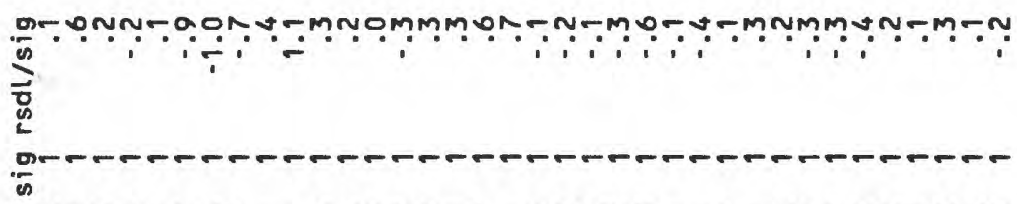

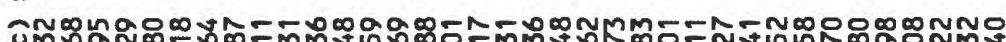

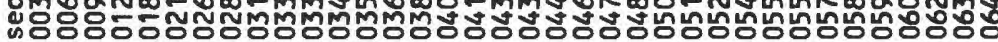

ప †

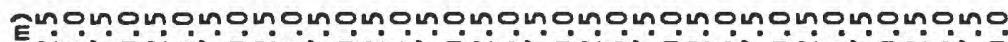

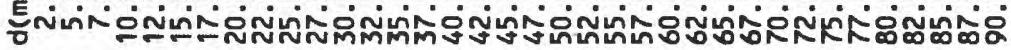




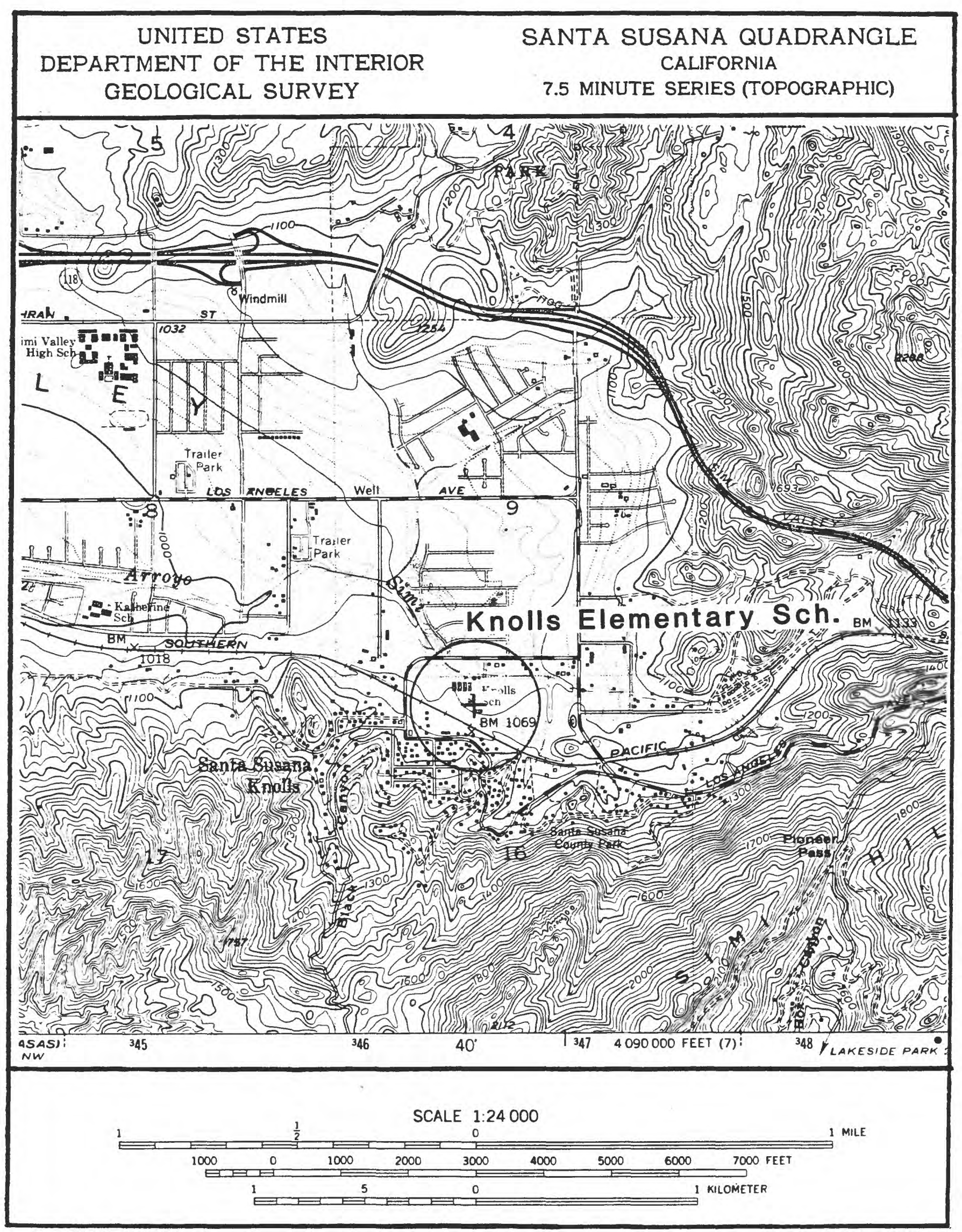

Figure 25. Site location map for the borehole at Knolls Elementary School. The accelerograph is located approximately 25 meters from the borehole. 


\section{S-WAVE}

\section{Time (sec)}

$\begin{array}{lll}0 & 0.1 & 0.2\end{array}$

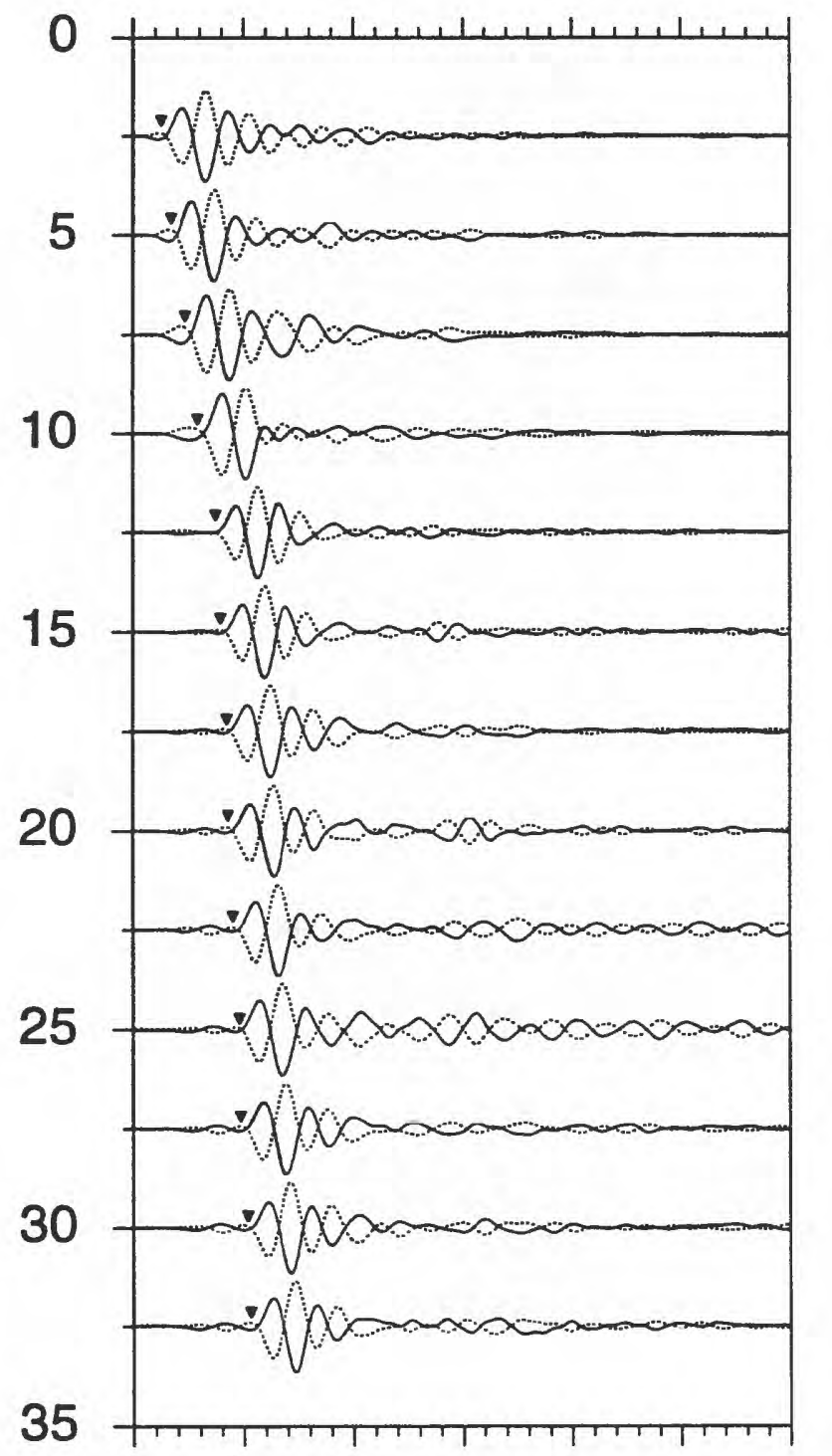

Time (sec)

0.3

0

0.1

0.2

0.3

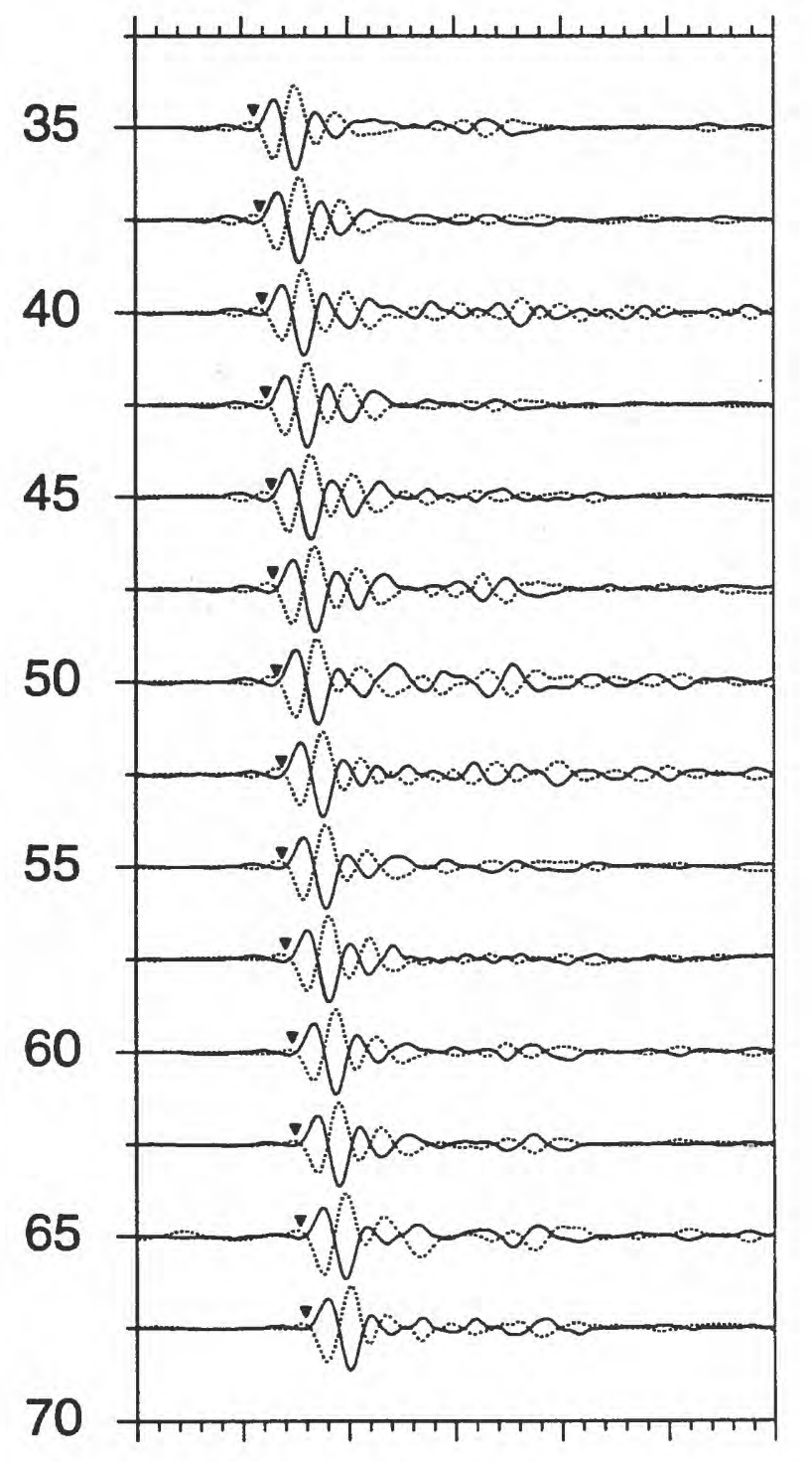

\section{Knolls Elementary School}

Figure 26. Horizontal component record section (from impacts in opposite directions) superimposed for identification of S-wave onset. Approximate S-wave time picks are indicated by the inverted triangles. 


\section{P-WAVE}

Time (sec)

$\begin{array}{lllll}0 & 0.05 & 0.1 & 0.15 & 0.2\end{array}$

$\begin{array}{lllll}0 & 0.05 & 0.1 & 0.15 & 0.2\end{array}$
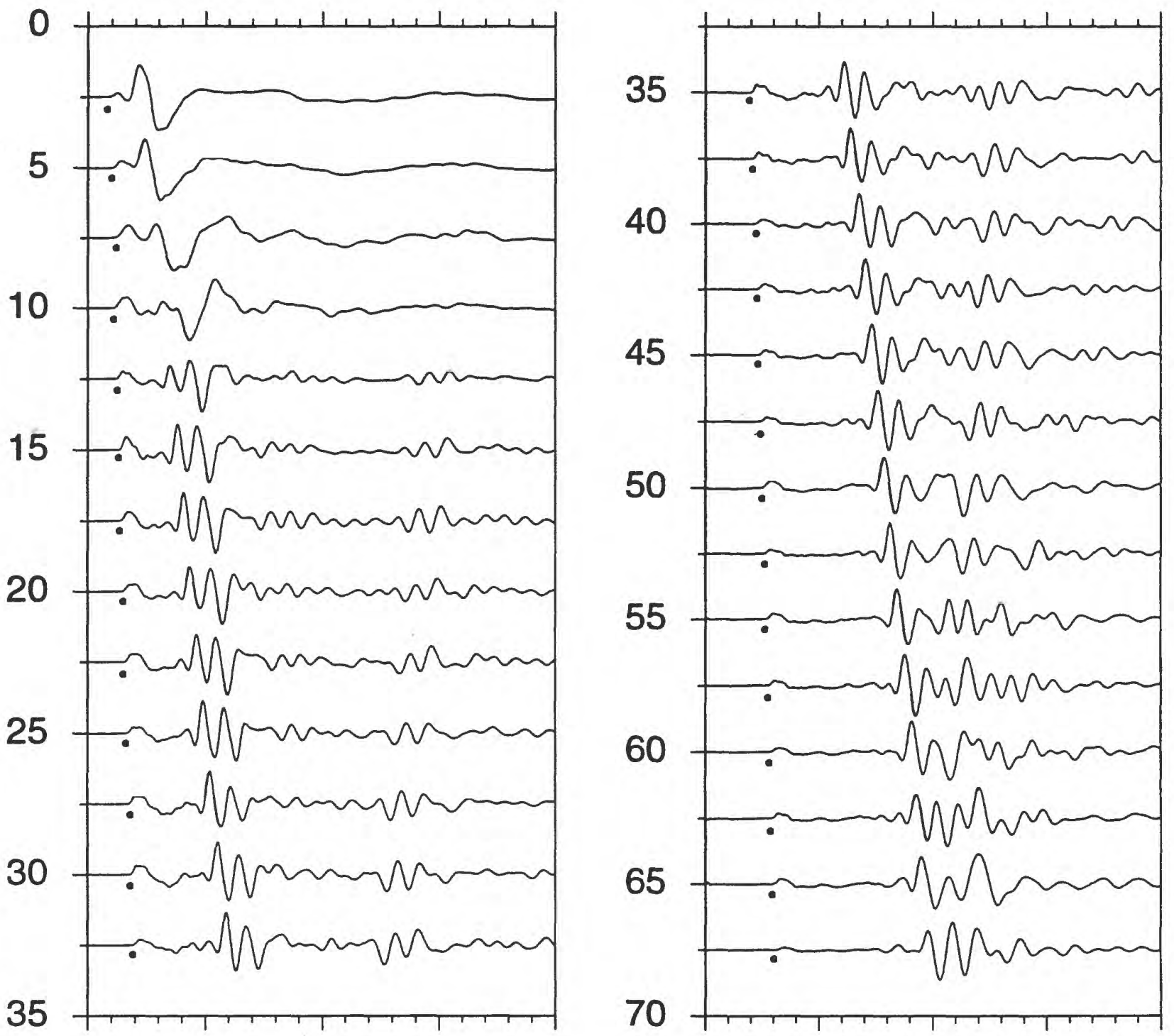

Knolls Elementary School

Figure 27. Vertical component record section. P-wave arrivals are indicated by the solid circles. 


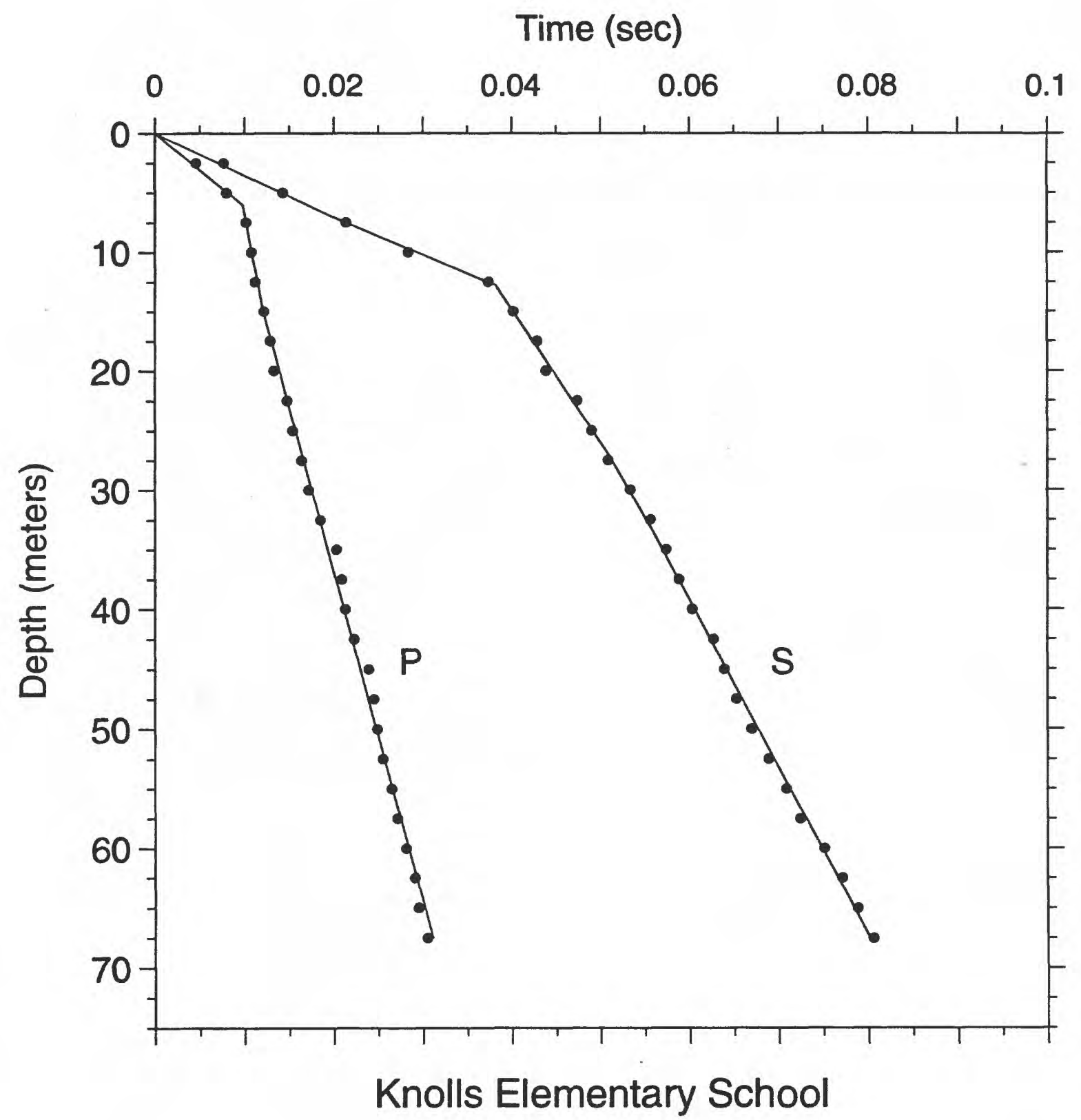

Figure 28. Time-depth graph of $\mathrm{P}$-wave and S-wave picks. Line segments show the hinged-least-squares fit to the data points. 


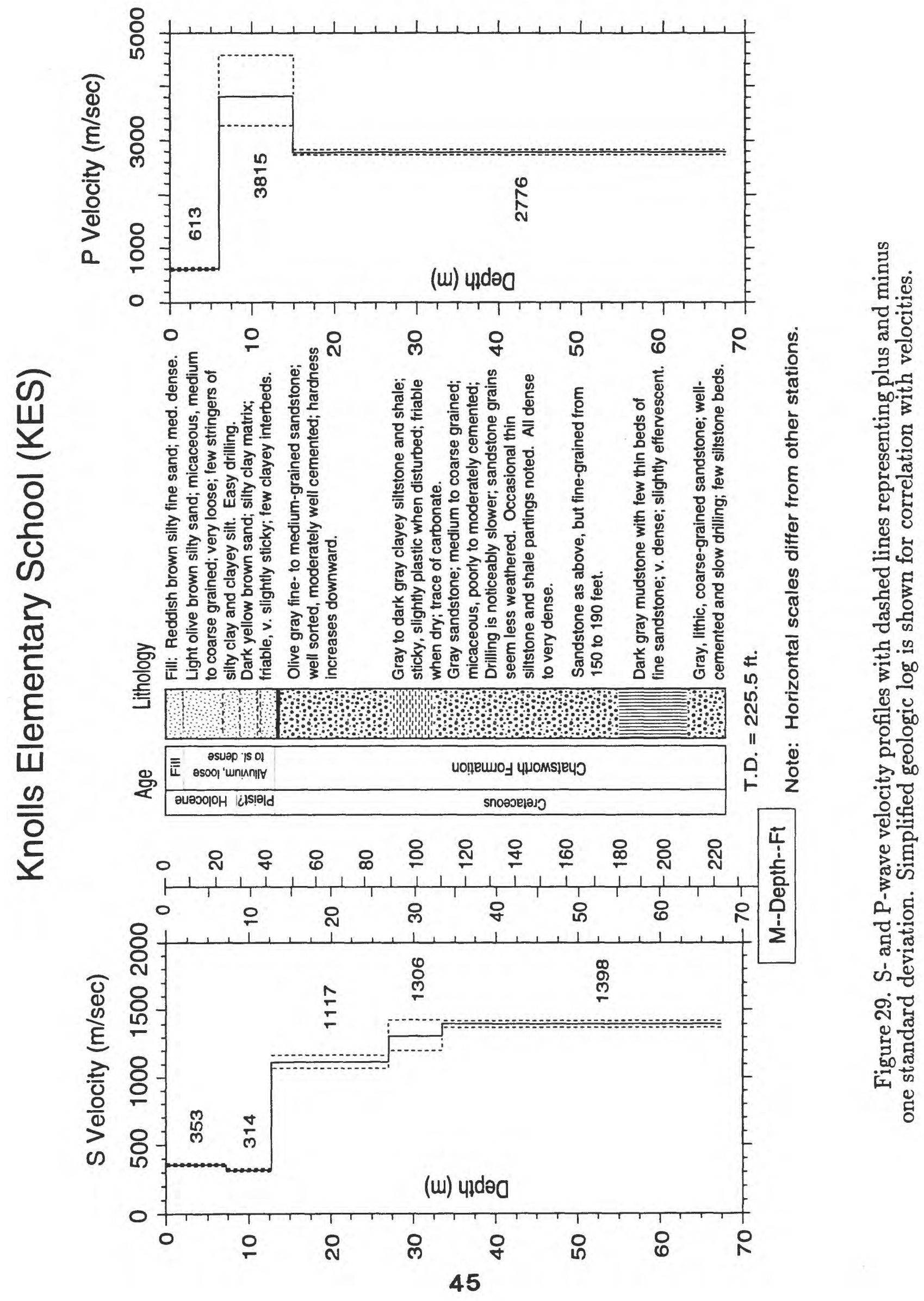




융

ลี

埅

द्व

田

$\stackrel{5}{\circ}$

0

웅

t?

(5)

:

ज़

$\frac{1}{8}$

물

$\stackrel{8}{3}$

क्ष

.

荧

$\infty$

뙤

空
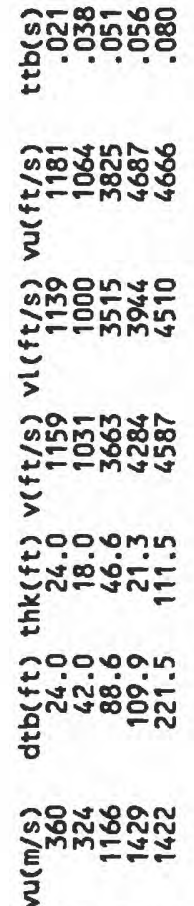

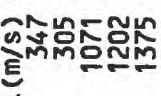

$\frac{1}{>}$

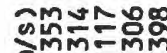

छ

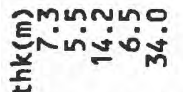

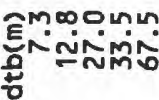

突

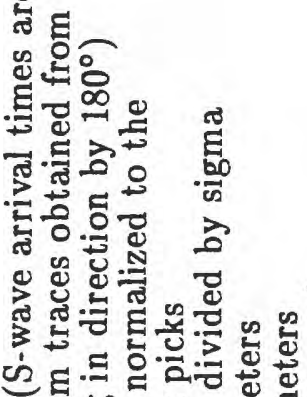

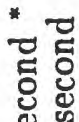

凹ू

它氙

in

悹芯

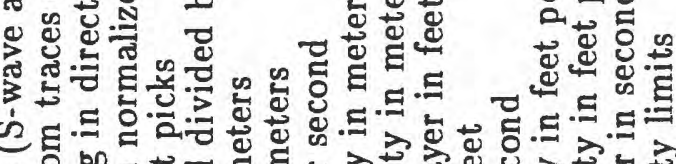
bo

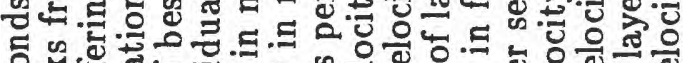

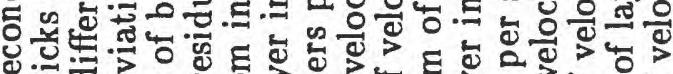

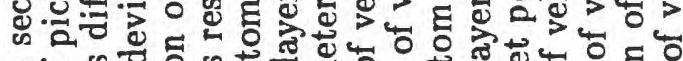
D. 5 出

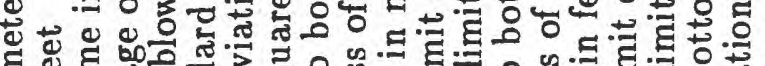

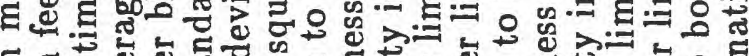

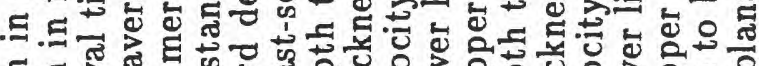

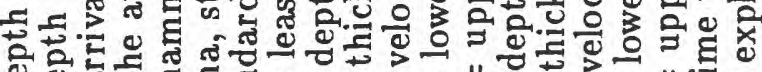

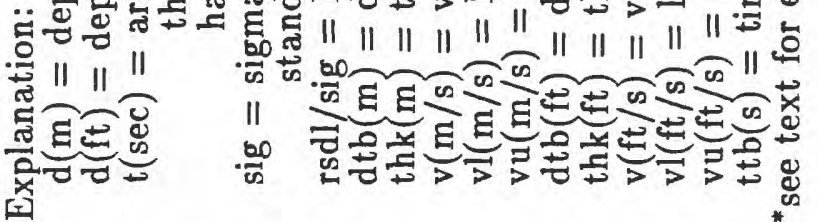

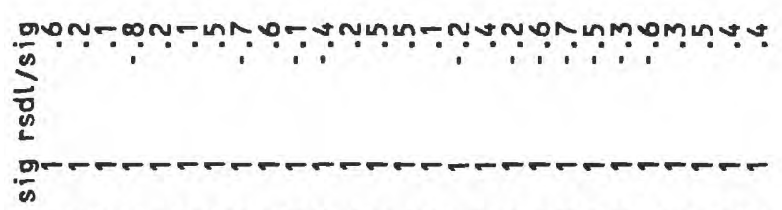

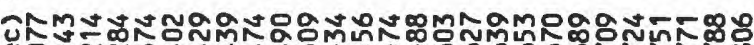

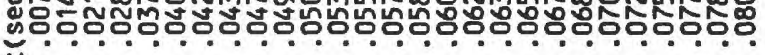
2n

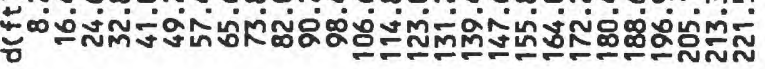

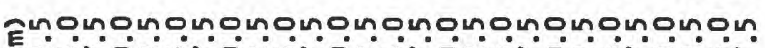

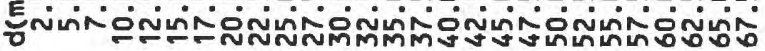




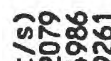

ํํㄹ

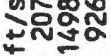

윤용

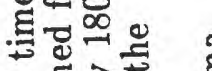

고을 긍

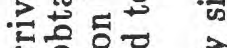

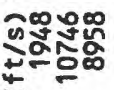

둥용

$\bar{\gamma}$

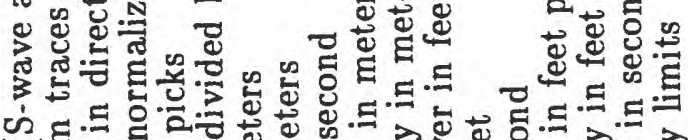

กิำลำ

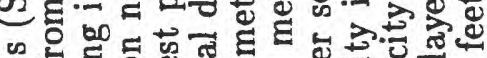

$. \Xi . \Xi$

\

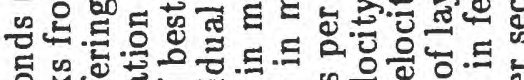

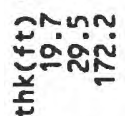

Fonan

ติบี้ำ

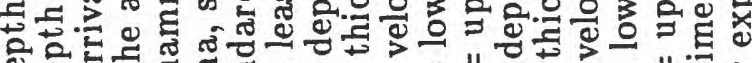

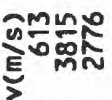

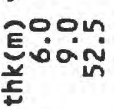

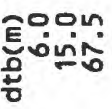

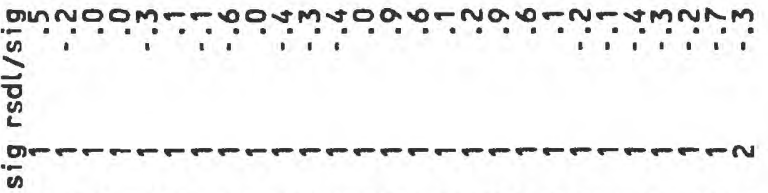

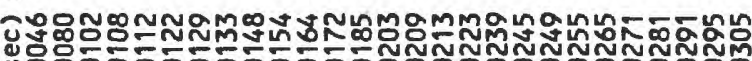

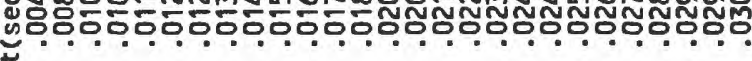

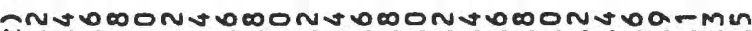
\%

$\dot{\infty}$

Cnonounononoinonononounonononom ฮั 


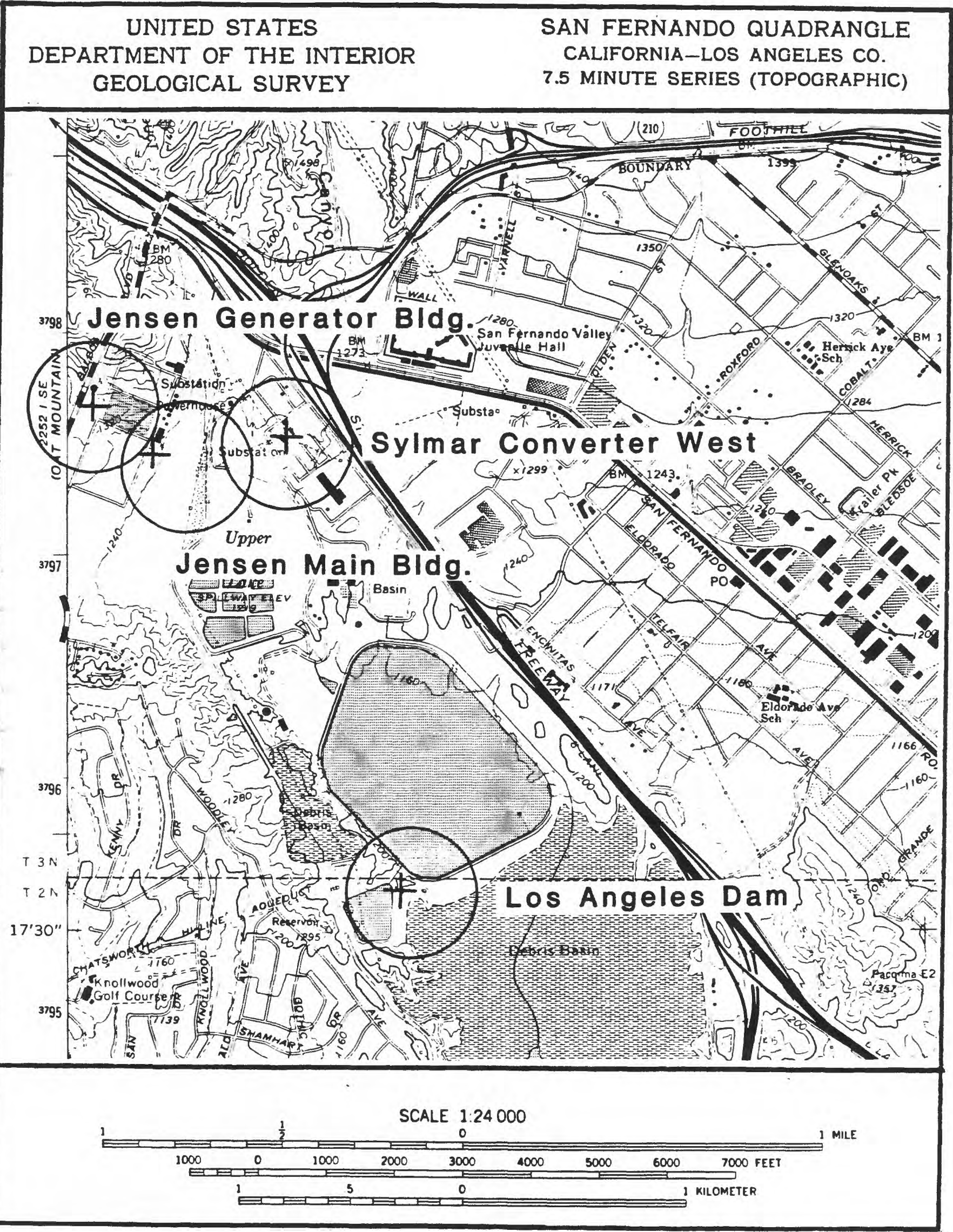

Figure 30. Site location map for the borehole at Los Angeles Dam. The accelerograph is located approximately 35 meters from the borehole. 


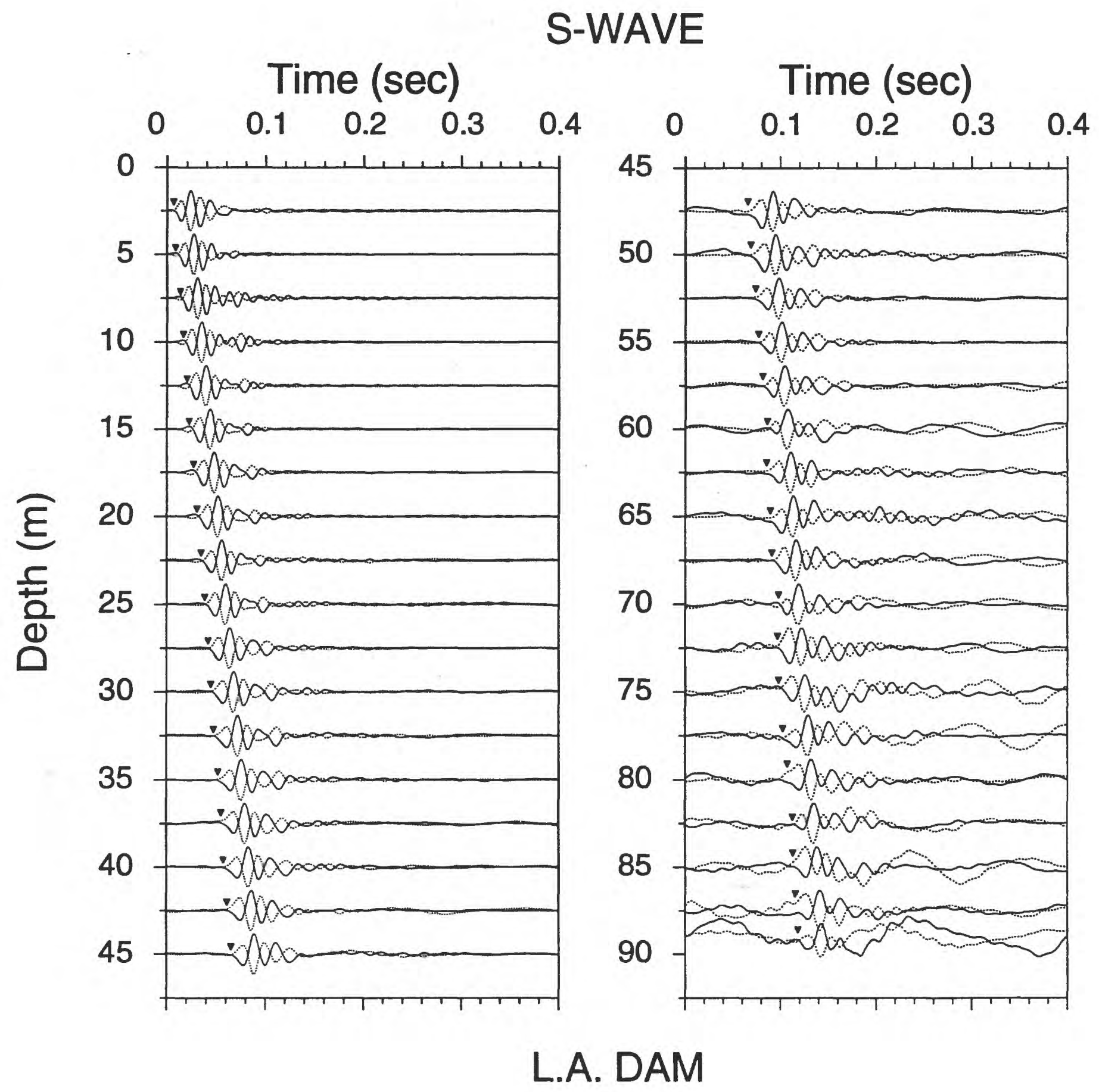

Figure 31. Horizontal component record section (from impacts in opposite directions) superimposed for identification of S-wave onset. Approximate S-wave time picks are indicated by the inverted triangles. 


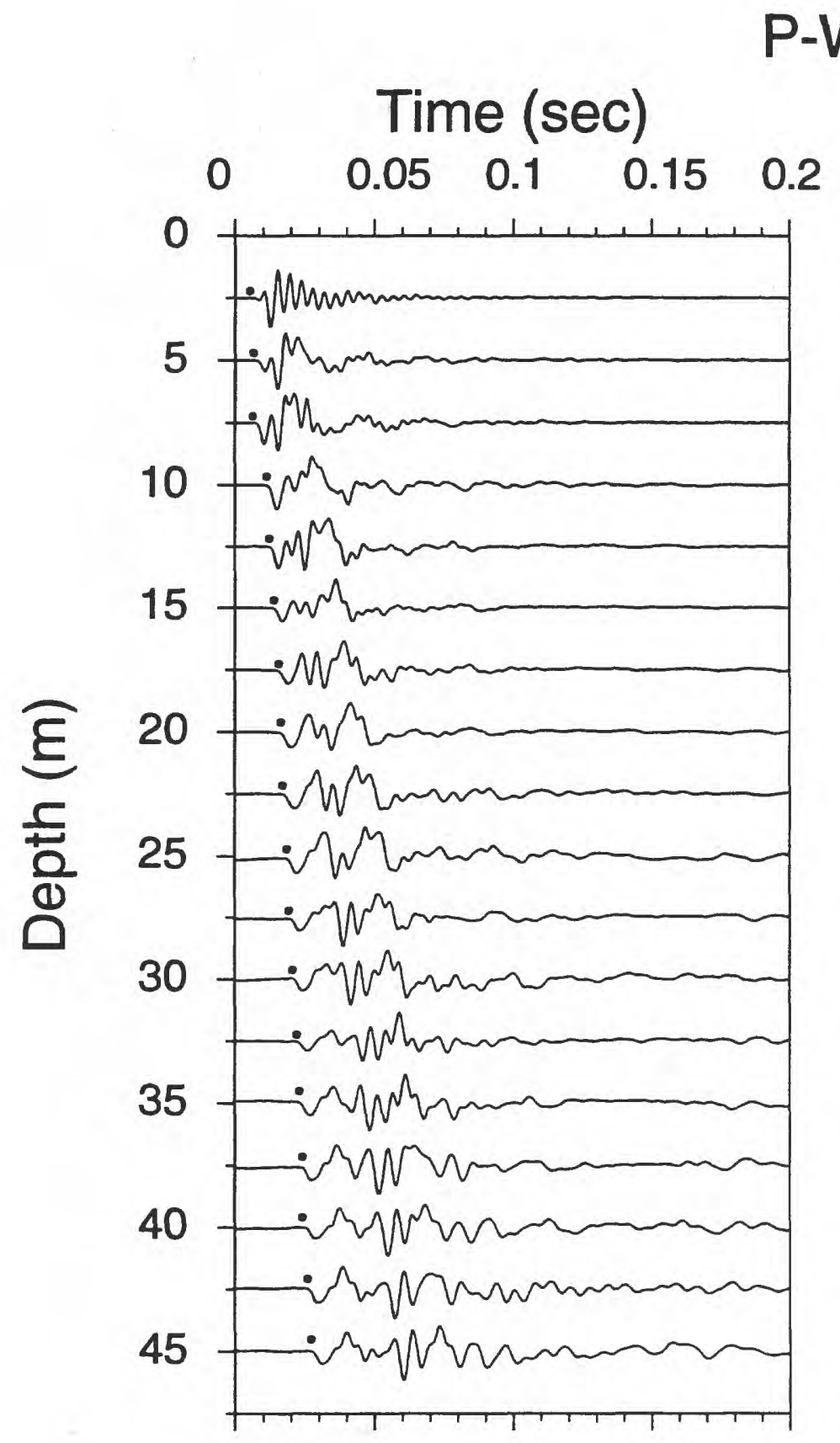

Time (sec)
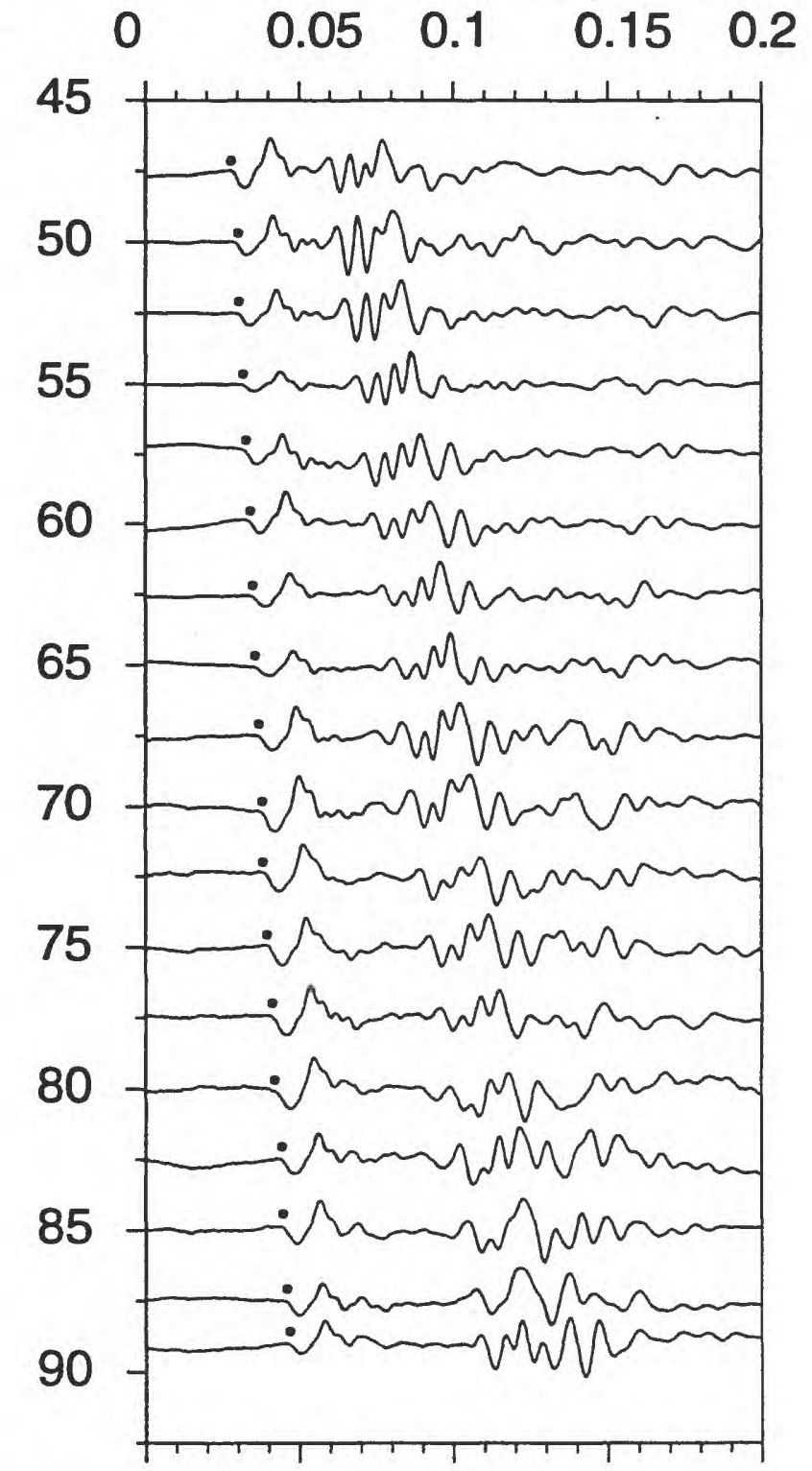

L.A. DAM

Figure 32. Vertical component record section. P-wave arrivals are indicated by the solid circles. 


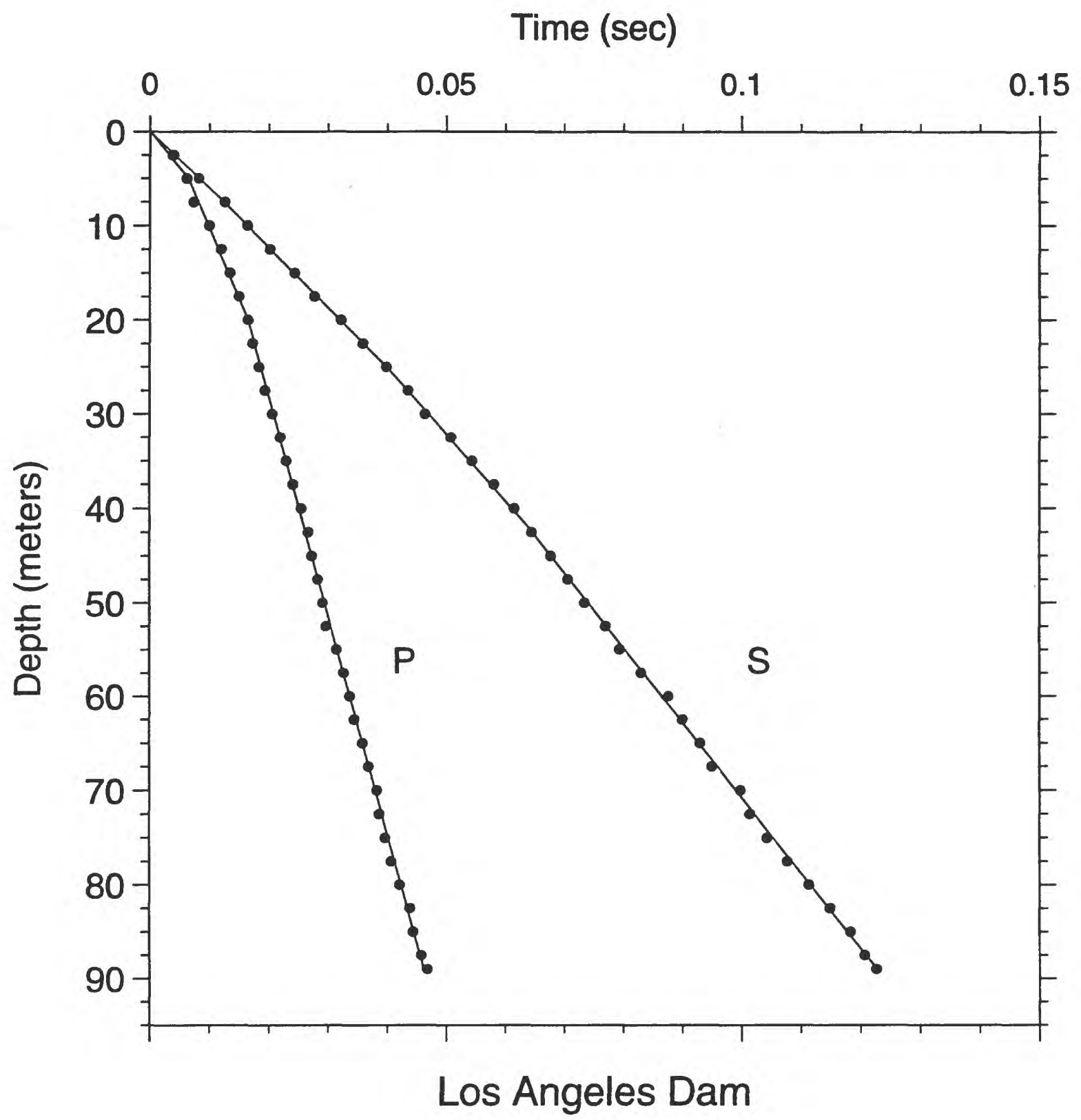

Figure 33. Time-depth graph of $\mathrm{P}$-wave and S-wave picks. Line segments show the hinged-least-squares fit to the data points. 


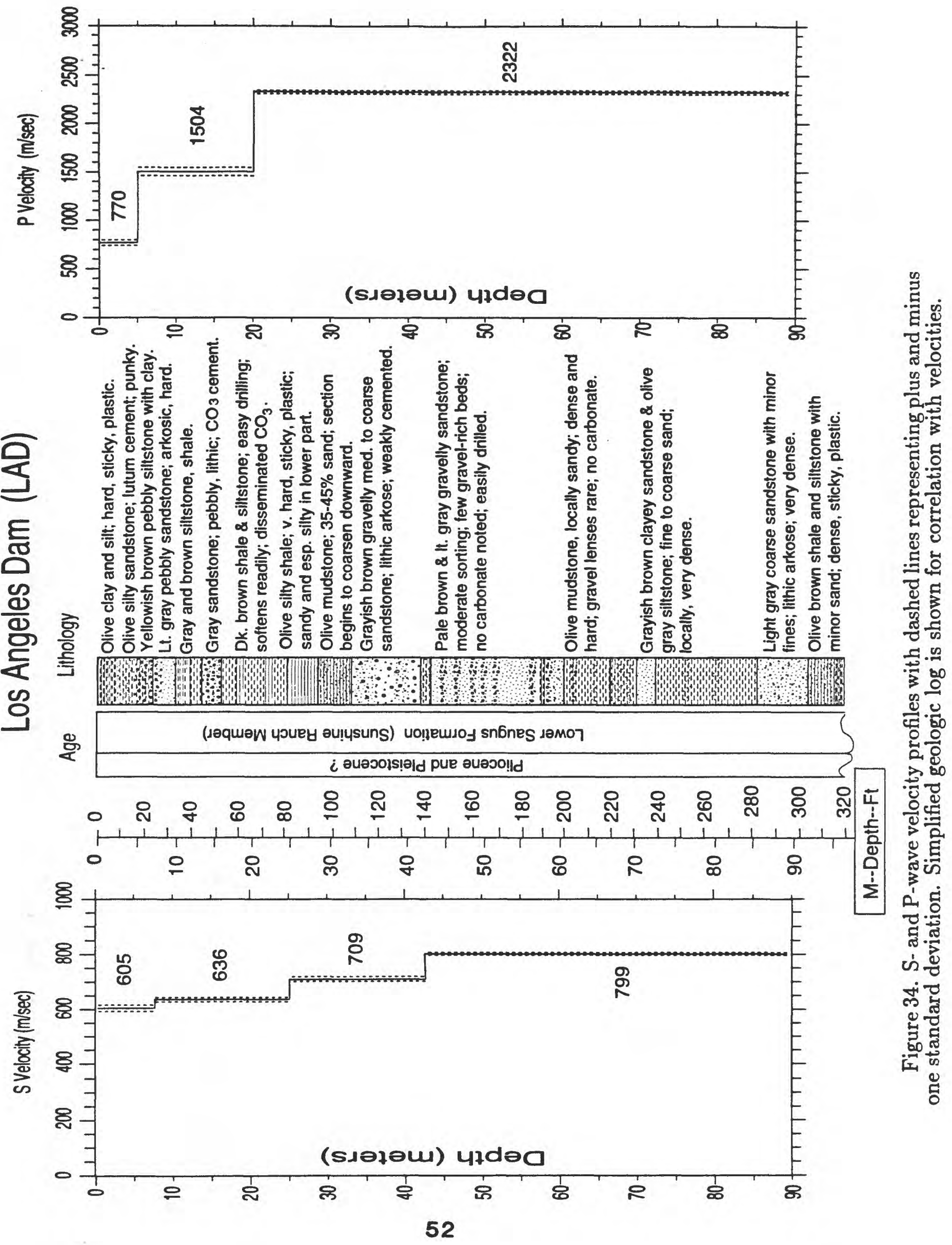


논 통

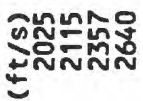

운용

텅

त.

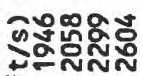

흉유 용

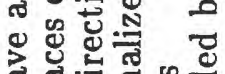

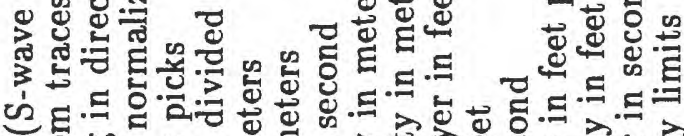

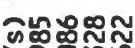

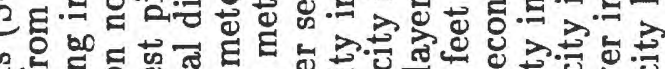

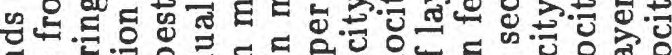
ต

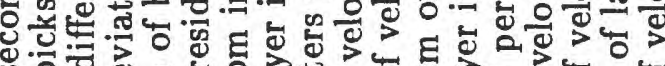
โับำกับ

क

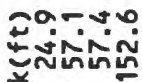

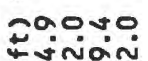

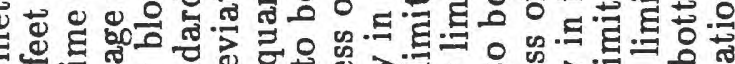

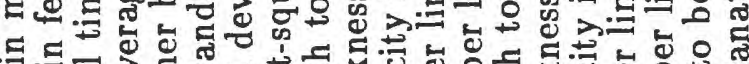
․ㅡ드릴

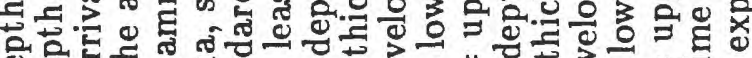

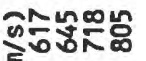

引

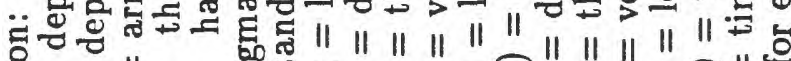
花

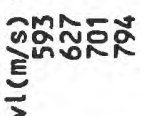
ติํํํํํำ<smiles>[CH][CH]</smiles>

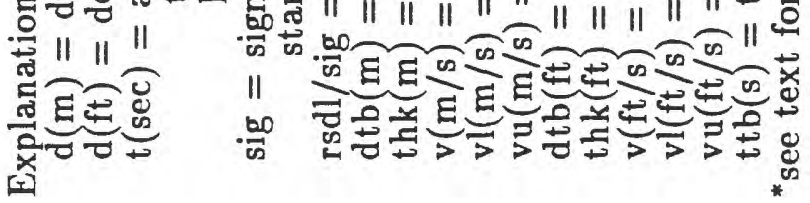

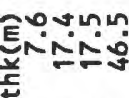

हैํำ

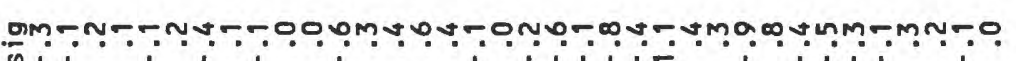

总 $\frac{70}{6}$

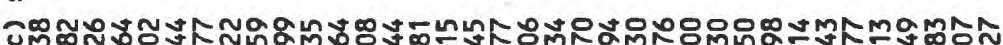

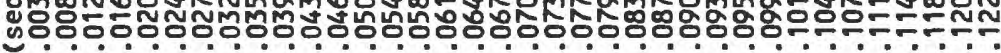

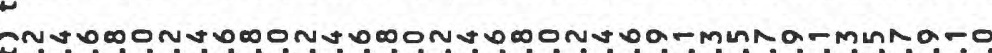

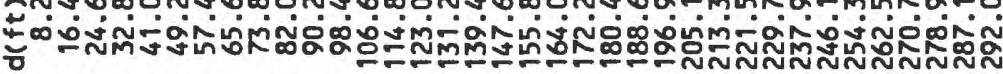

息

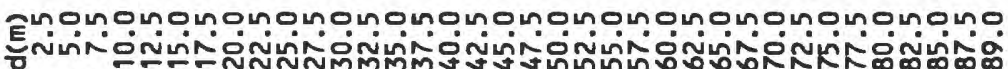




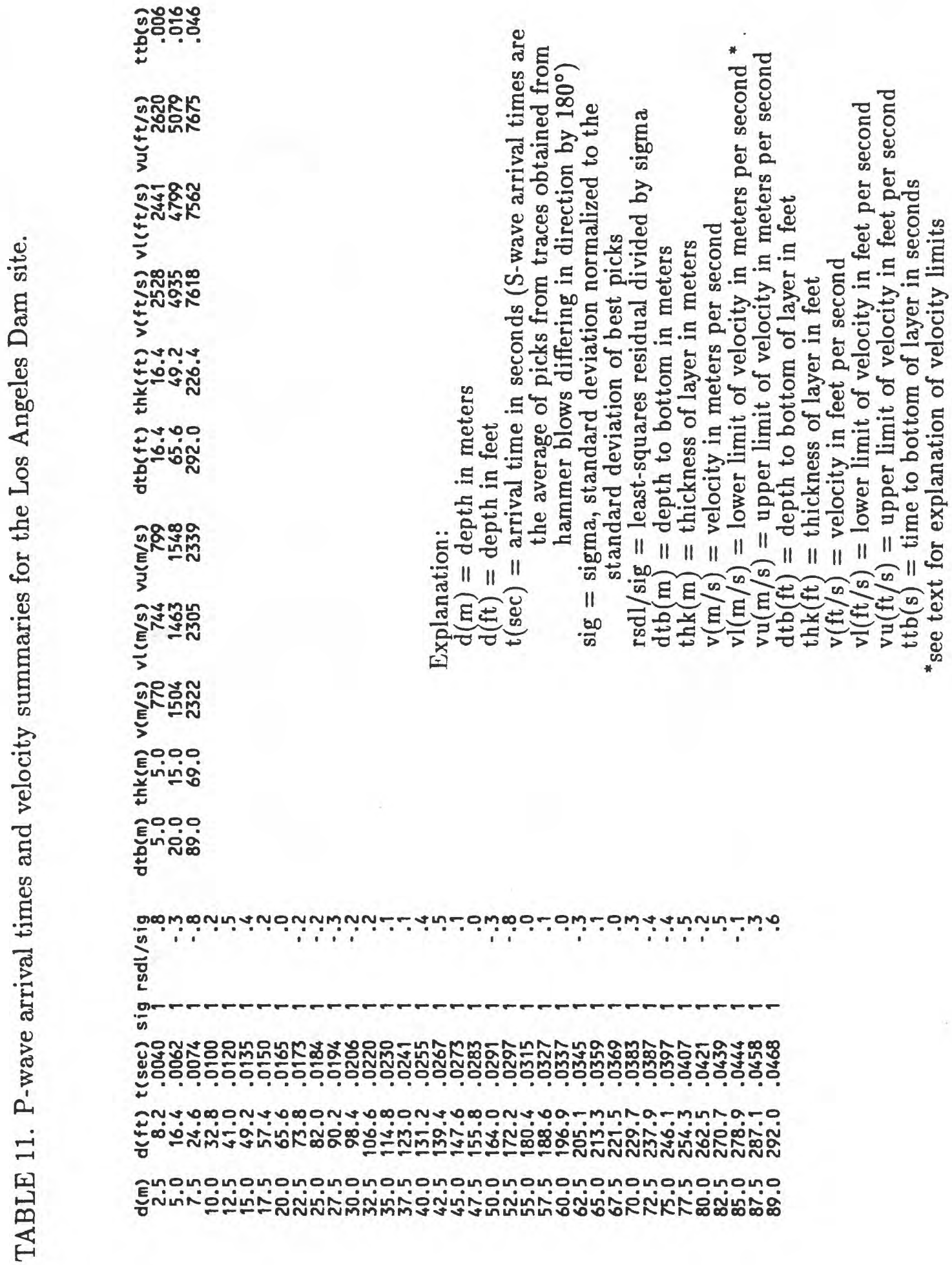




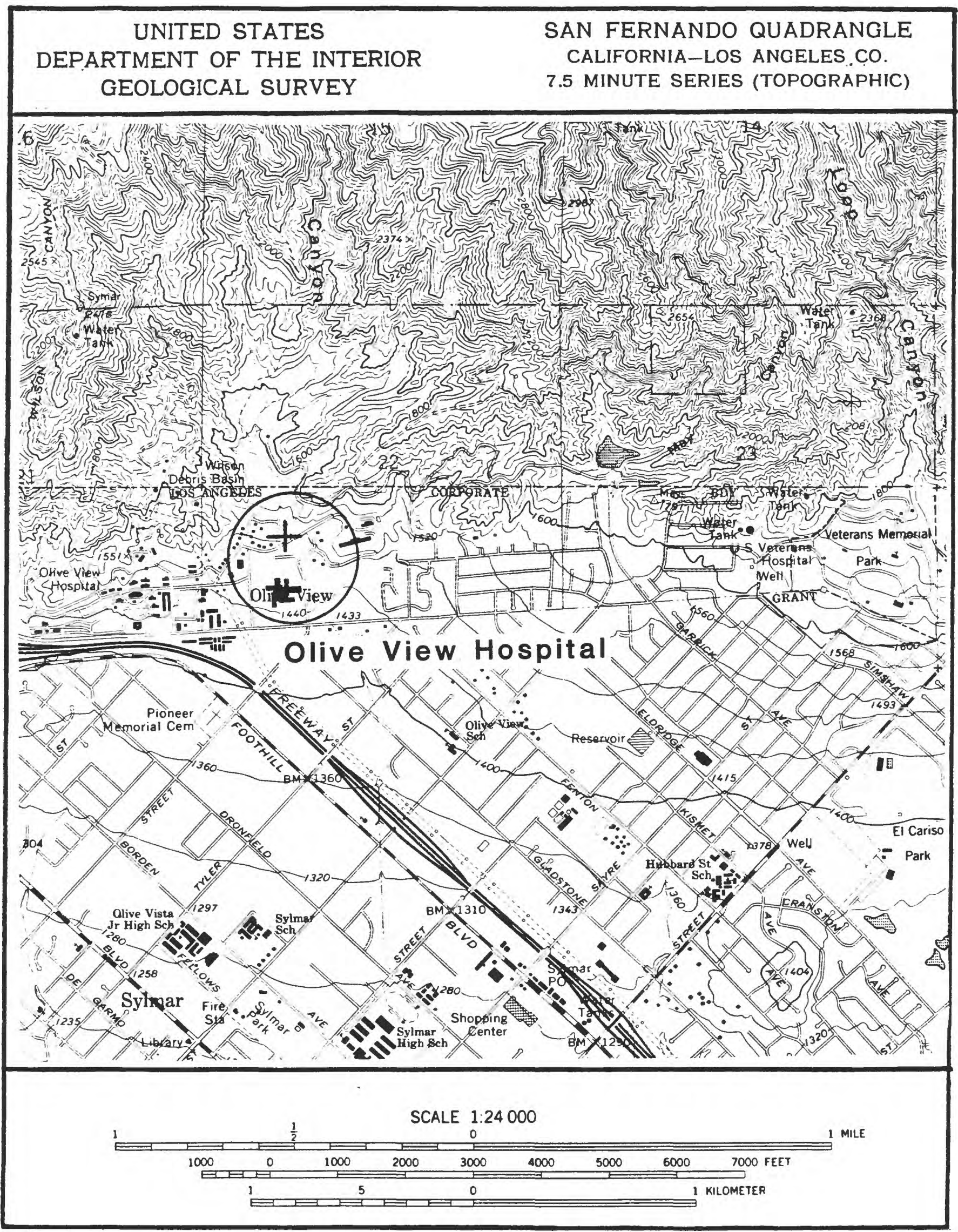

Figure 35. Site location map for the borehole at Olive View Hospital. The accelerograph is located approximately 30 meters from the borehole. 


\section{S-WAVE}

Time (sec)

\section{Time (sec)}

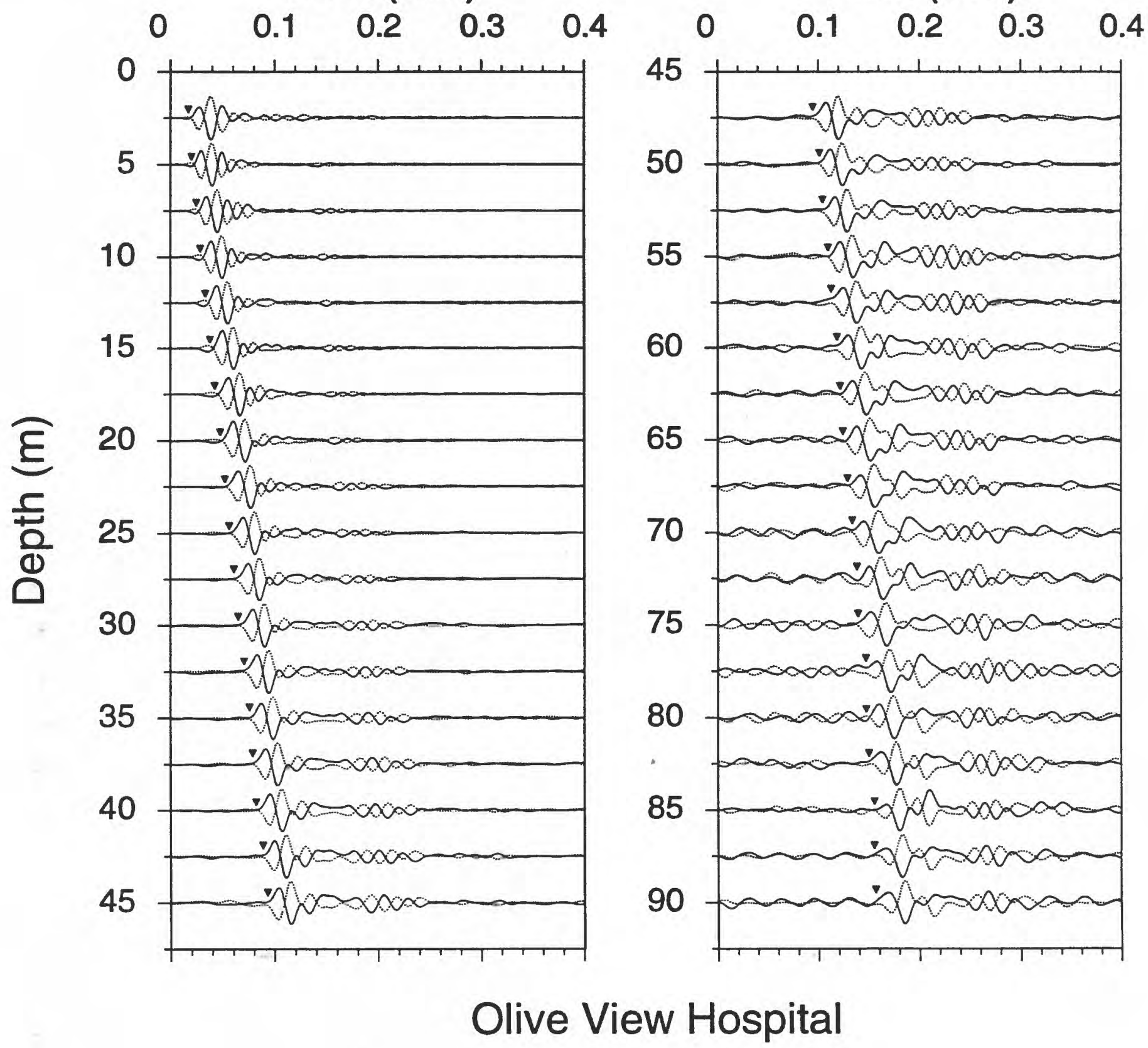

Figure 36. Horizontal component record section (from impacts in opposite directions) superimposed for identification of S-wave onset. Approximate S-wave time picks are indicated by the inverted triangles. 


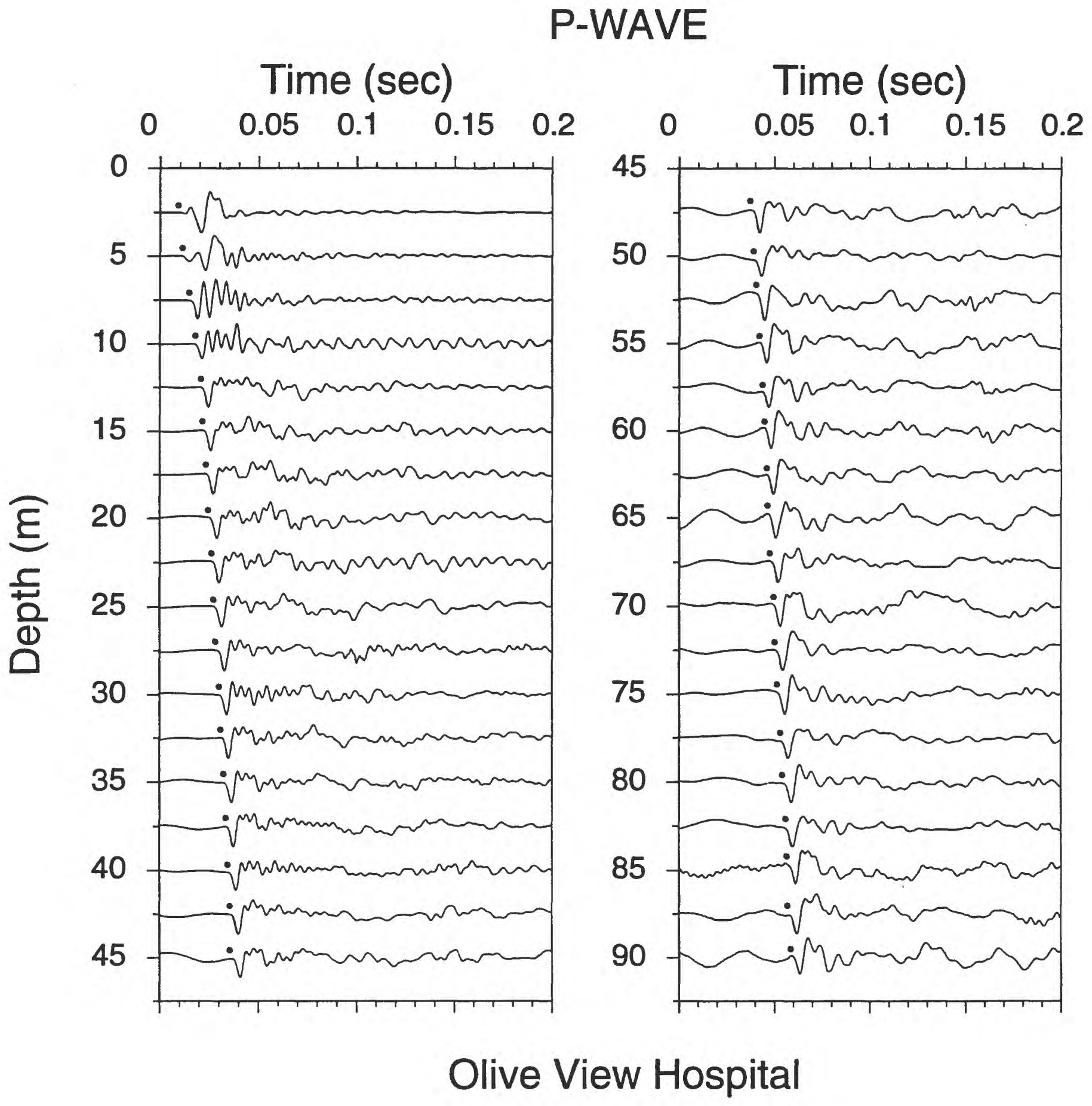

Figure 37. Vertical component record section. P-wave arrivals are indicated by the solid circles. 


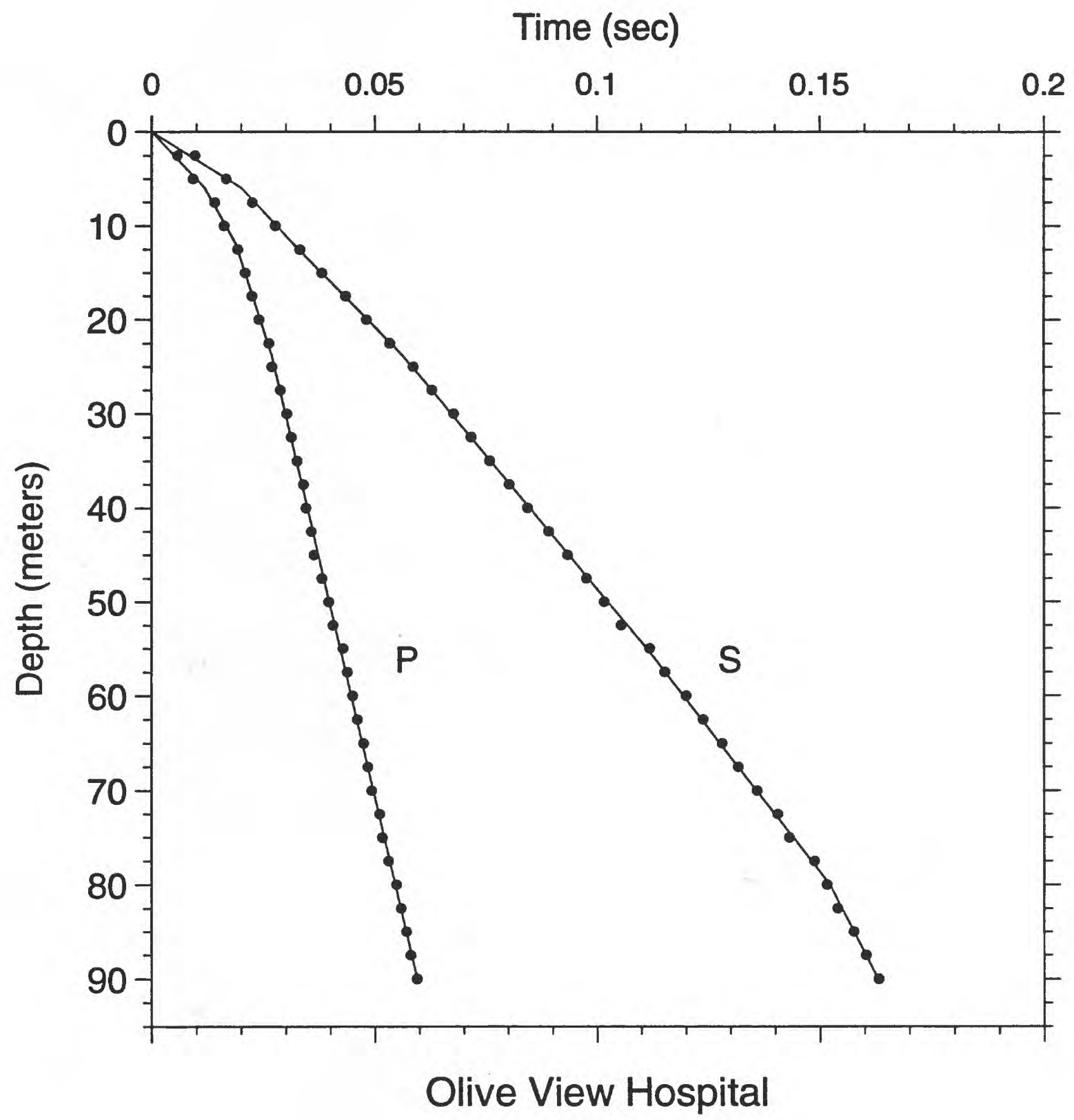

Figure 38. Time-depth graph of P-wave and S-wave picks. Line segments show the hinged-least-squares fit to the data points. 


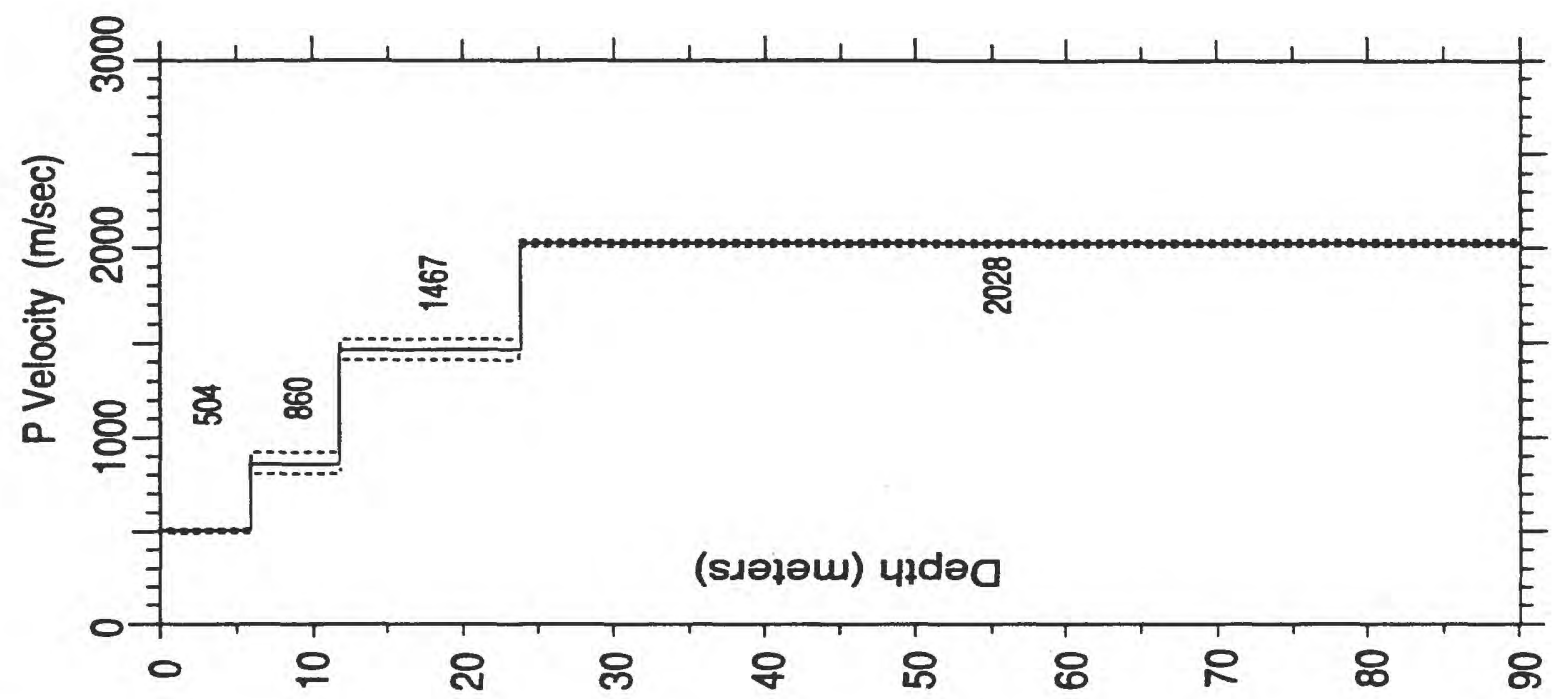

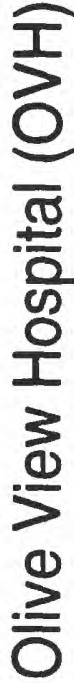
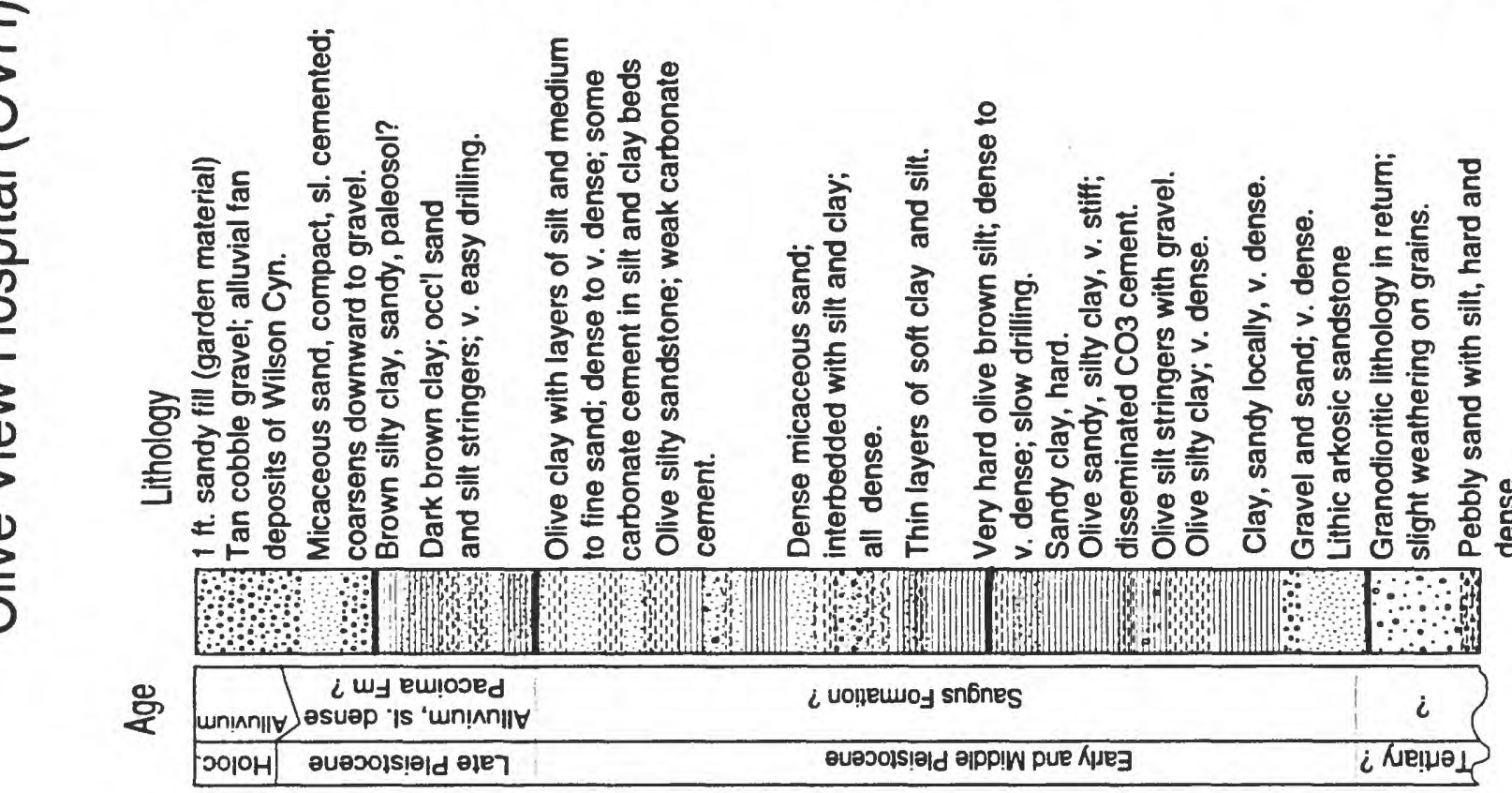

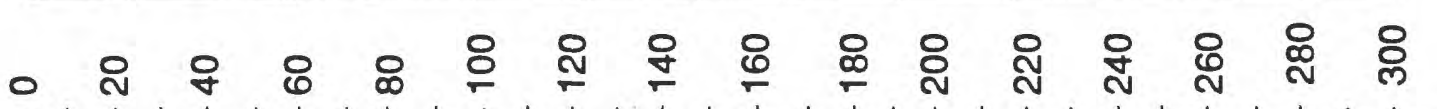

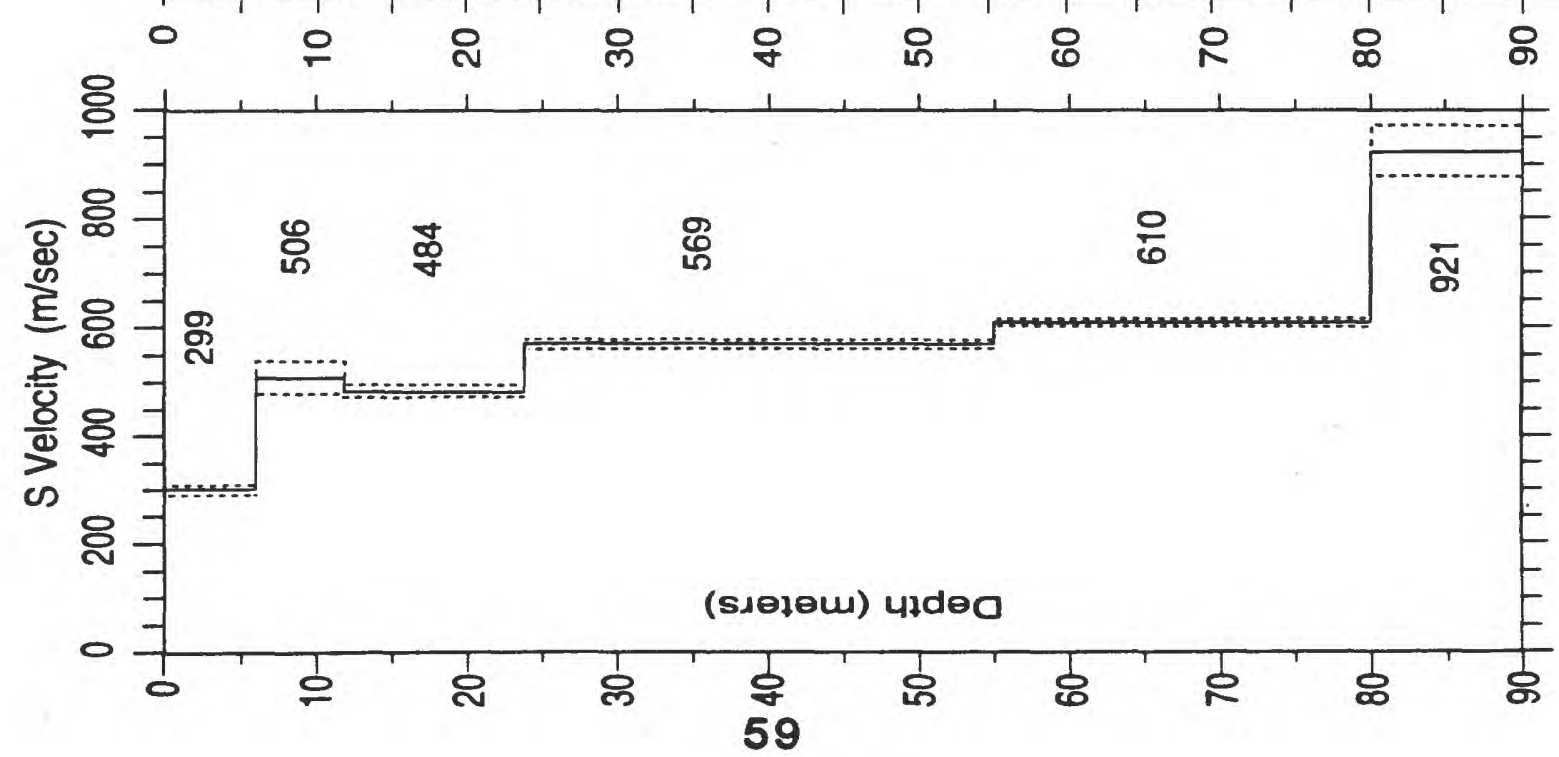


อิด

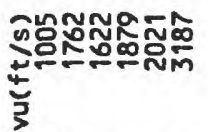

露

秀

$\stackrel{4}{\circ}$

ह

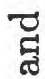

\&

.

तु

武

茨

ن́

$\stackrel{\dot{9}}{\mathfrak{H}}$

回

空

压

ตํํํํํํํำ

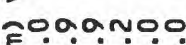

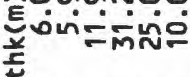

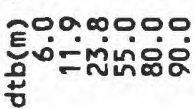

문

in
닐

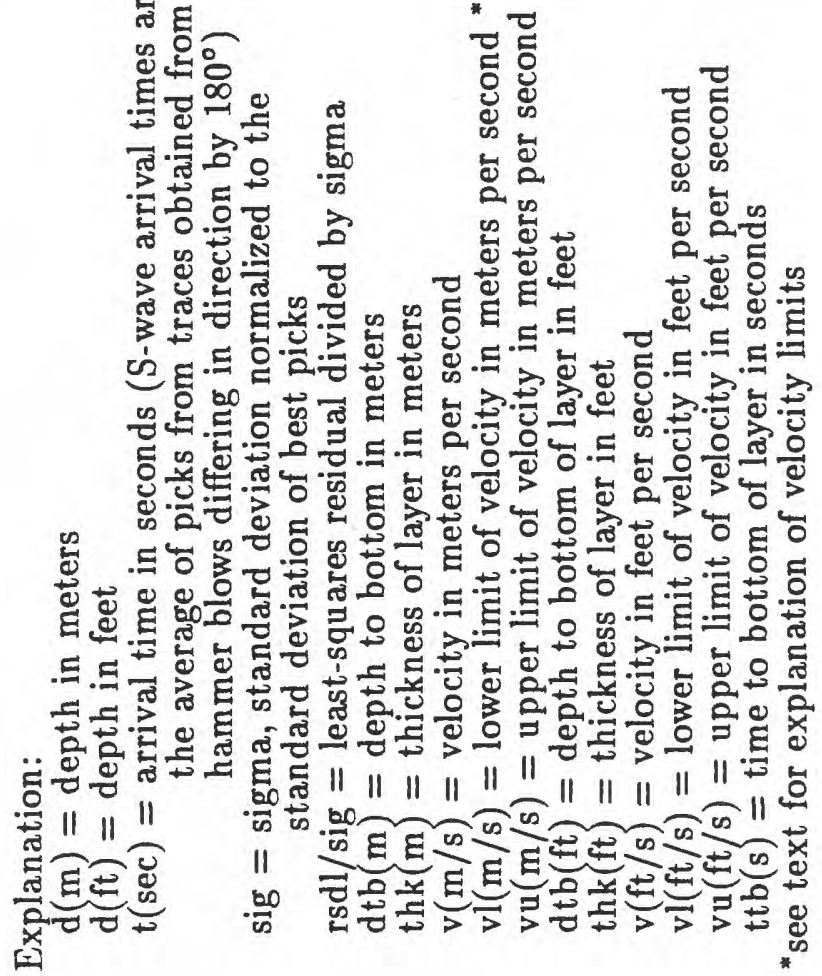

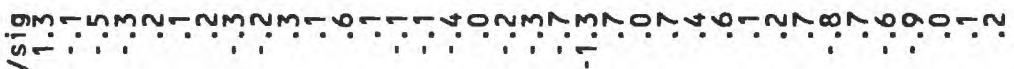

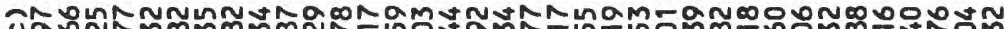

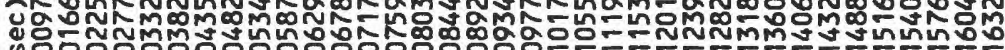

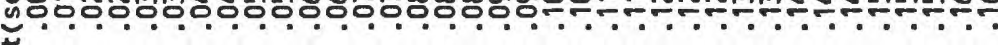

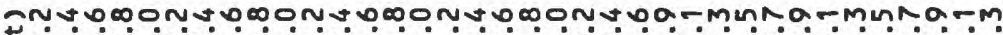

ซ

Enonononounononononononononononononono

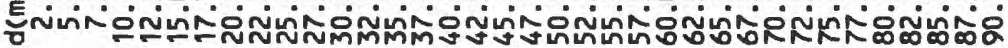


苟

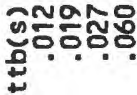

幽

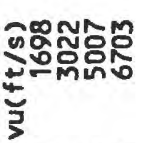

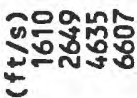

เั हี

운용

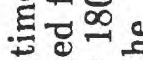

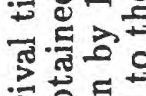

년휴 훙

동요월

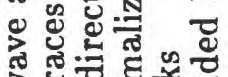

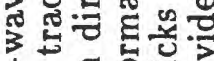

ติผ

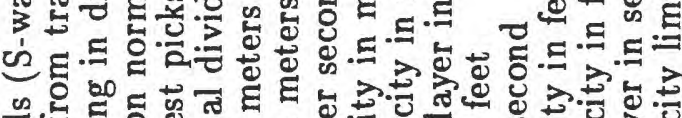

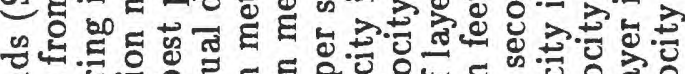

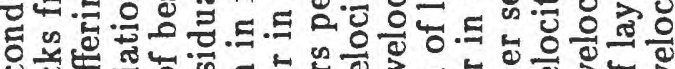

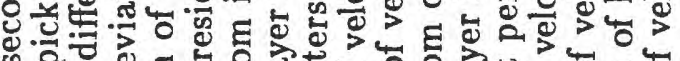

कृaigin

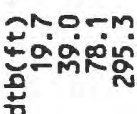

吾

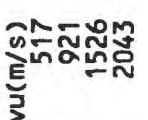

世

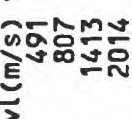

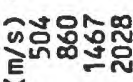

क $\quad$ W

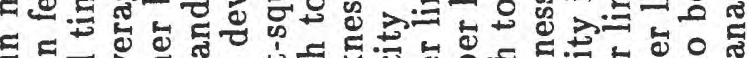

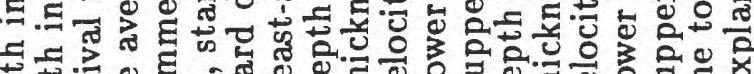

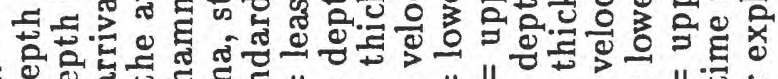

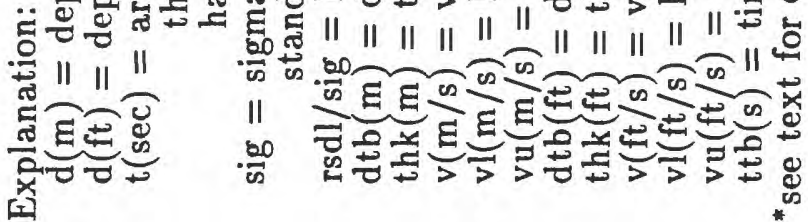

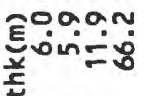

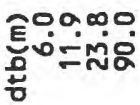

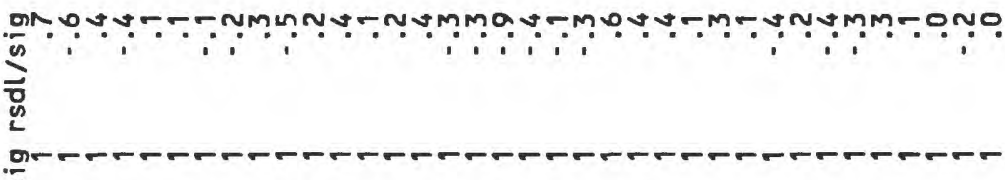

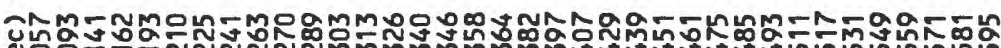

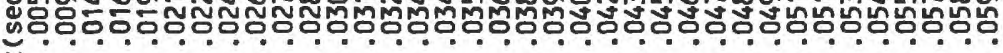

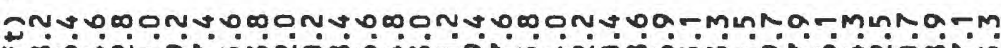

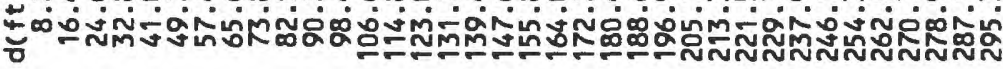

Enounoungunounounoungunounounoungunoungunounounguno

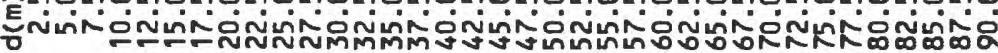




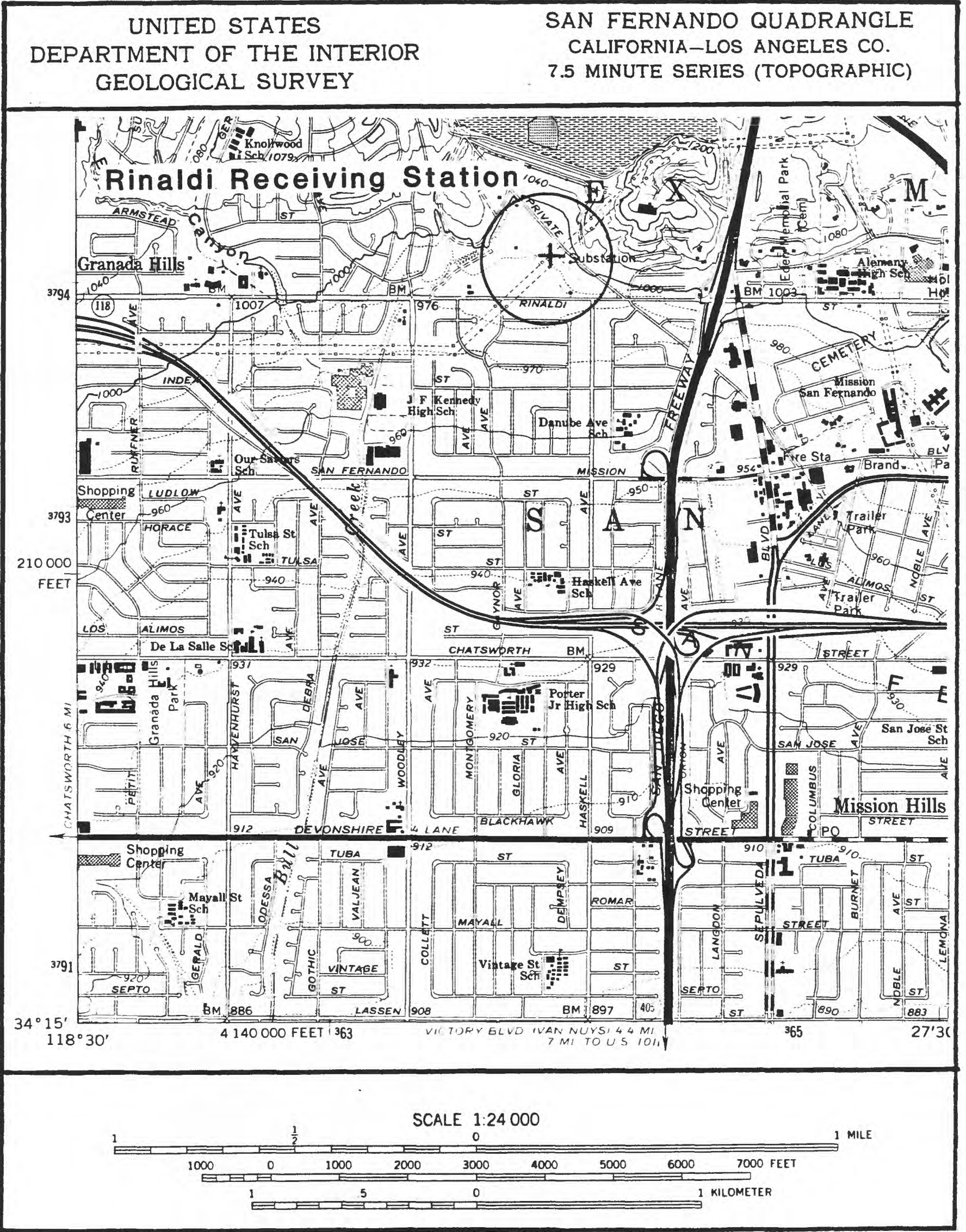

Figure 40. Site location map for the borehole at Rinaldi Receiving Station. The accelerograph is located approximately 10 meters from the borehole. 


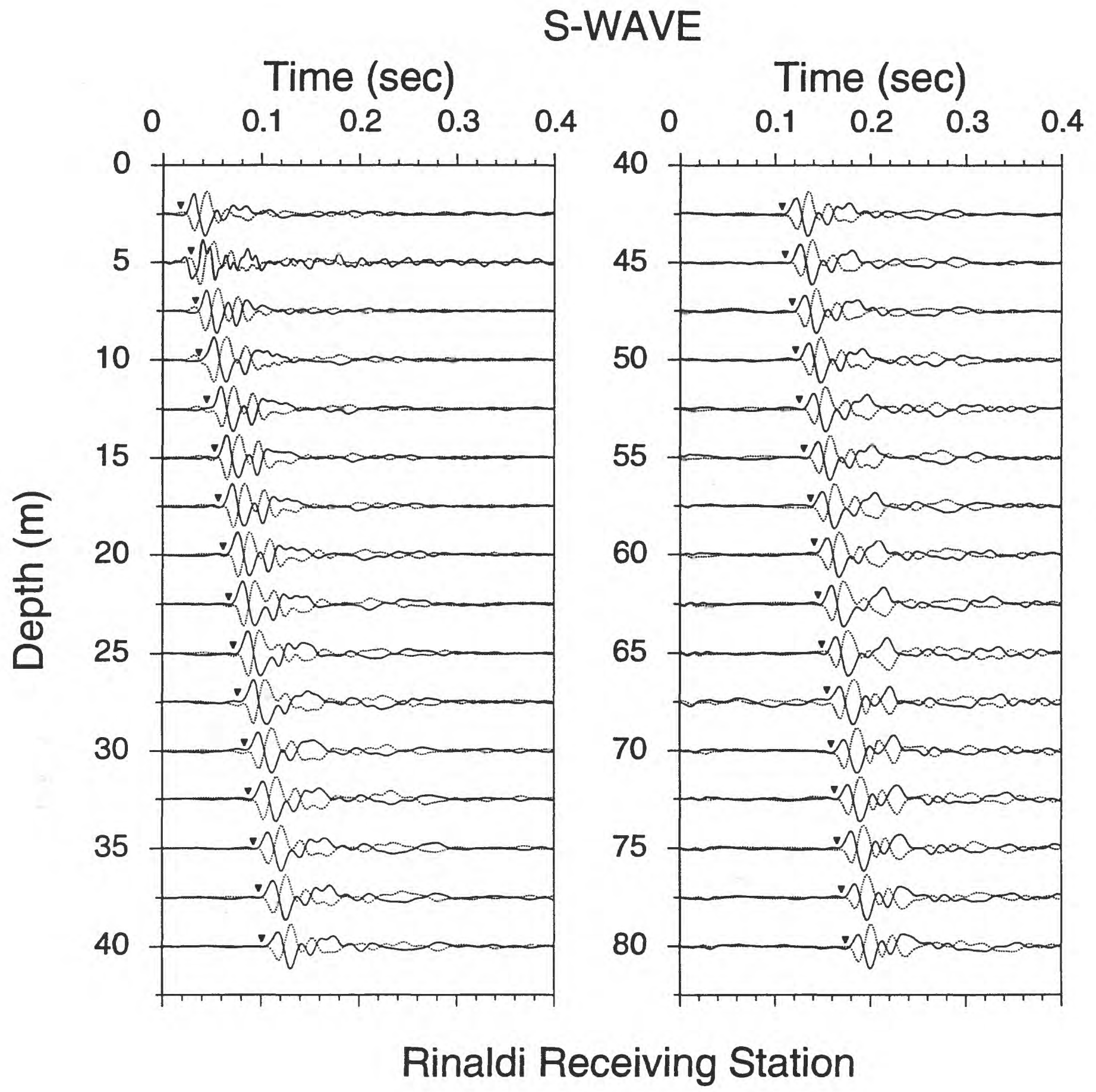

Figure 41. Horizontal component record section (from impacts in opposite directions) superimposed for identification of S-wave onset. Approximate S-wave time picks are indicated by the inverted triangles. 


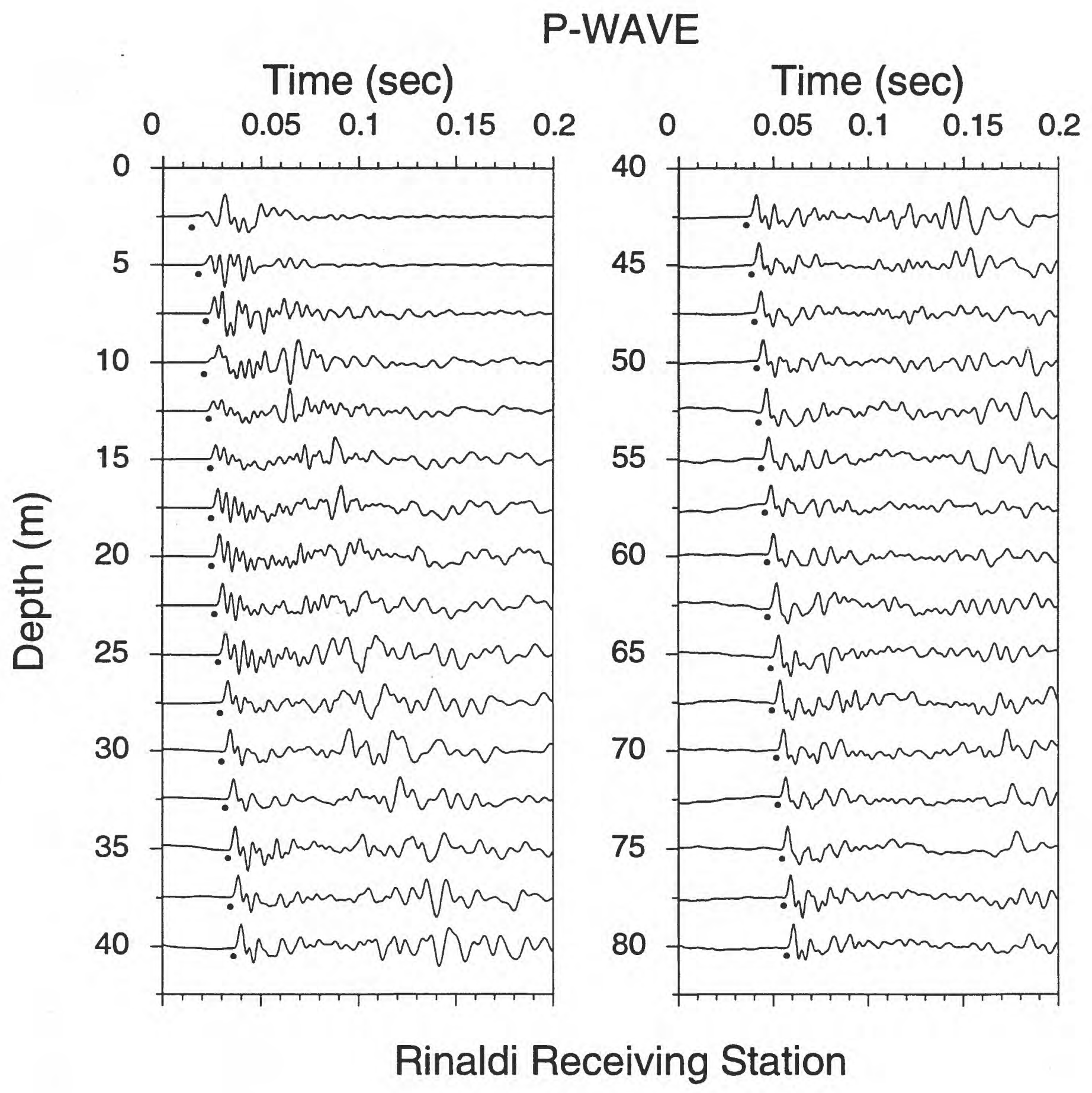

Figure 42. Vertical component record section. P-wave arrivals are indicated by the solid circles. 


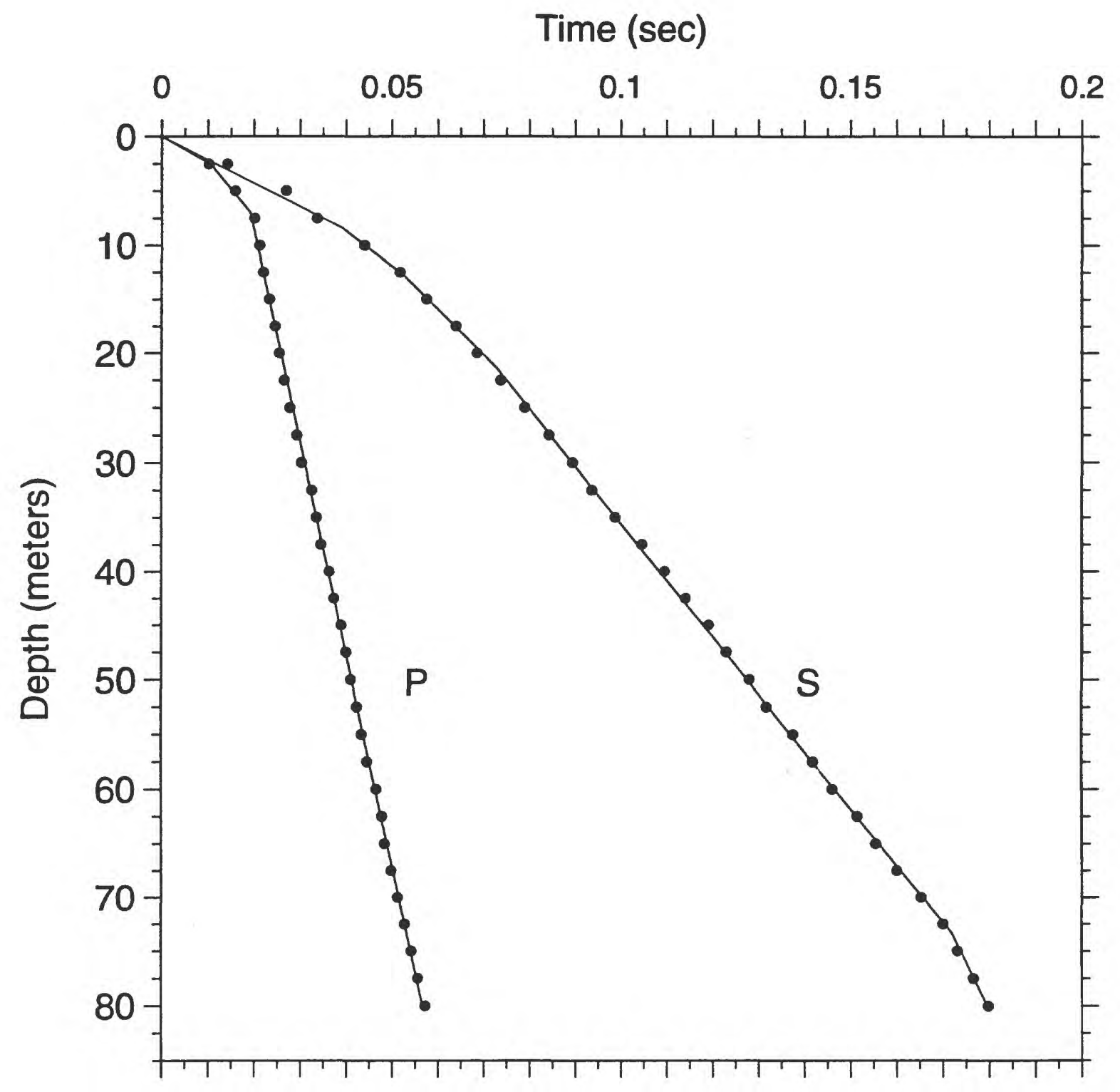

Rinaldi Receiving Station

Figure 43. Time-depth graph of $\mathrm{P}$-wave and S-wave picks. Line segments show the hinged-least-squares fit to the data points. 

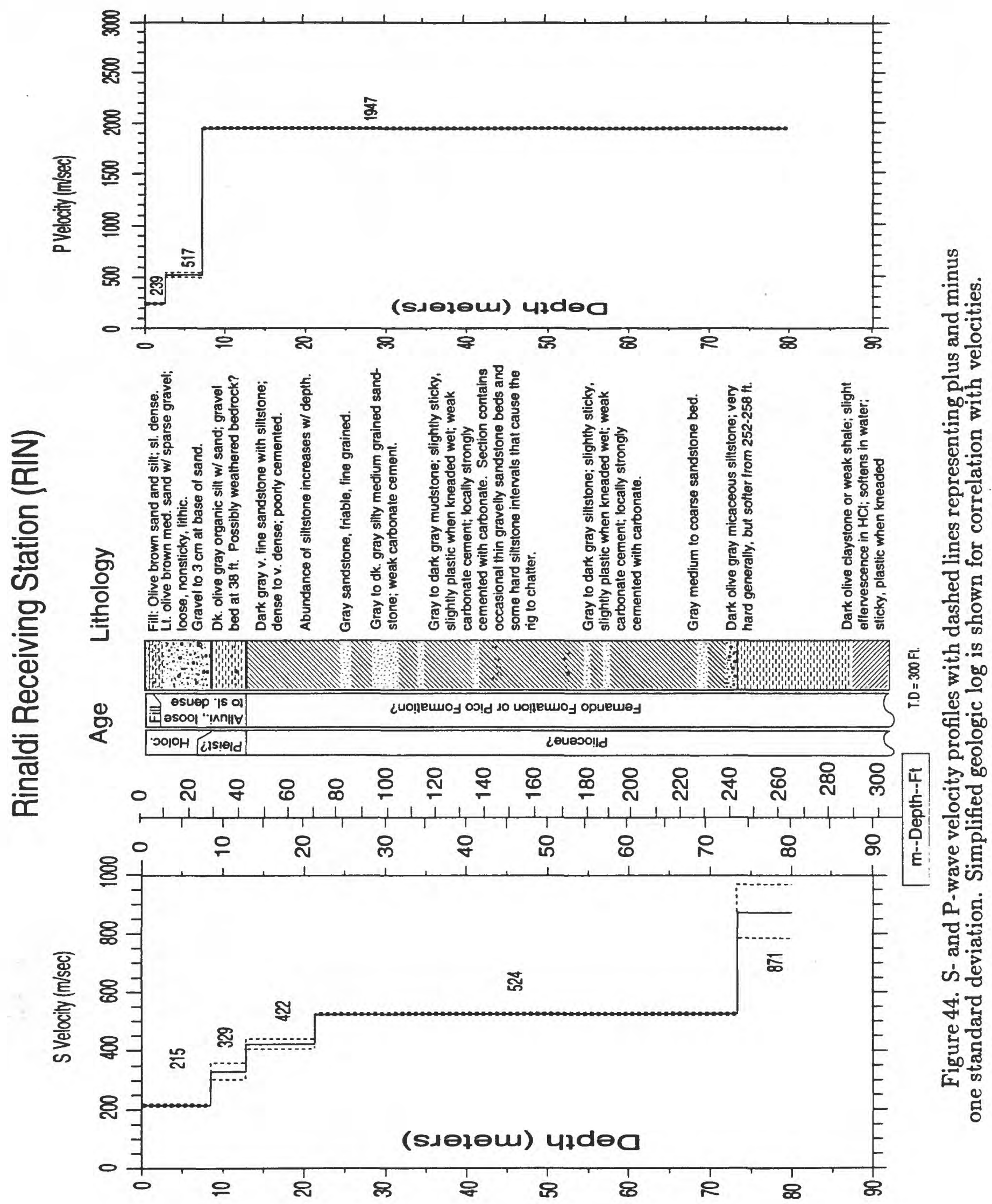
कํํำํํํํํํำ

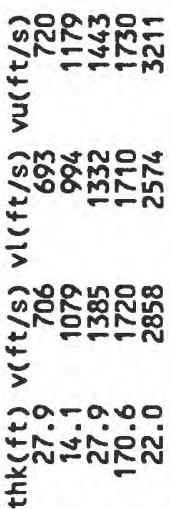

Cacain

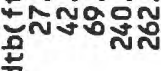

ב

พิํํำำกิ

还

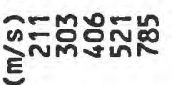

齐

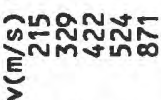

휼 댕

뱋융용

蛋

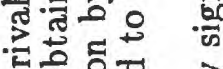

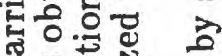

\&

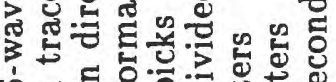

* 윰

g.

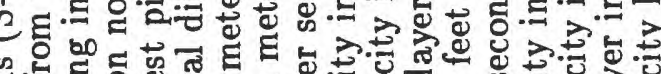

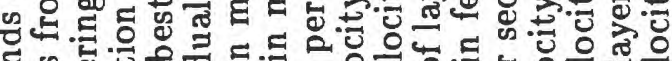
등

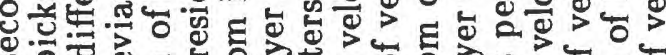

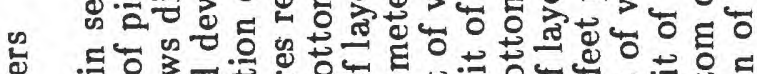

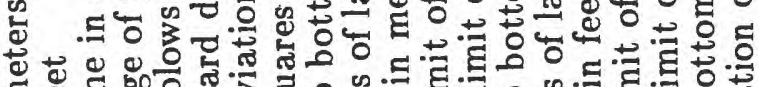

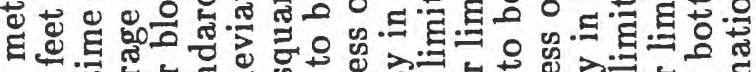

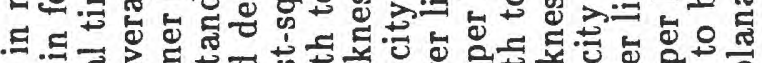
․․듀 돈돈.

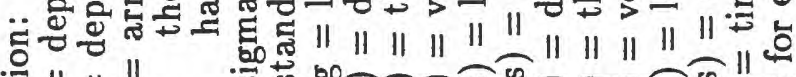

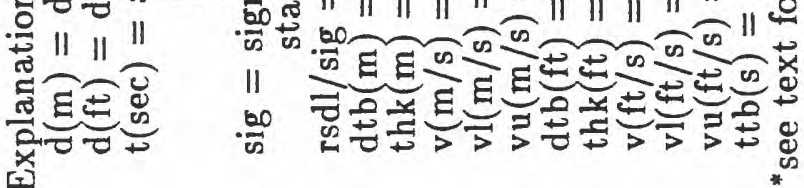

E़minon

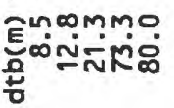

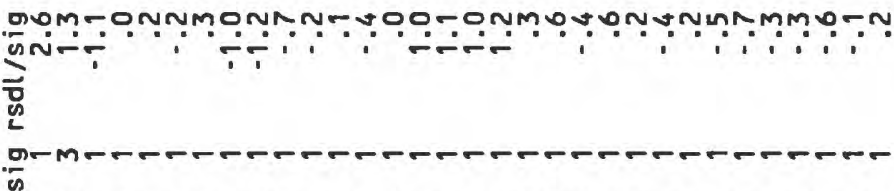

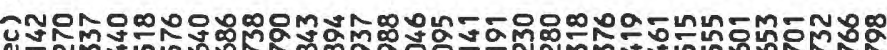

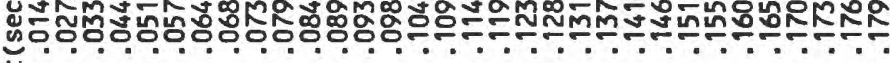

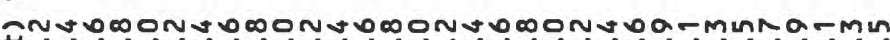

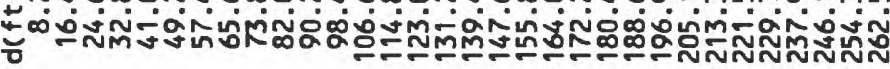

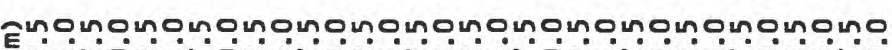

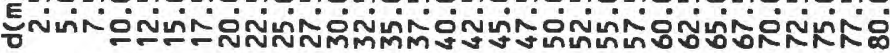


政

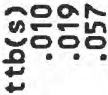

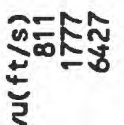

눈

屯웡응

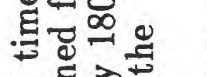

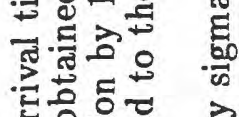

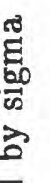

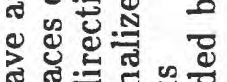

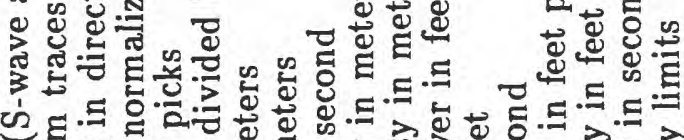

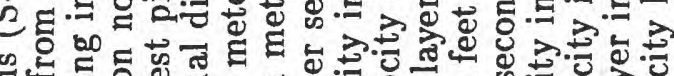

ర్

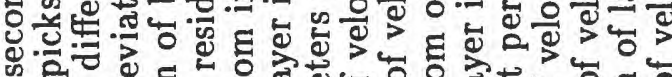

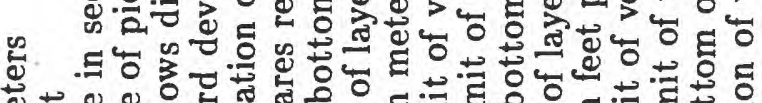
包

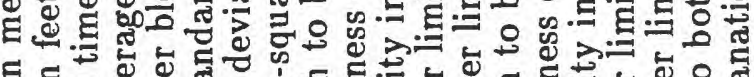

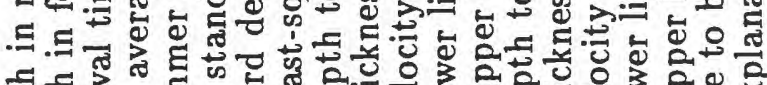
독 돈.

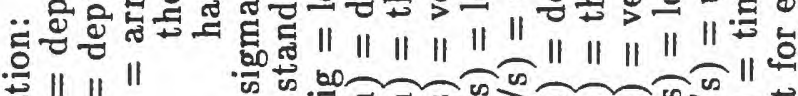

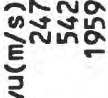

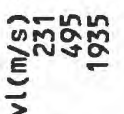

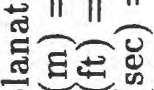
랃ㅎㄷ "⿻

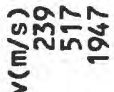
㰻

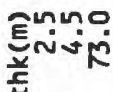

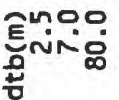

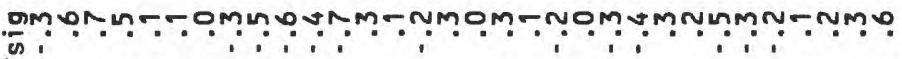

$\overrightarrow{\mathrm{w}}$

om-

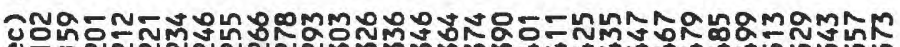

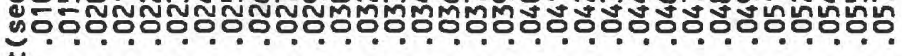

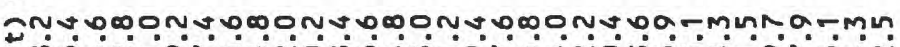

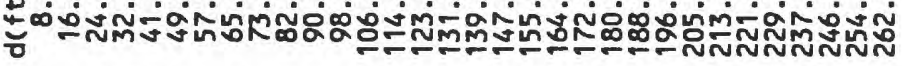
Enounonounonounonounonounononononounono

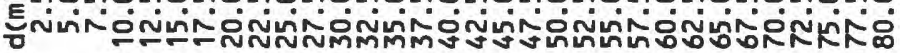




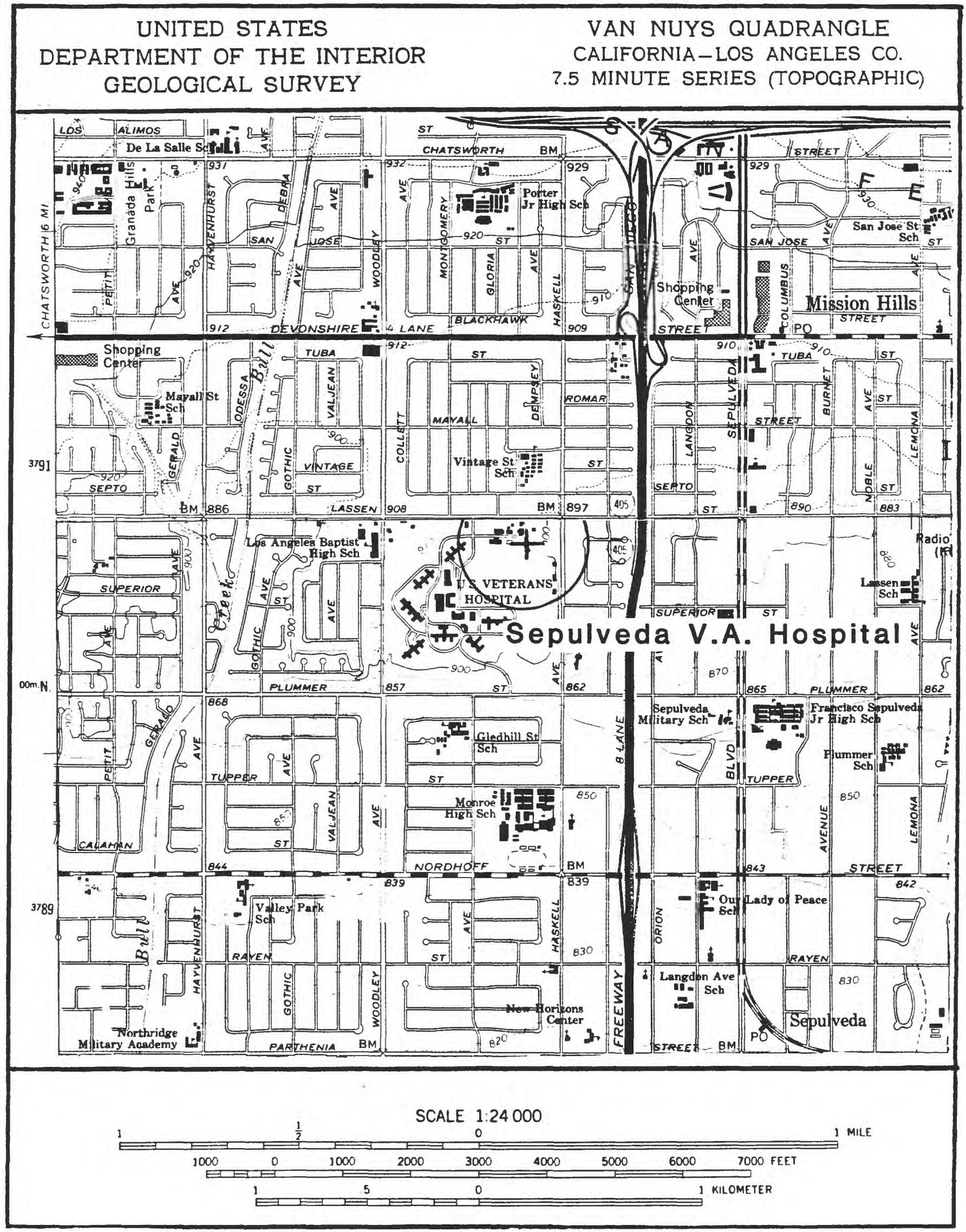

Figure 45. Site location map for the borehole at Sepulveda V.A. Hospital. The accelerograph is located approximately 30 meters from the borehole. 


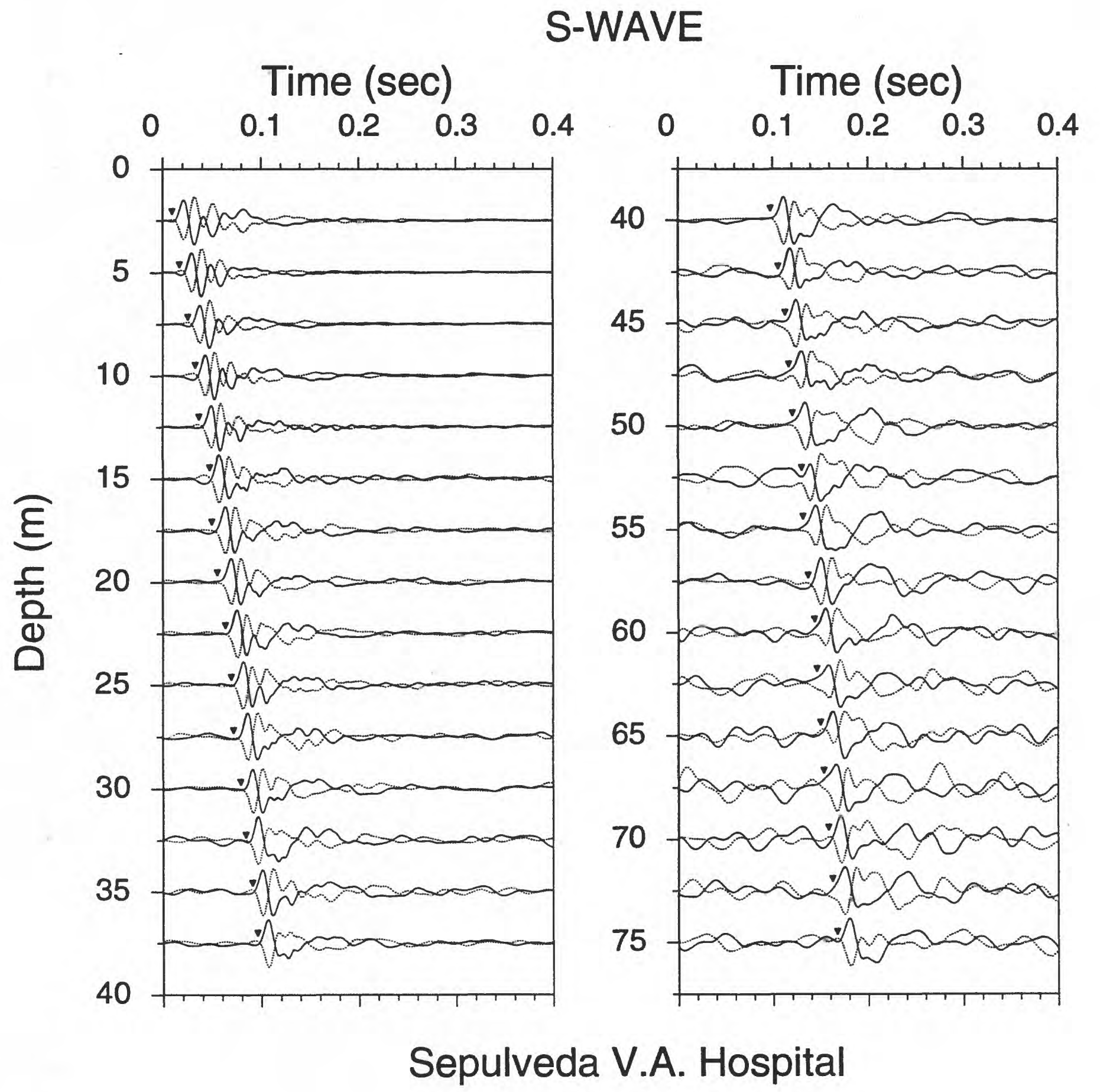

Figure 46. Horizontal component record section (from impacts in opposite directions) superimposed for identification of S-wave onset. Approximate S-wave time picks are indicated by the inverted triangles. 


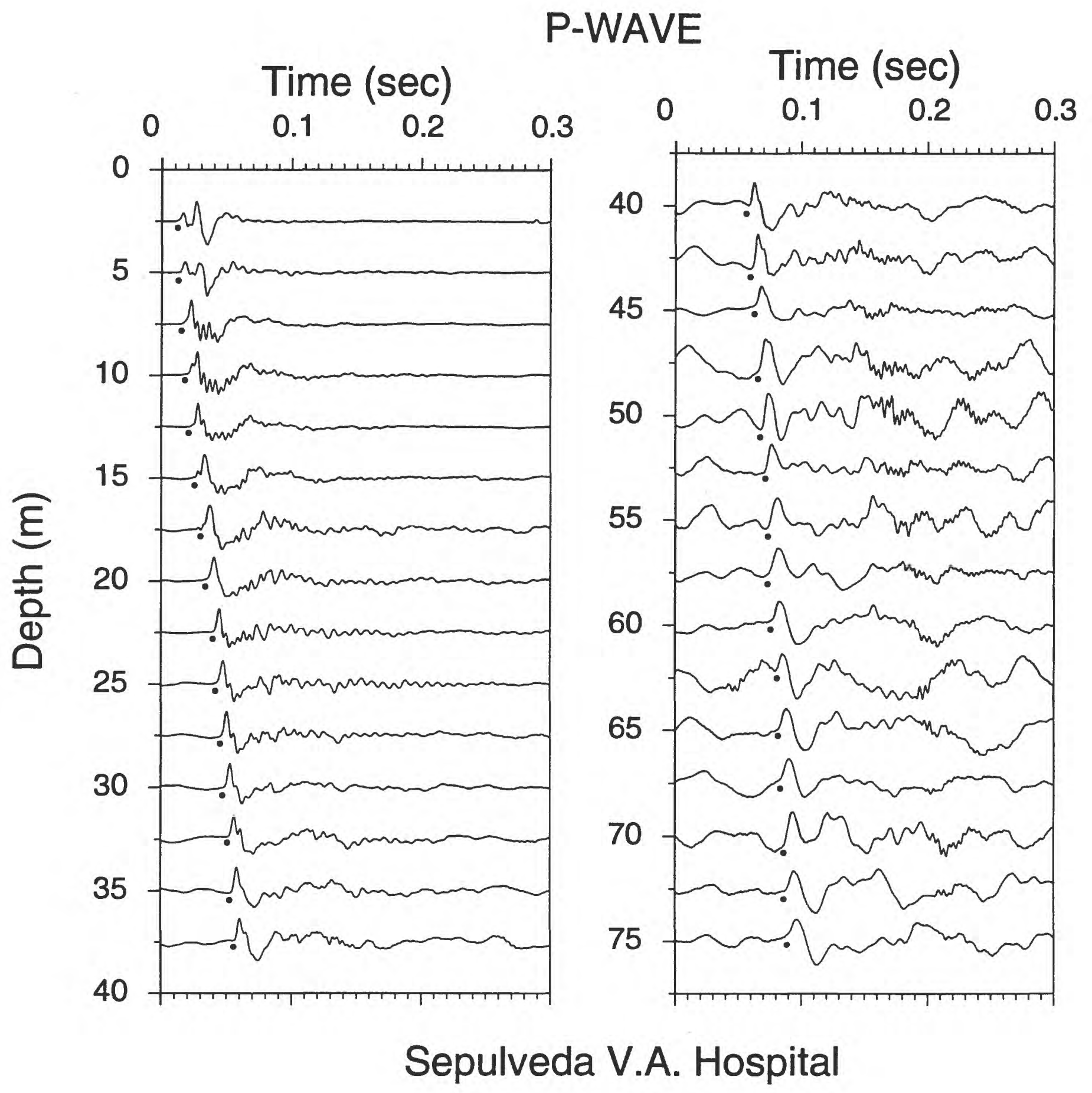

Figure 47. Vertical component record section. P-wave arrivals are indicated by the solid circles. 


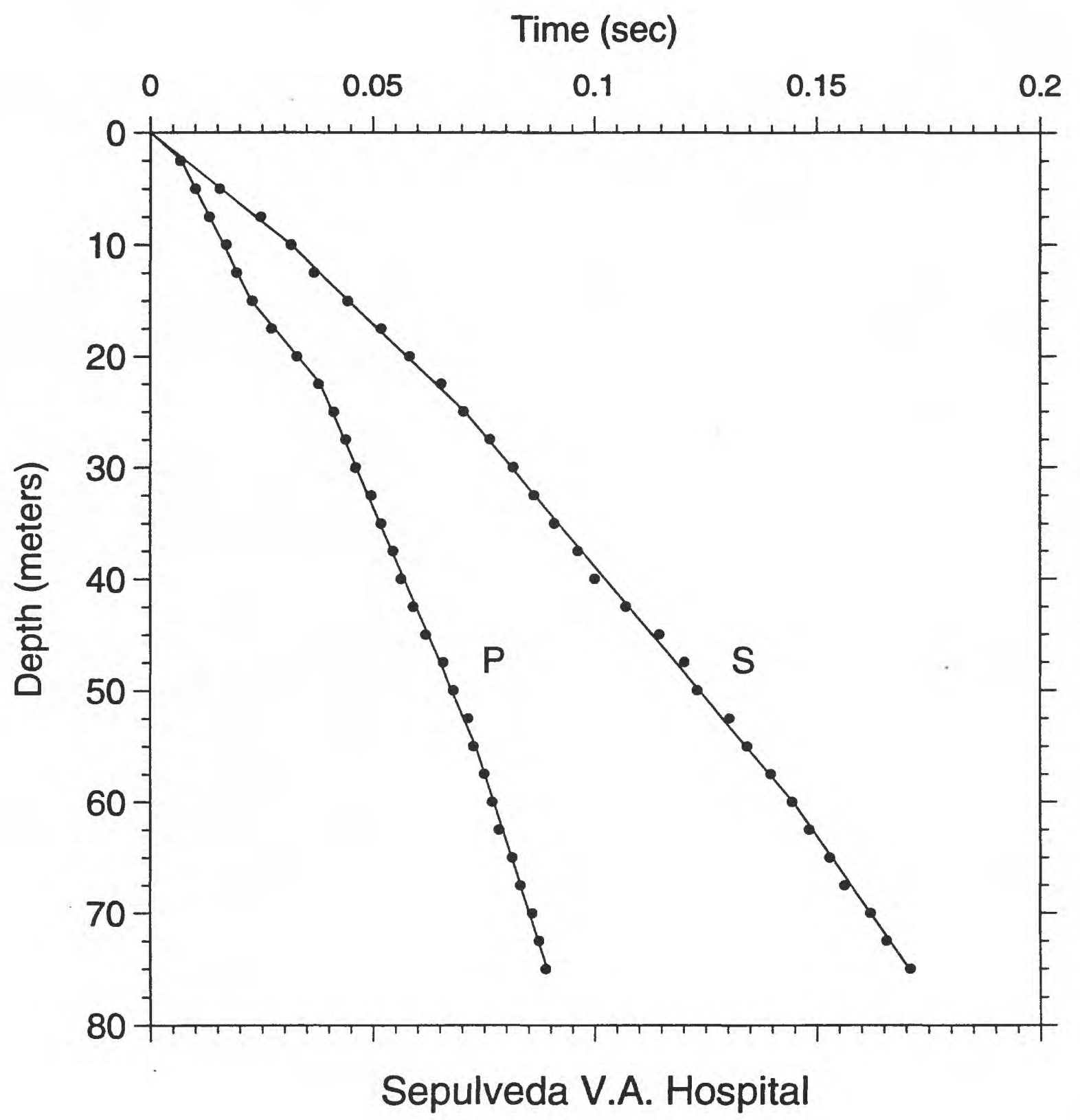

Figure 48. Time-depth graph of P-wave and S-wave picks. Line segments show the hinged-least-squares fit to the data points. 


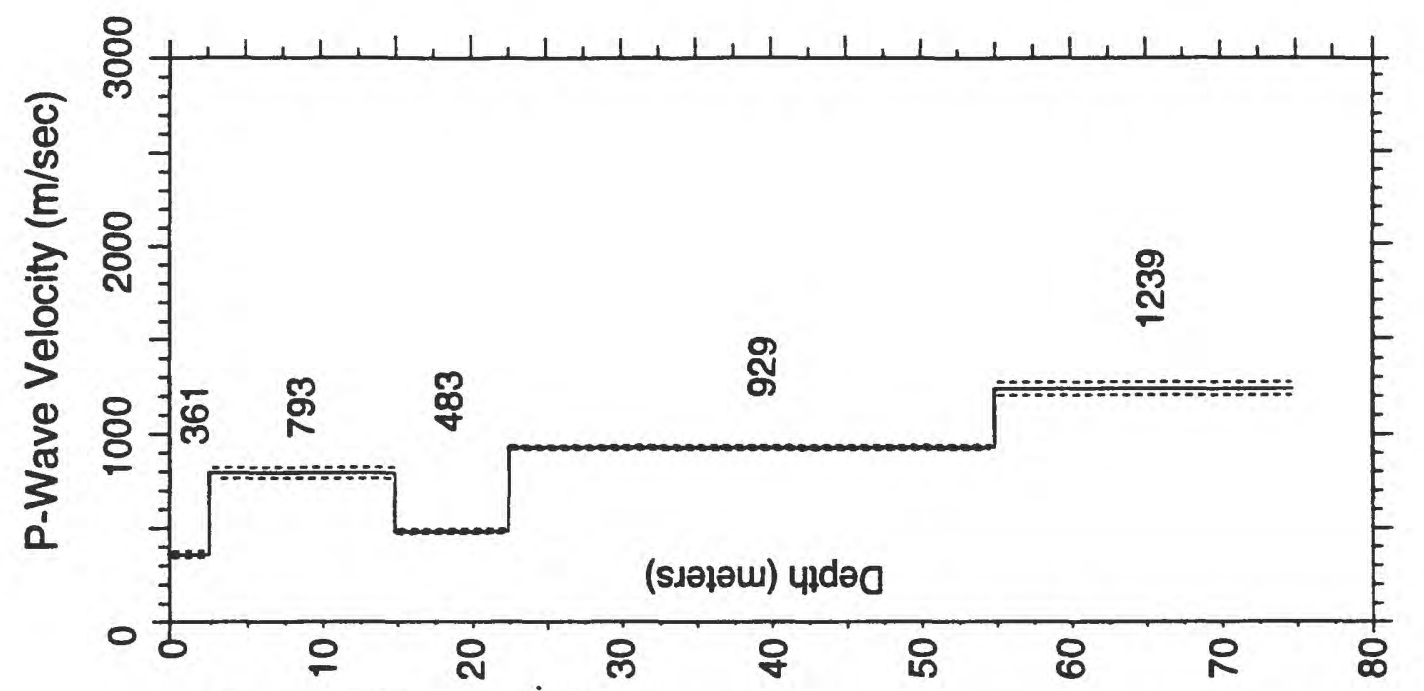

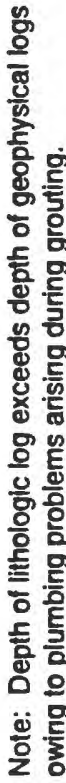
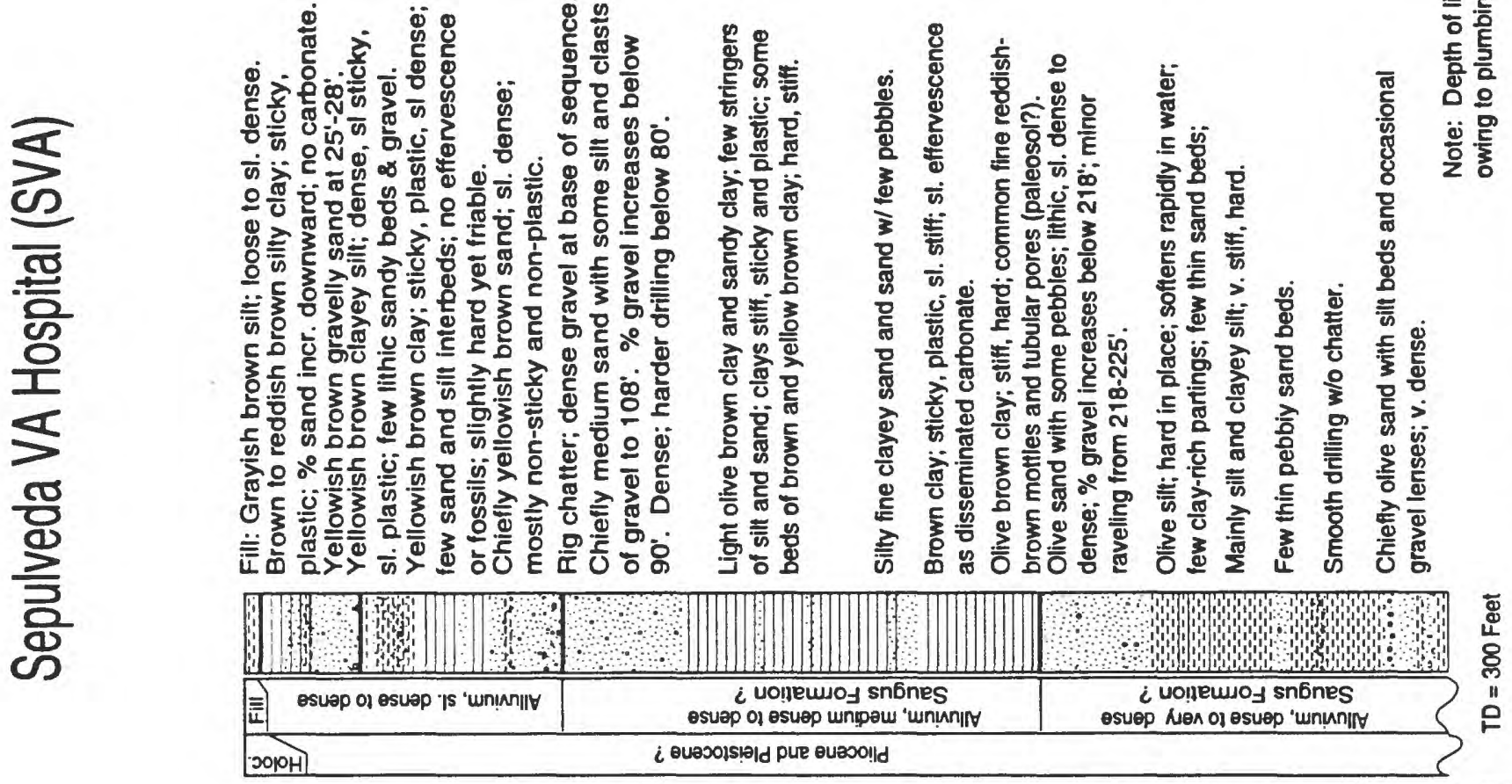

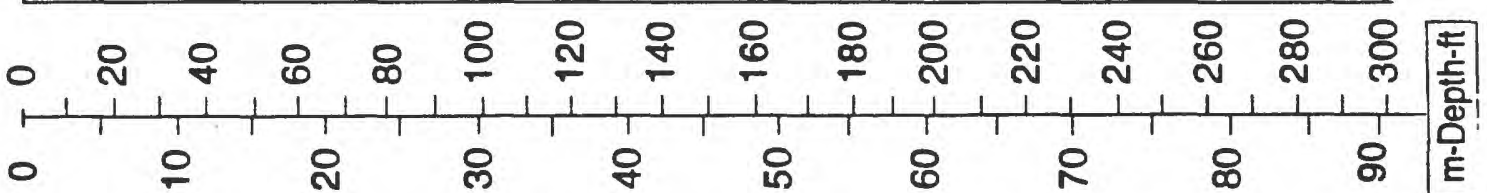

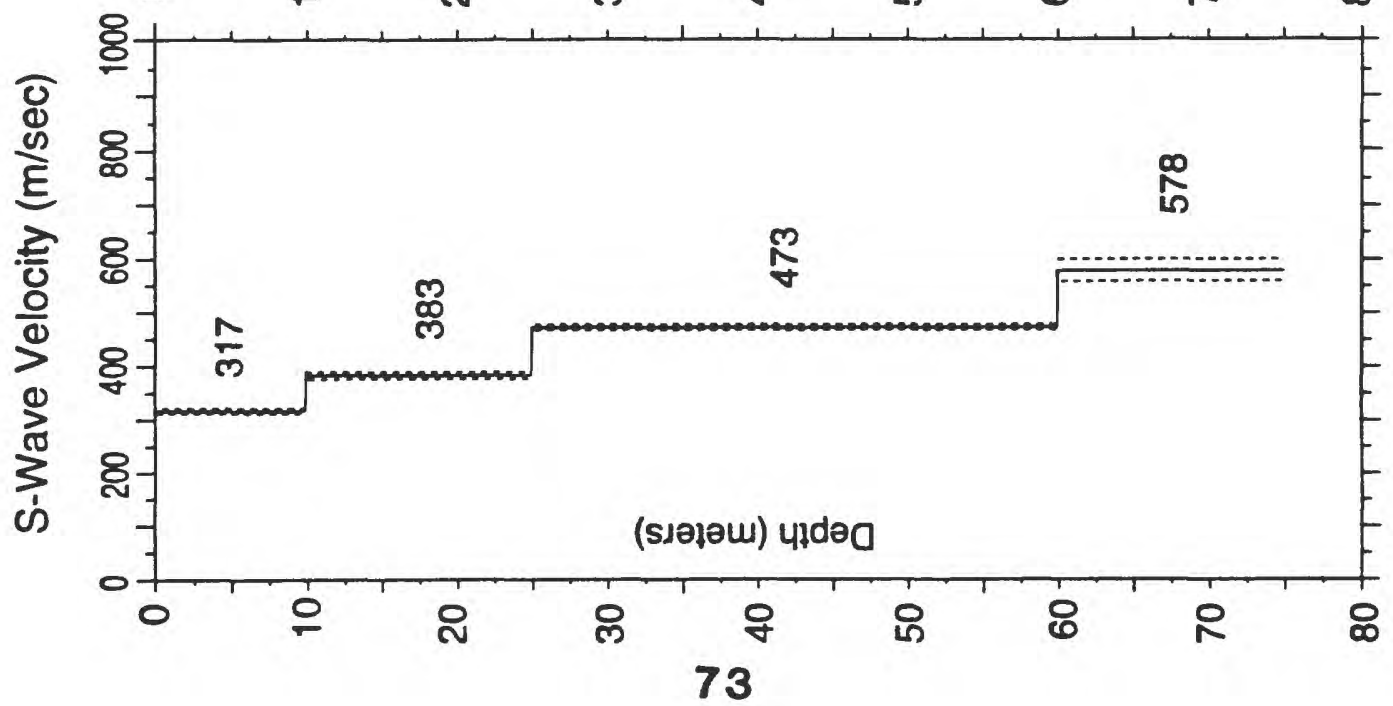

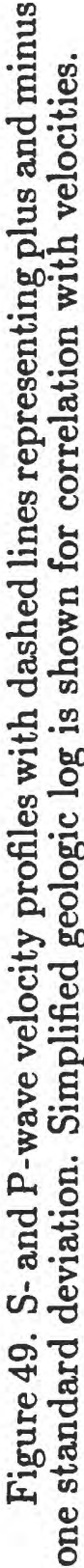


อิำำำกำ

วับํํำ

$\stackrel{0}{\frac{0}{\omega}}$

넌

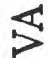



$\stackrel{8}{3}$

ผ

ఫ

莒

递

త్ర

总

능

5

옹

\&

ह્

तై

㚃

范

ช่

0

ज्ञ

E

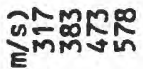

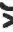

产品品品品

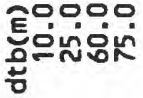
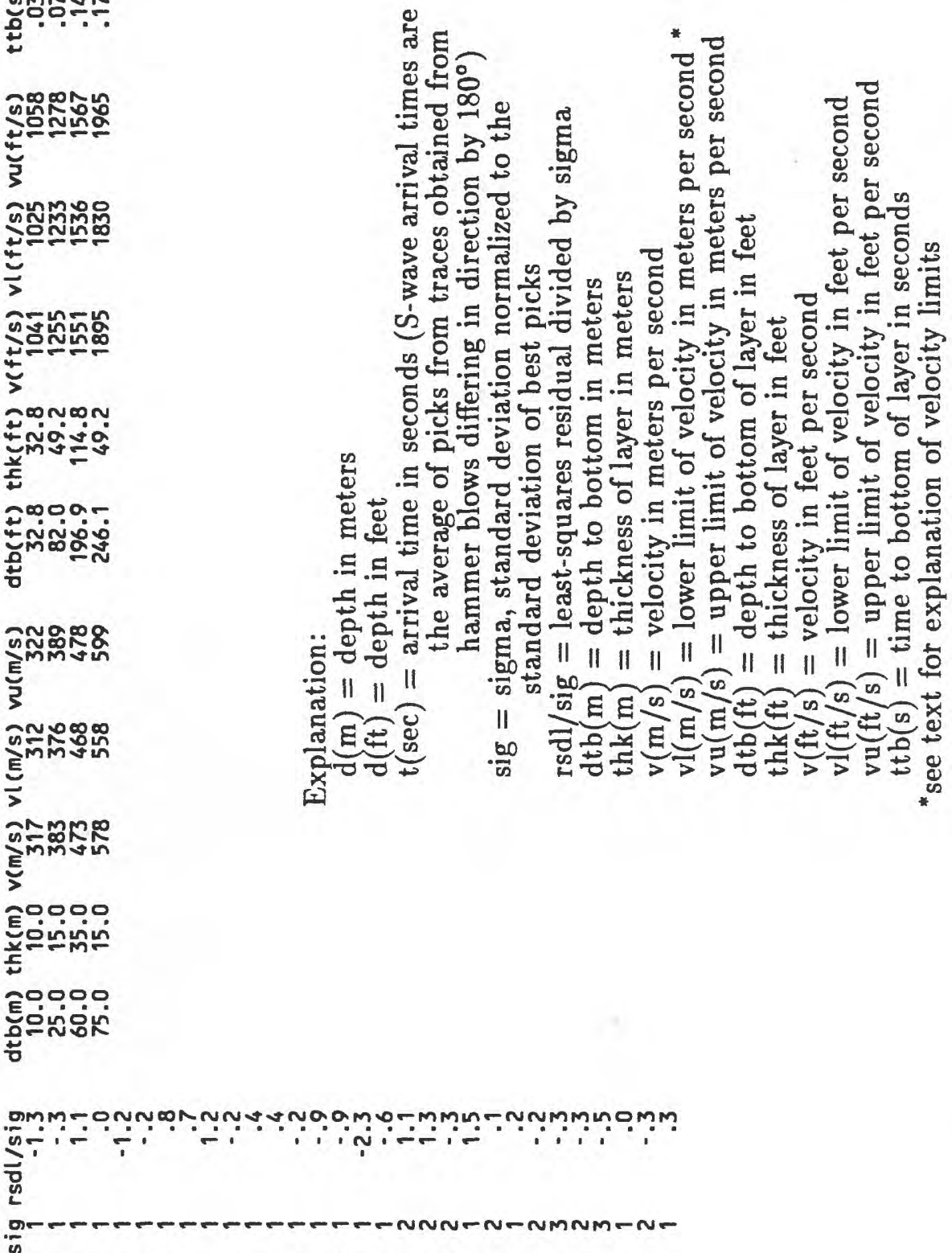

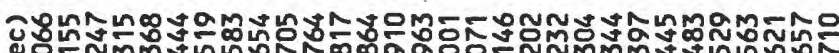

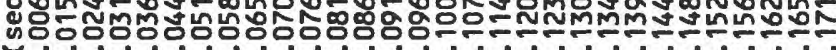

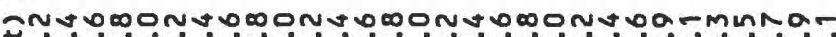

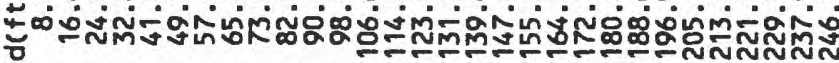

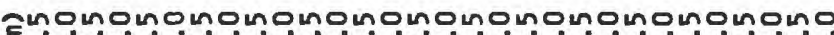

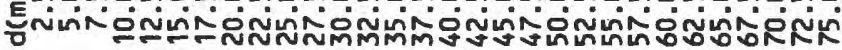




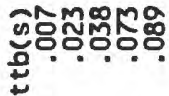

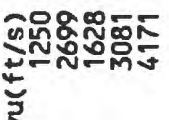

통

뚱영

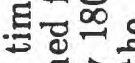

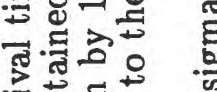

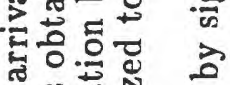

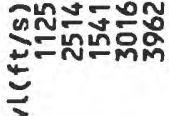

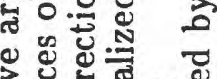

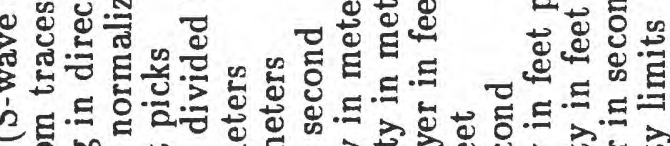

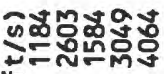
bo

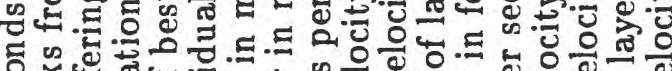

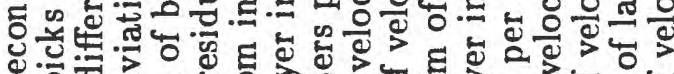

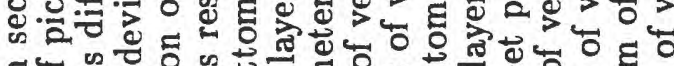

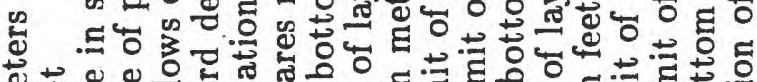

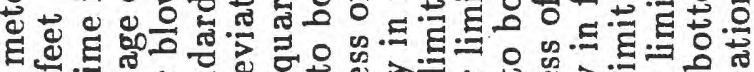

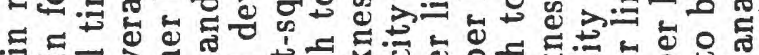

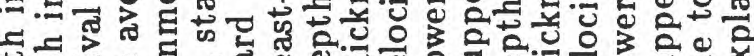

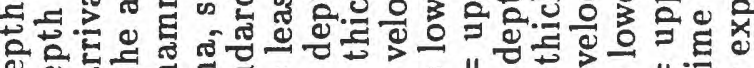

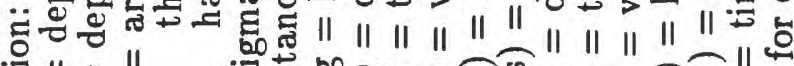

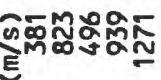
క

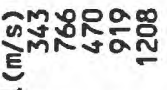
蛋

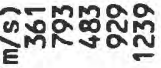

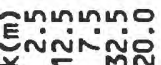
竞

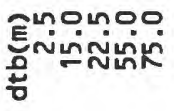

oncopobor?

के

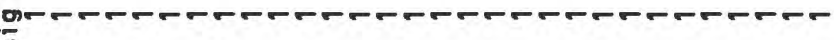

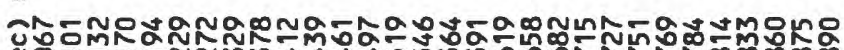

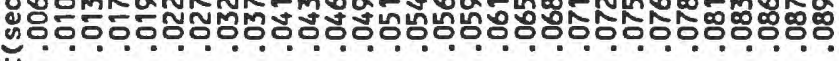

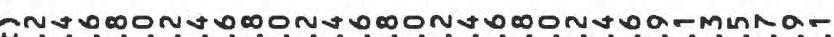

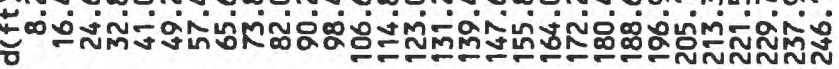
Gnonounounounounounounonounounounounonouno

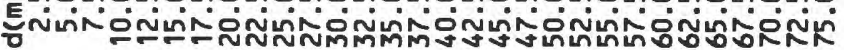




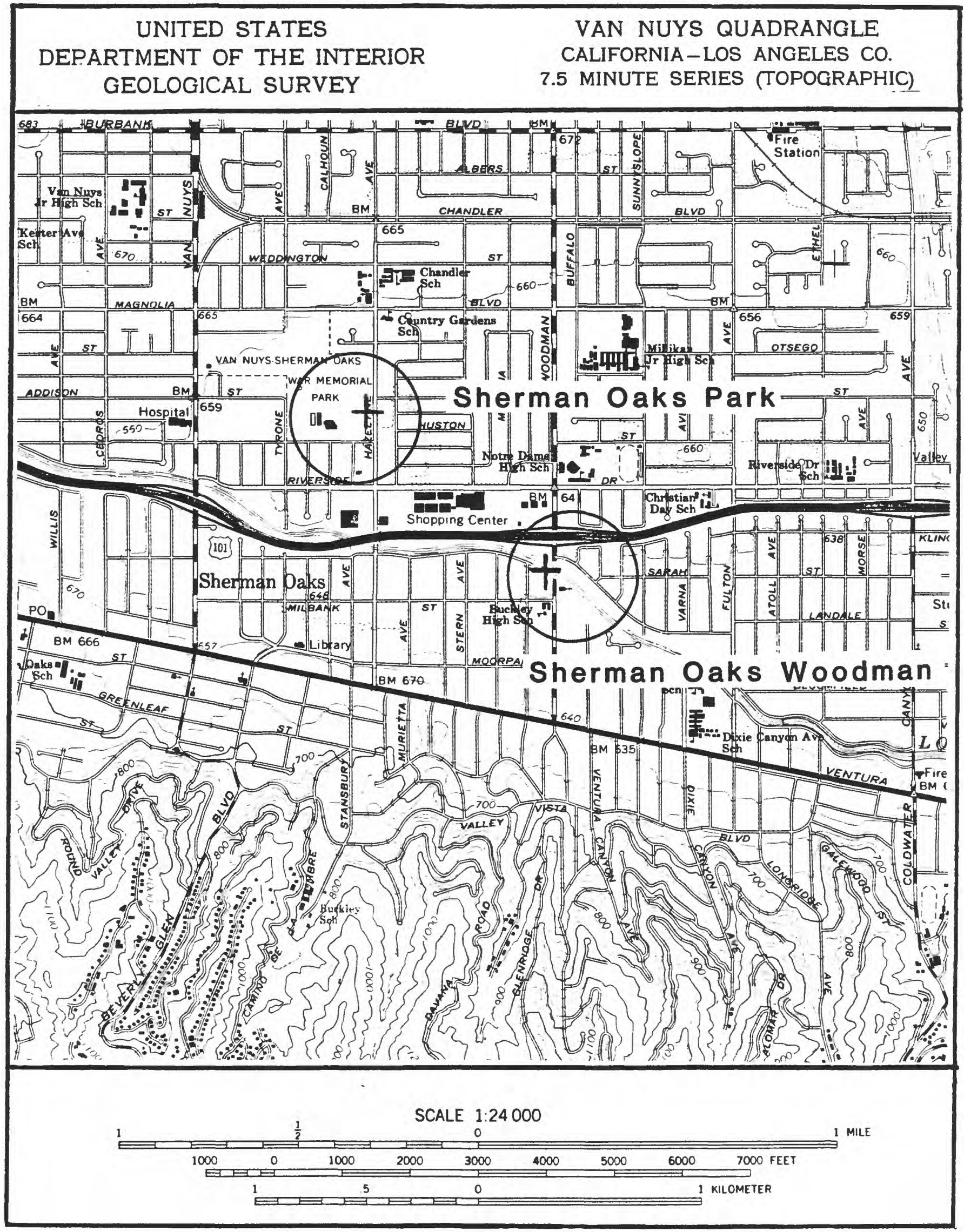

Figure 50. Site location map for the borehole at Sherman Oaks Park. No accelerograph is located at this site. 


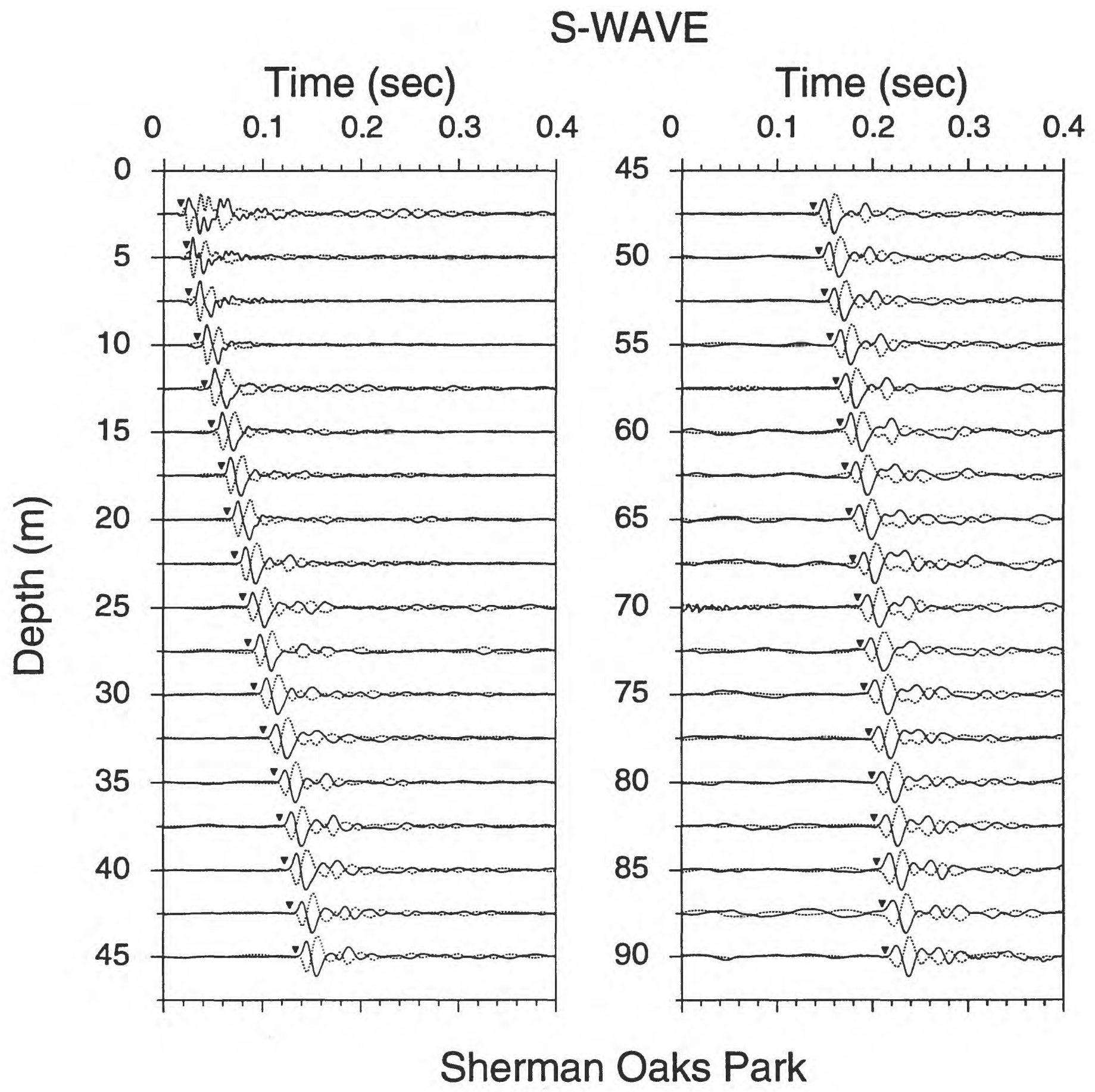

Figure 51. Horizontal component record section (from impacts in opposite directions) superimposed for identification of S-wave onset. Approximate S-wave time picks are indicated by the inverted triangles. 
P-WAVE

Time (sec)

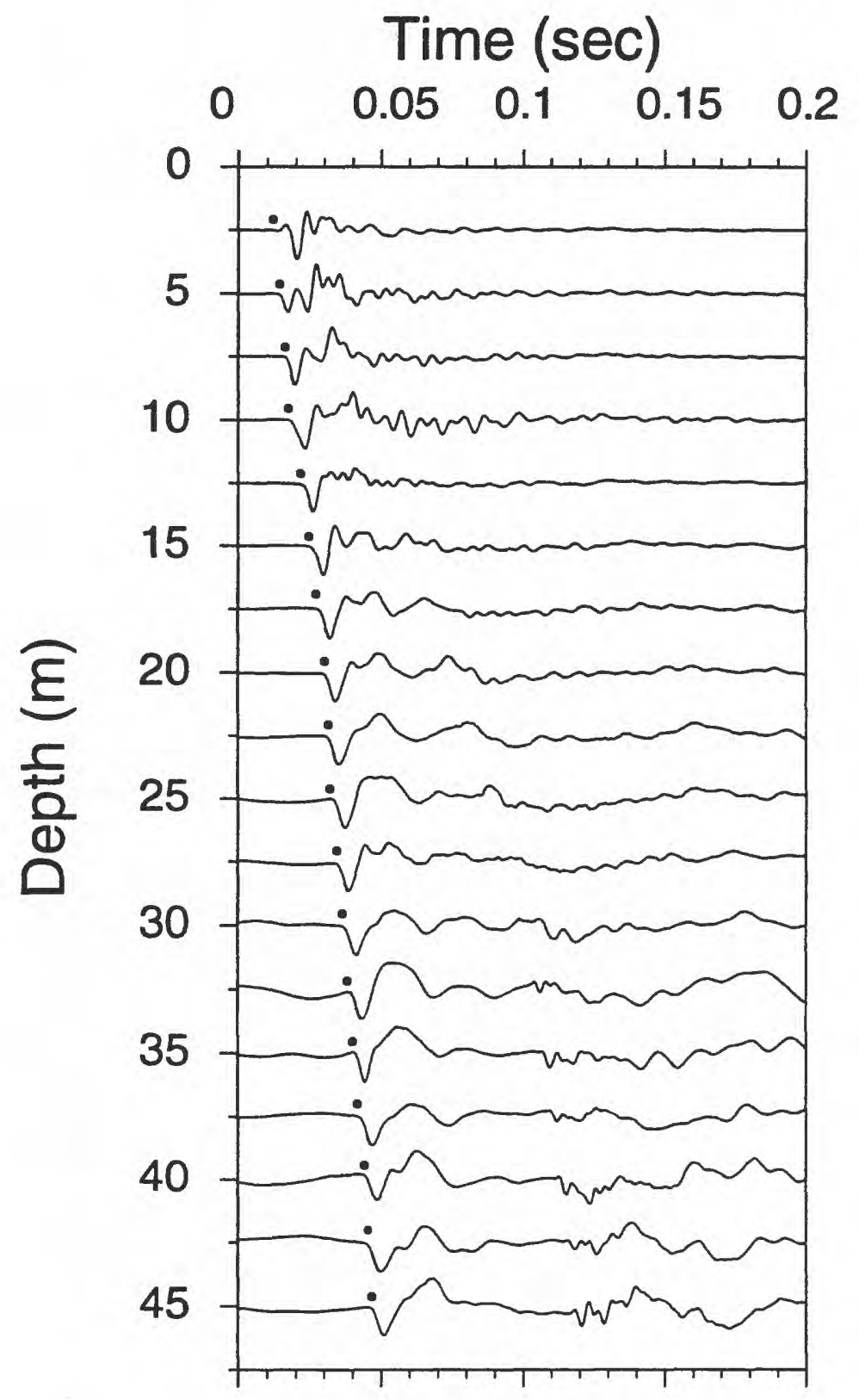

Time (sec)
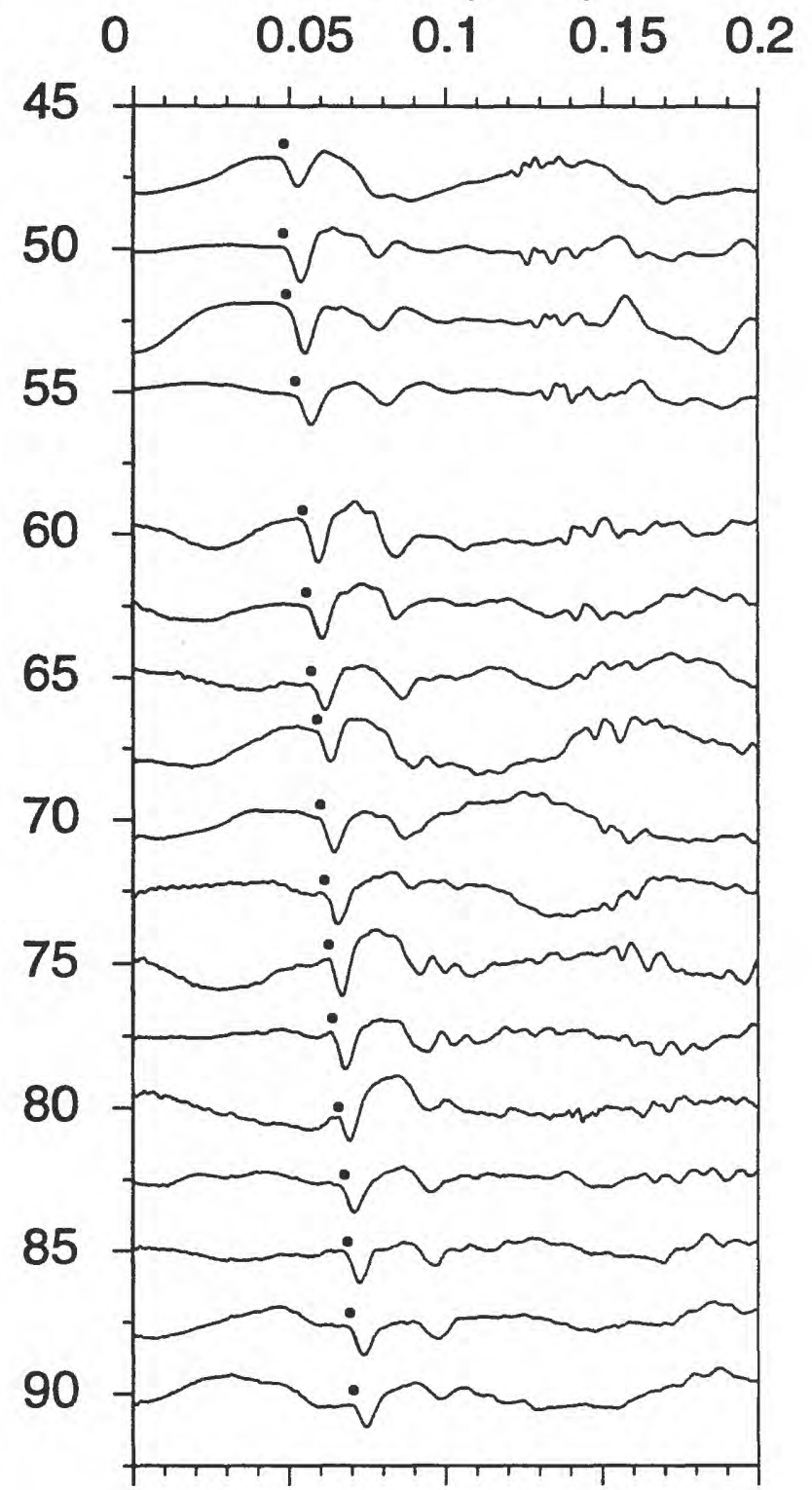

\section{Sherman Oaks Park}

Figure 52. Vertical component record section. P-wave arrivals are indicated by the solid circles. 


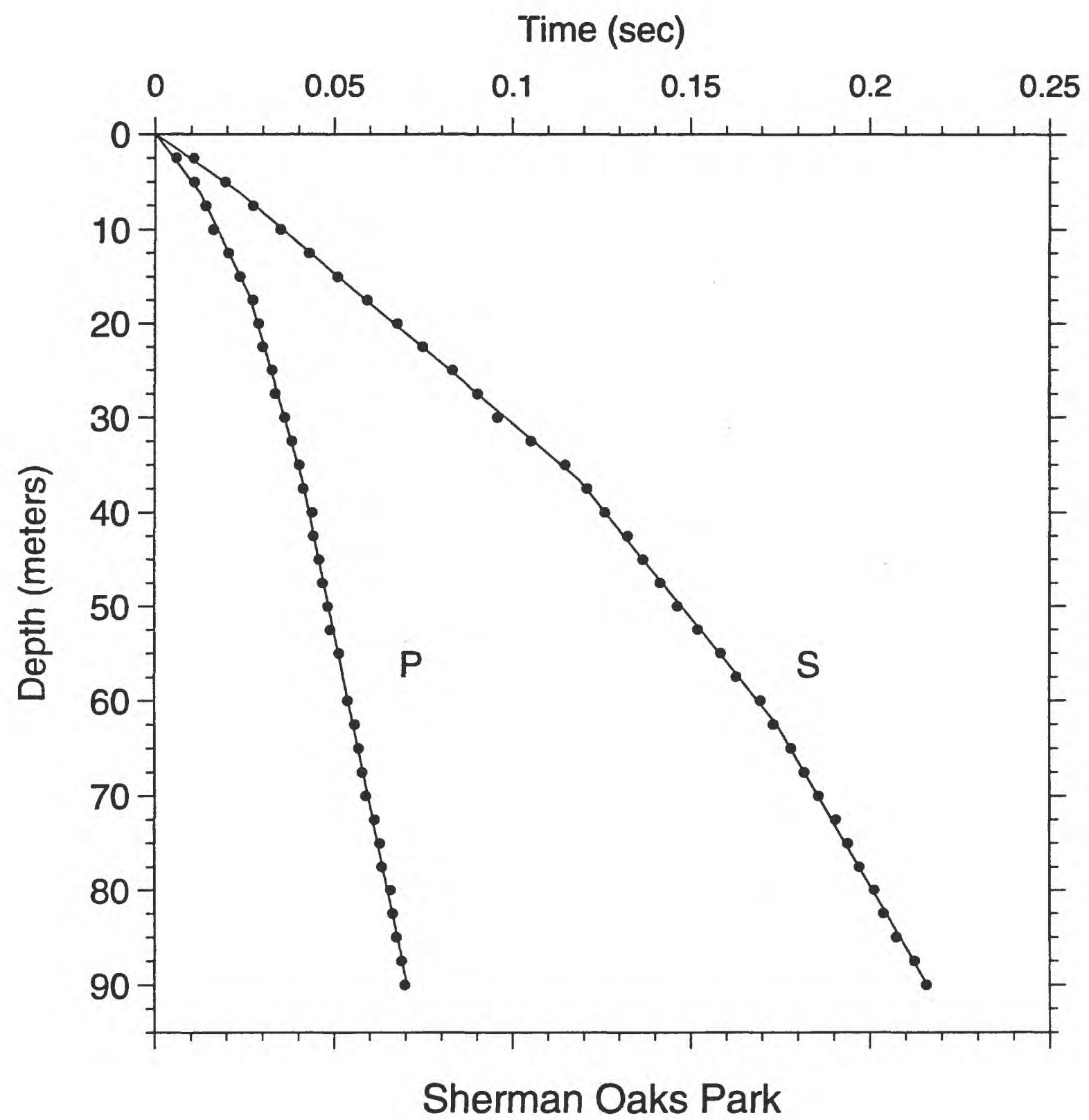

Figure 53. Time-depth graph of $\mathrm{P}$-wave and S-wave picks. Line segments show the hinged-least-squares fit to the data points. 

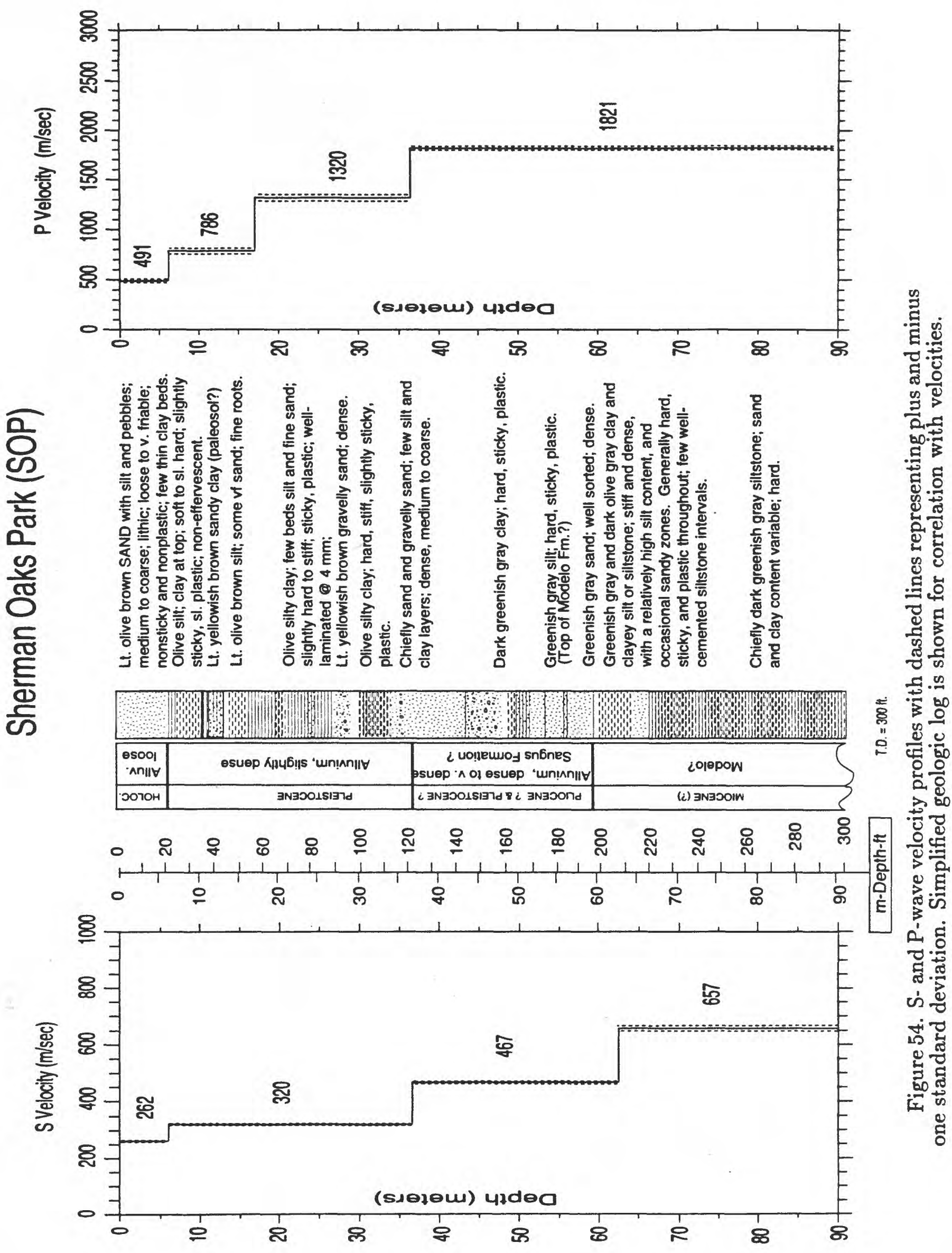
ชูํำำำำ

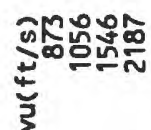

这

药

م.

輀

돌

密

थ

氠

它

.

G

㞼

$\rightarrow$

$\frac{0}{5}$

궁

(1)

.

त्व

:

$\sum_{3}^{2}$

í

$\infty$

(a)

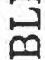

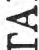

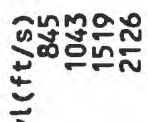

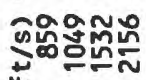
$\stackrel{4}{5}$

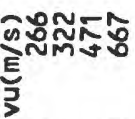

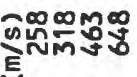
$>$ ตํํํำำ 方

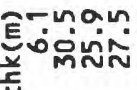

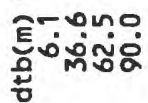

嵌

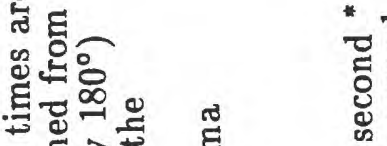

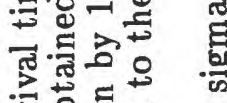

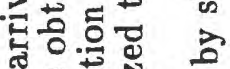

\&

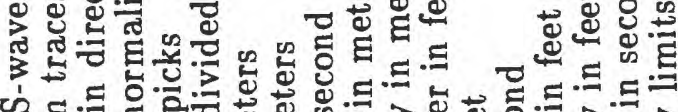
约 串结

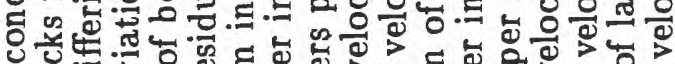

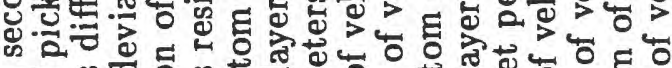

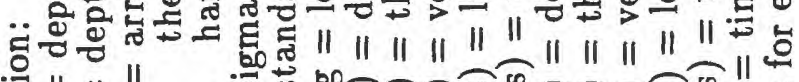

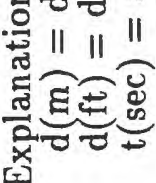

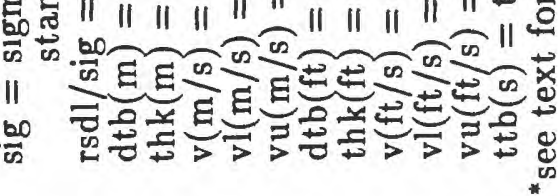

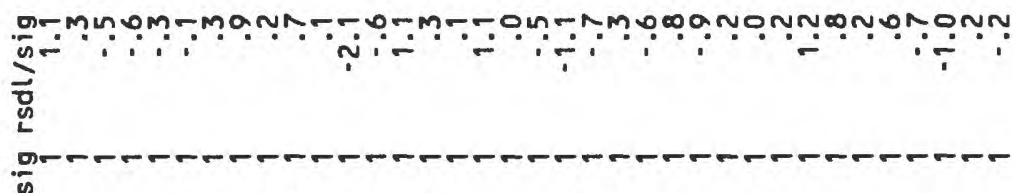

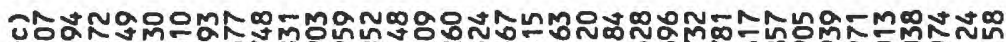

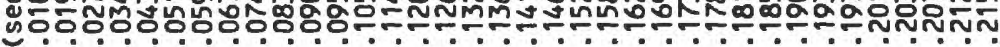
IN

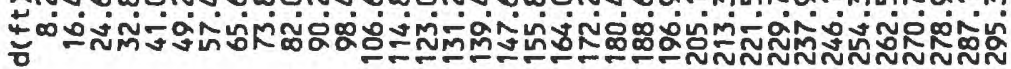

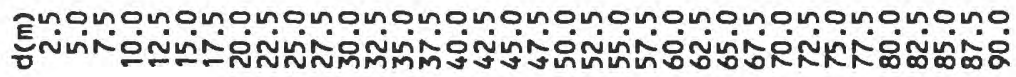


ซ్ํํํํํํํํำ

30ำ

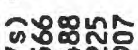

دกำำ

\)

ตะำํำ

\

somm

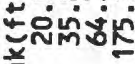

至

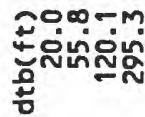

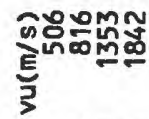

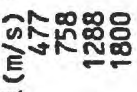

文

ธิธ์ณำ-

ตูำณ

$>$

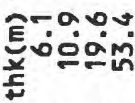

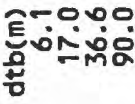

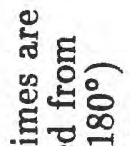

寻

곡

范

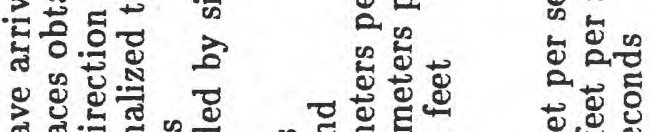

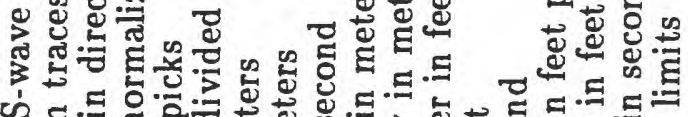

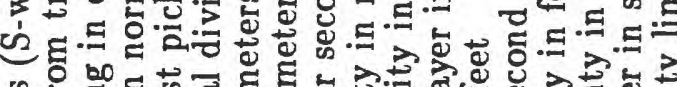

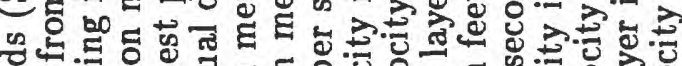

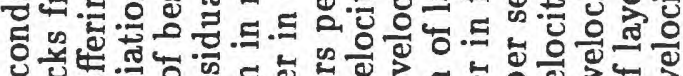

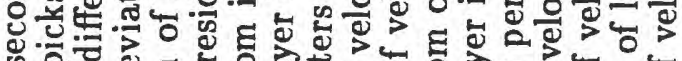
क

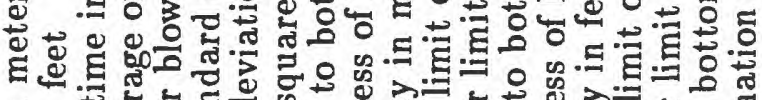

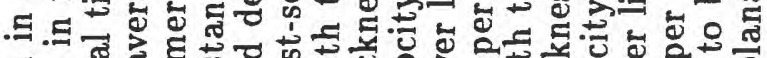
돈

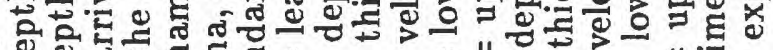

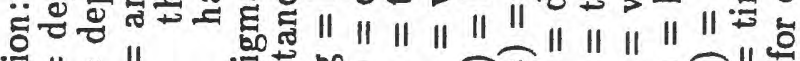

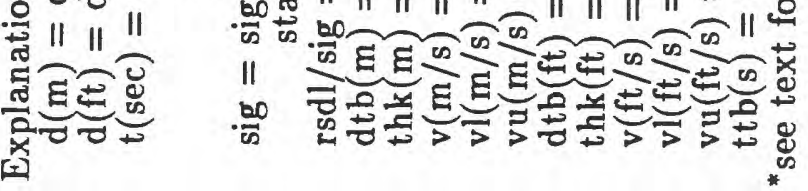

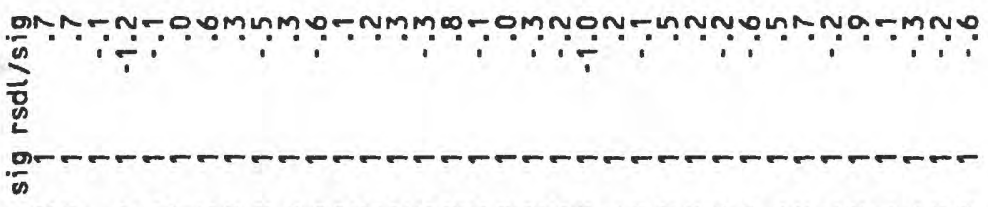

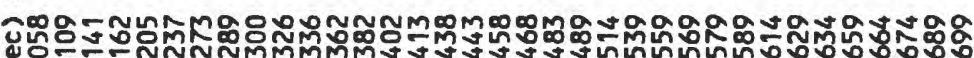

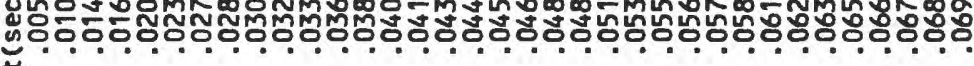

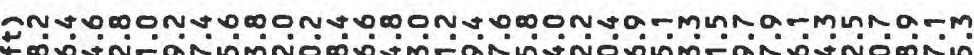

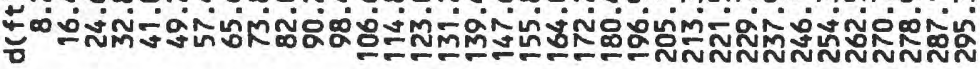

Ênounounonounounounonounonounoonounounounonono

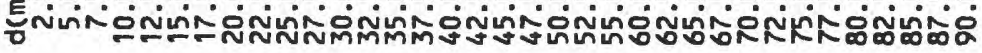




\section{UNITED STATES \\ DEPARTMENT OF THE INTERIOR GEOLOGICAL SURVEY}

\section{VAN NUYS QUADRANGLE \\ CALIFORNIA-LOS ANGELES CO.}

7.5 MINUTE SERIES (TOPOGRAPHIC)

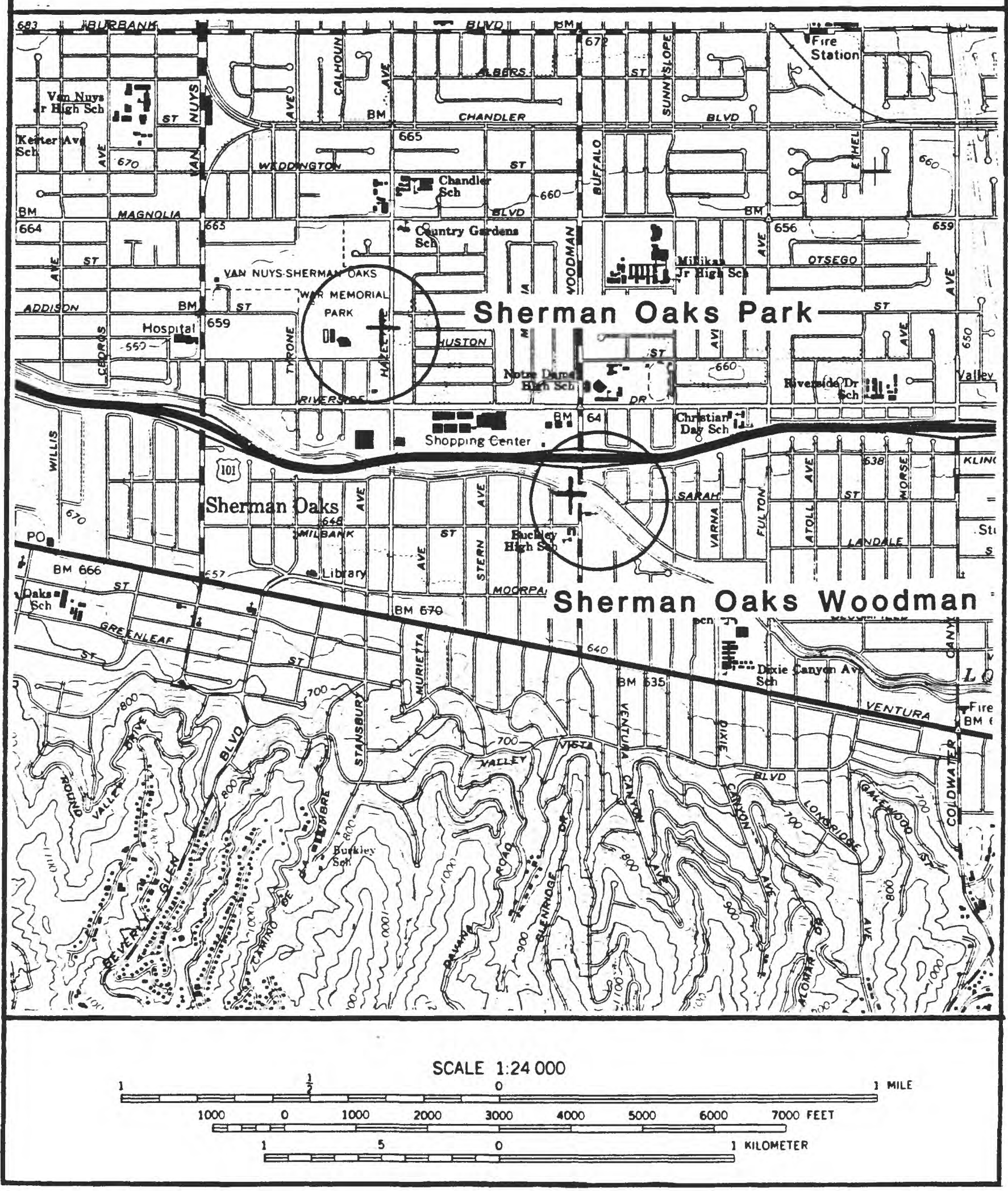

Figure 55. Site location map for the borehole at Sherman Oaks Woodman. No accelerograph is located at this site. 


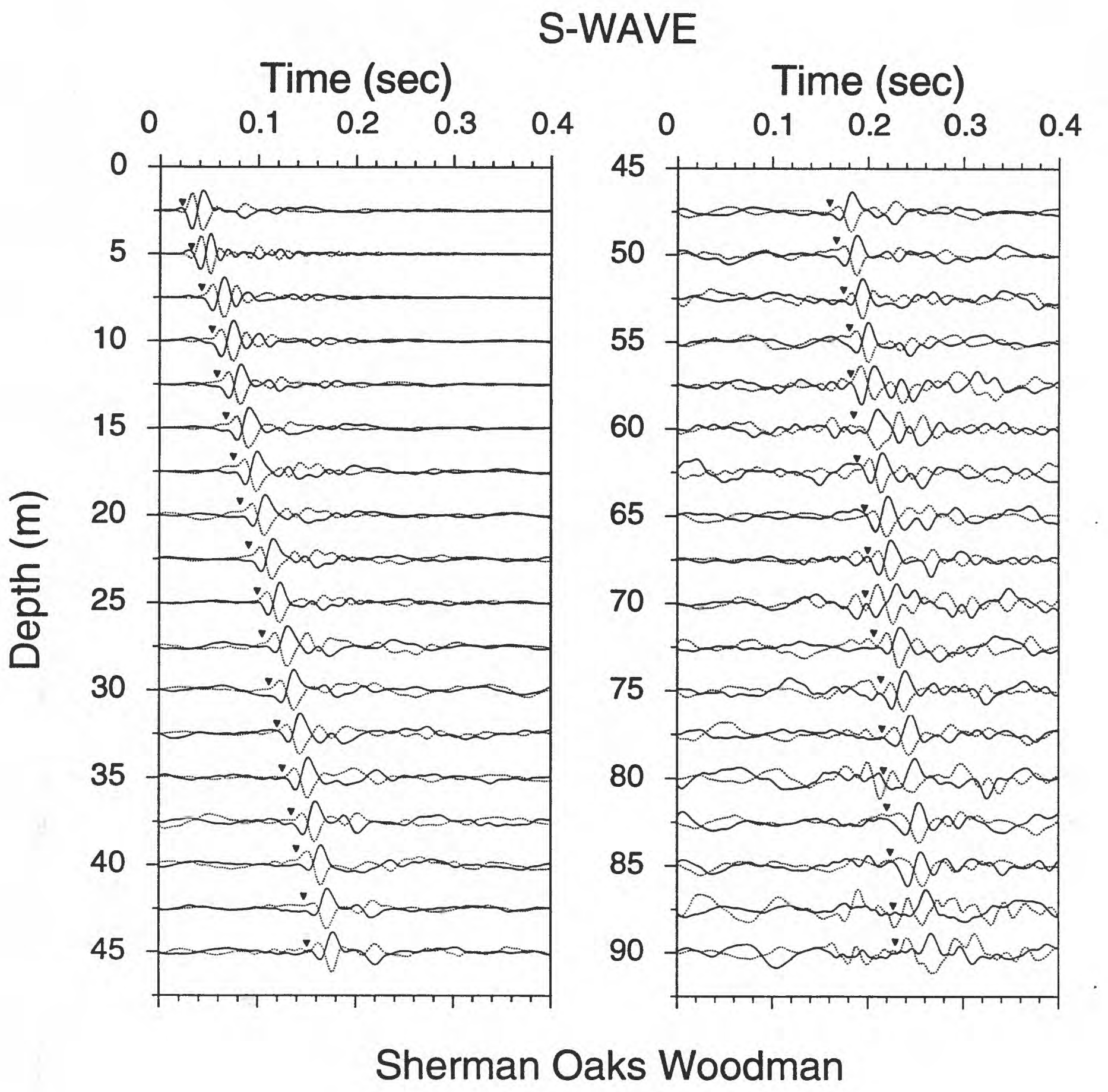

Figure 56. Horizontal component record section (from impacts in opposite directions) superimposed for identification of S-wave onset. Approximate S-wave time picks are indicated by the inverted triangles. 


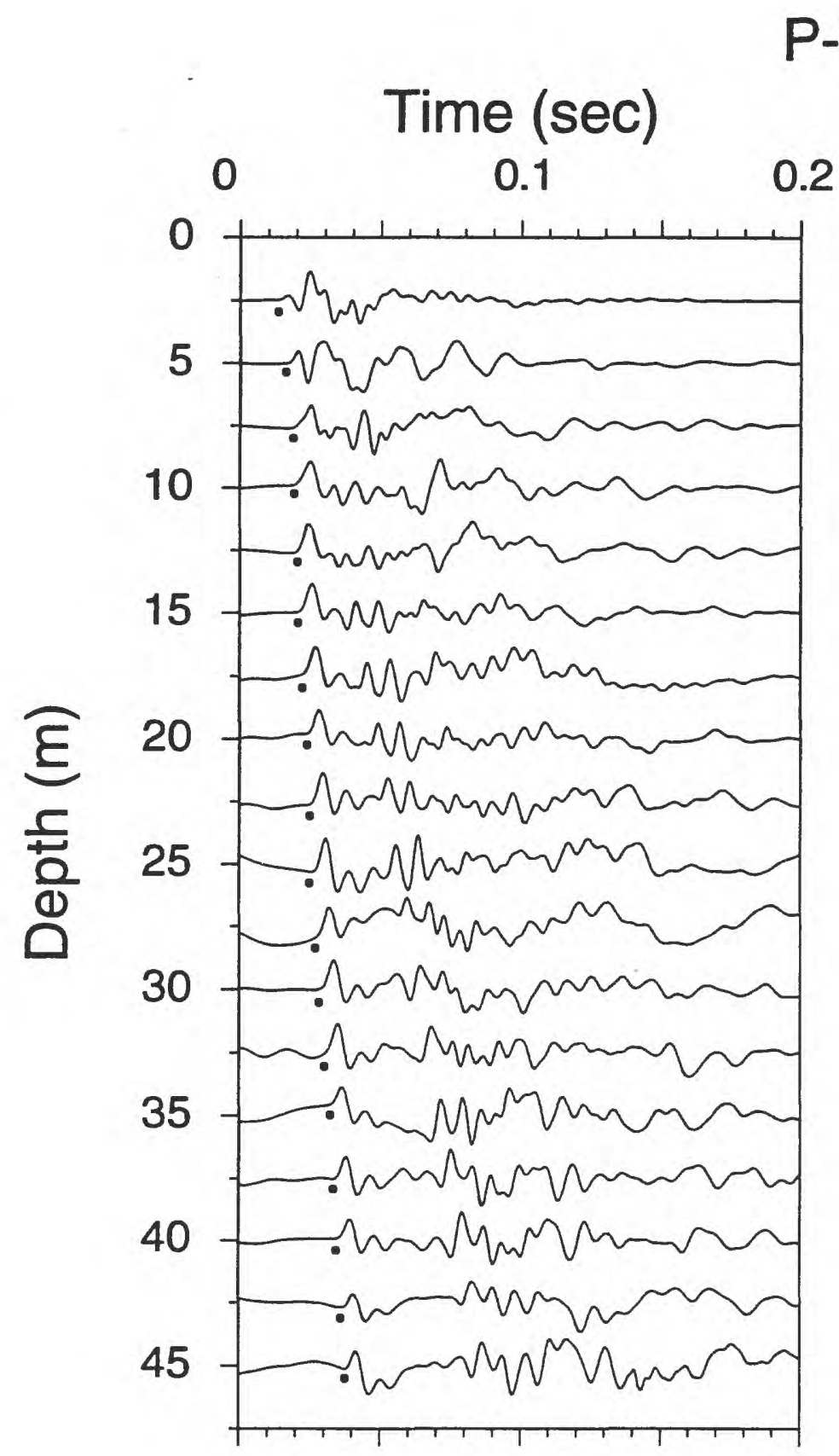

P-WAVE

Time (sec)

Time (sec)

$\begin{array}{llll}0.2 & 0 & 0.1 & 0.2\end{array}$

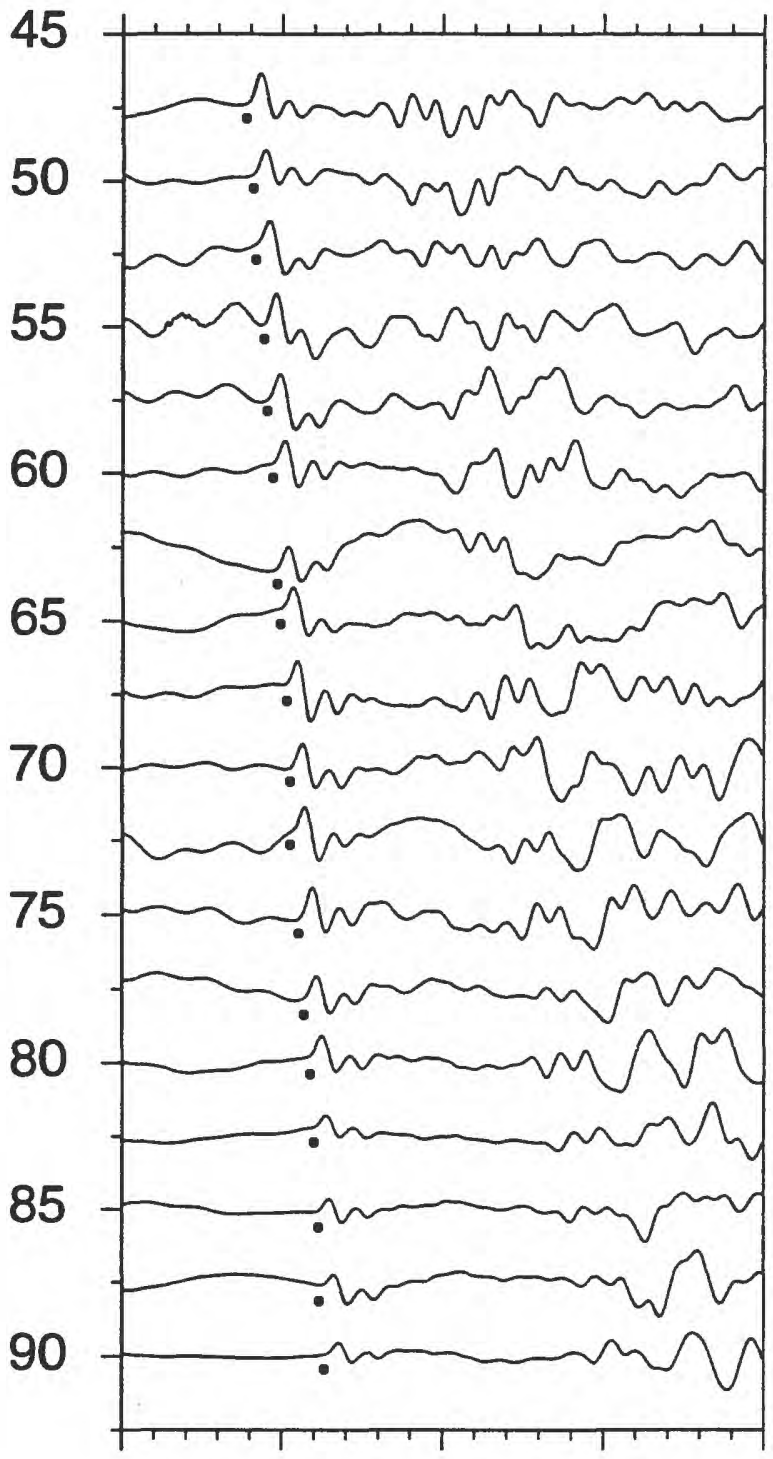

Sherman Oaks Woodman

Figure 57. Vertical component record section. P-wave arrivals are indicated by the solid circles. 


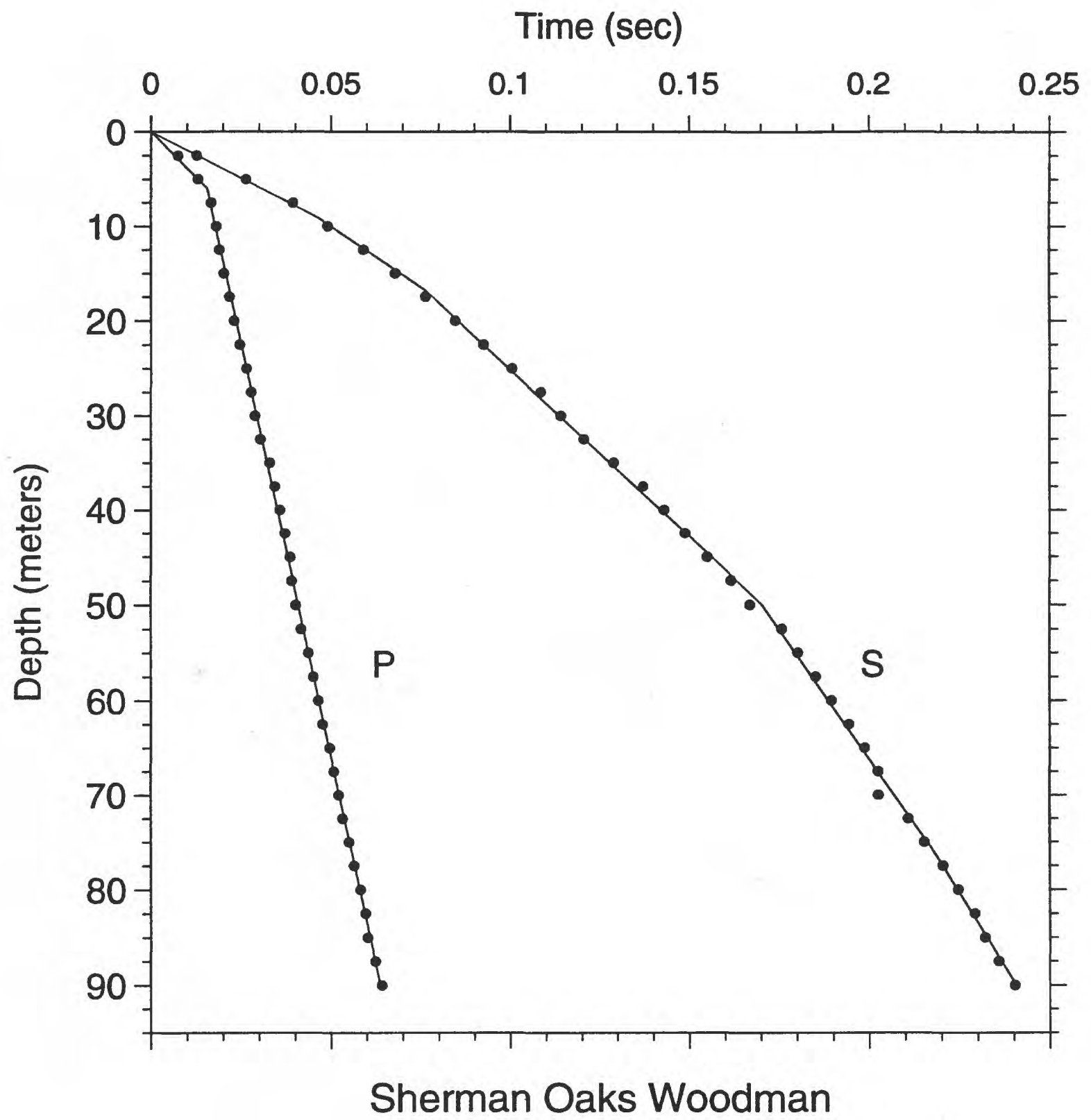

Figure 58. Time-depth graph of P-wave and S-wave picks. Line segments show the hinged-least-squares fit to the data points. 


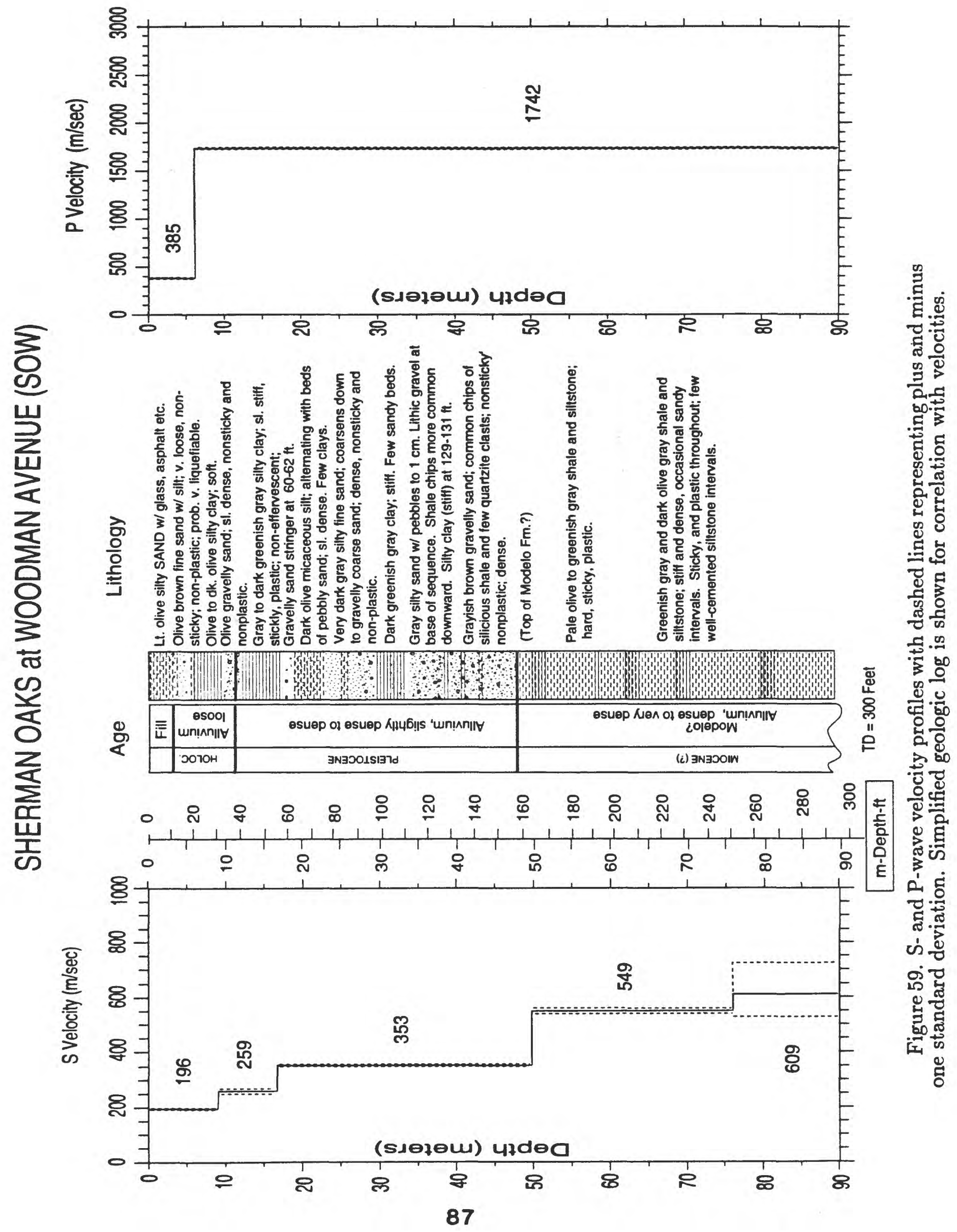




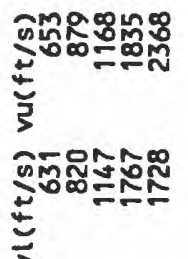

तै

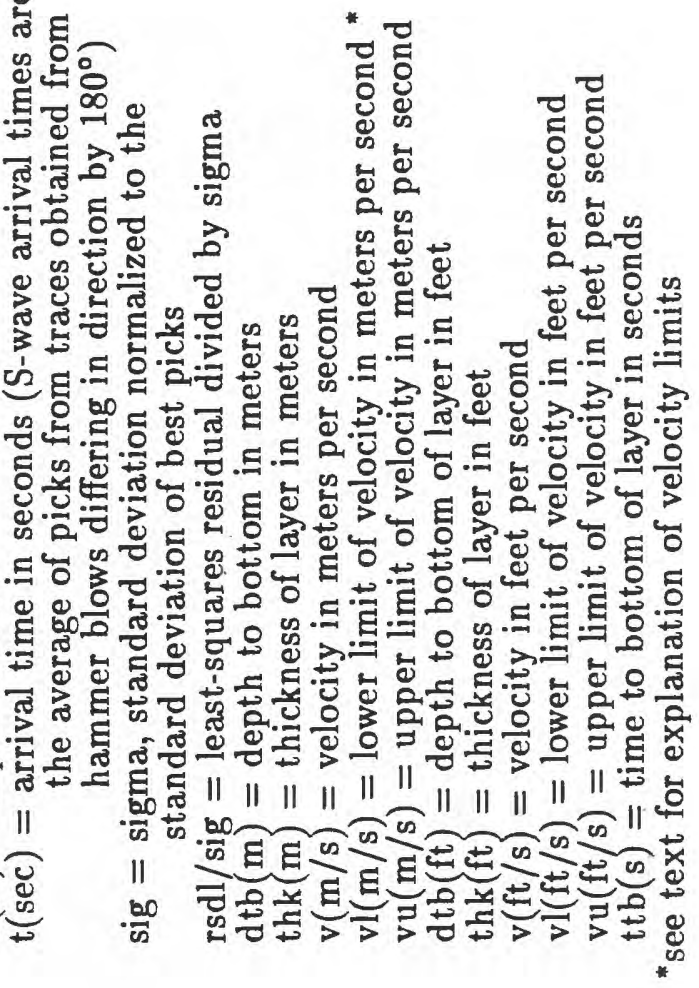

$$
\text { ำำ }
$$

Pamaom

亲

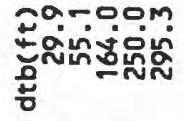

\section{密} .

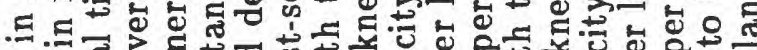

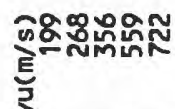

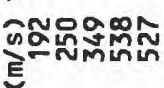
量

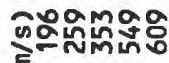

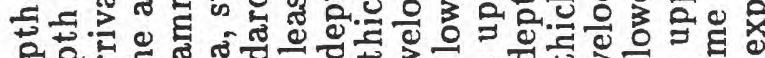

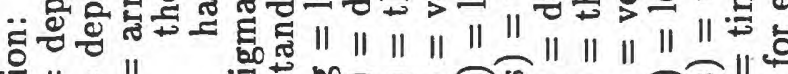

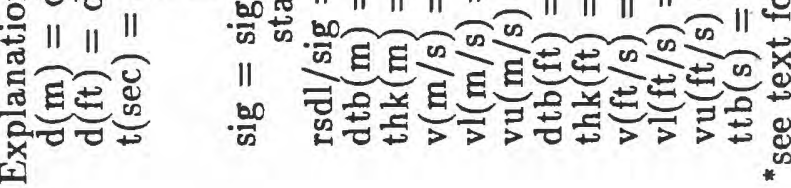
妾

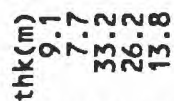

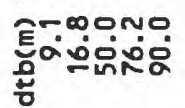

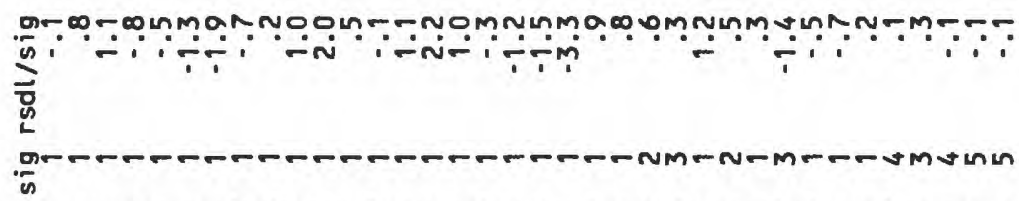

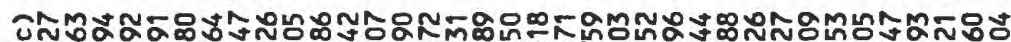

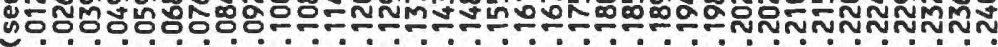

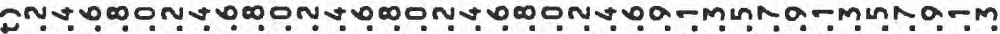

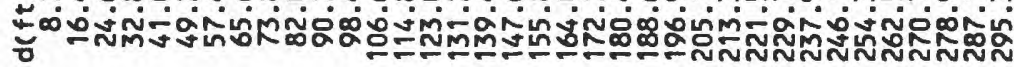

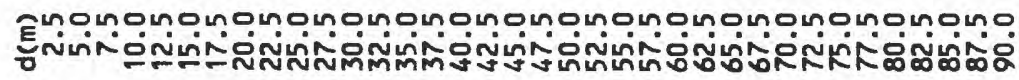


0
0
0

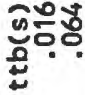

낭

巡。응

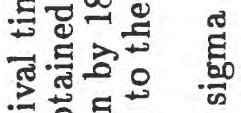

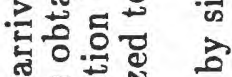

垴

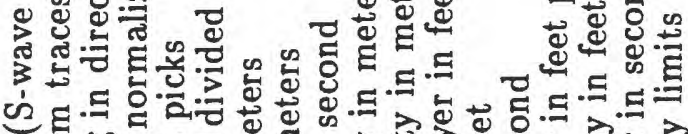

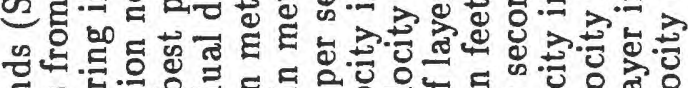

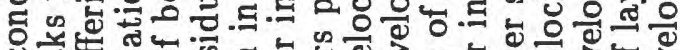

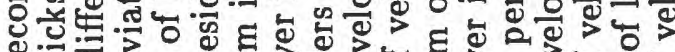

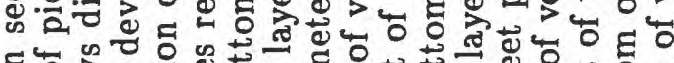

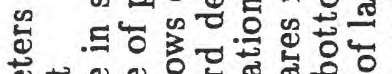
幽。

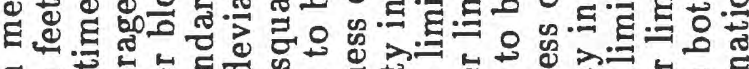
․․ㄹ

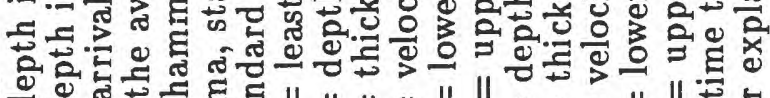

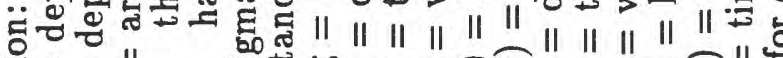

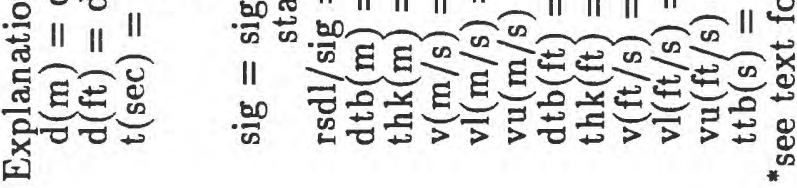

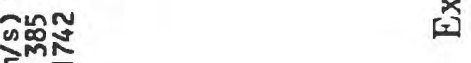

Eํㅇํㅇ

竞

兽送

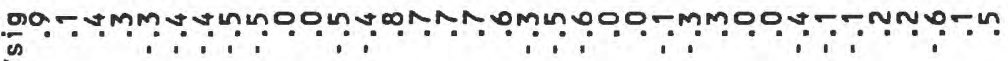

خ

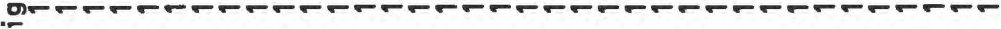

10

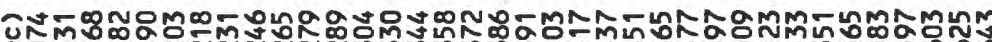

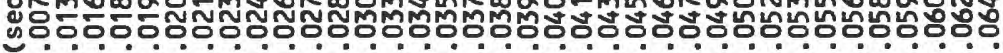

ON \%

Enomomomomomomomomomomomomomomomomono ซิ 


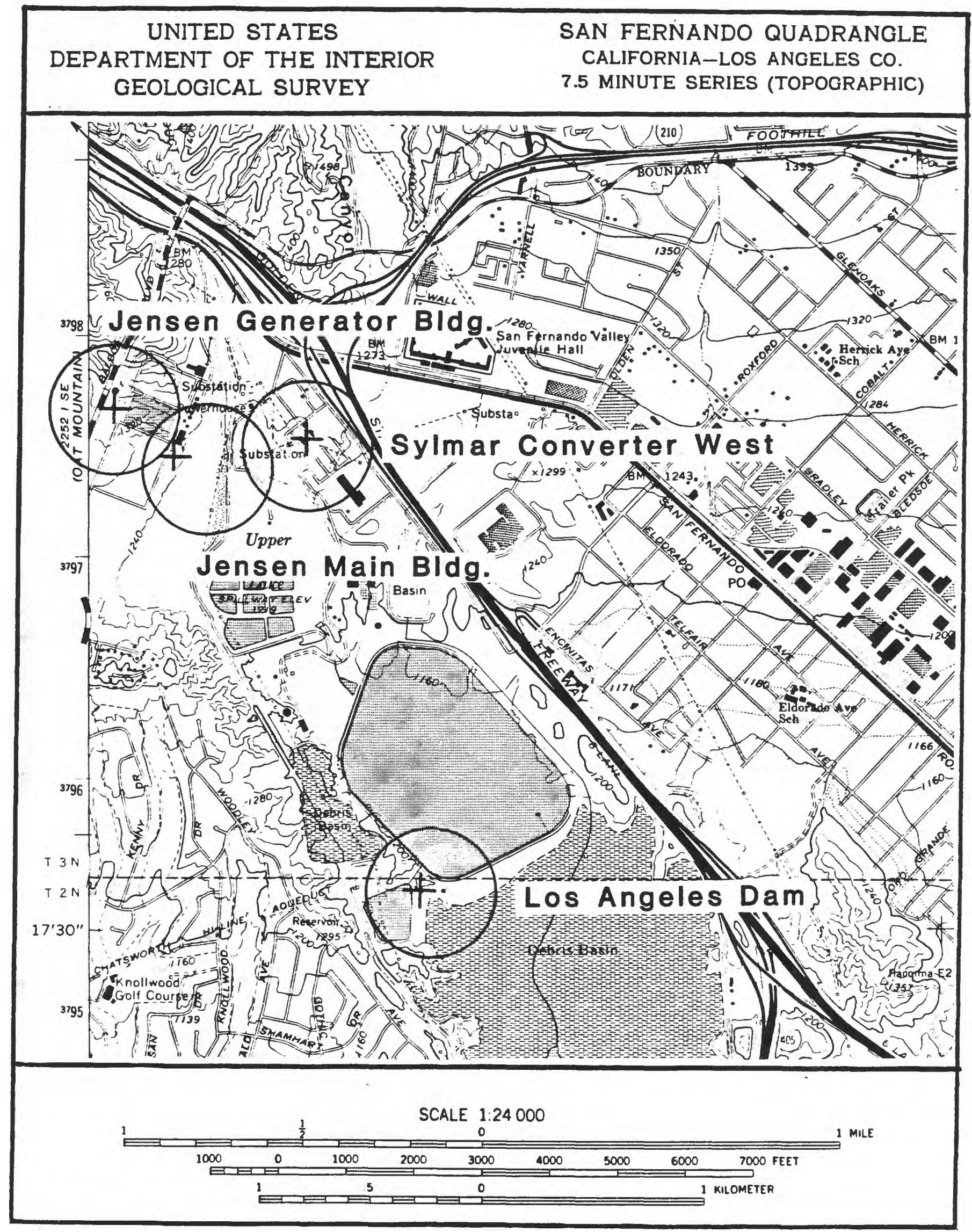

Figure 60. Site location map for the borehole at Sylmar Converter West. The accelerograph is located approximately 10 meters from the borehole. 


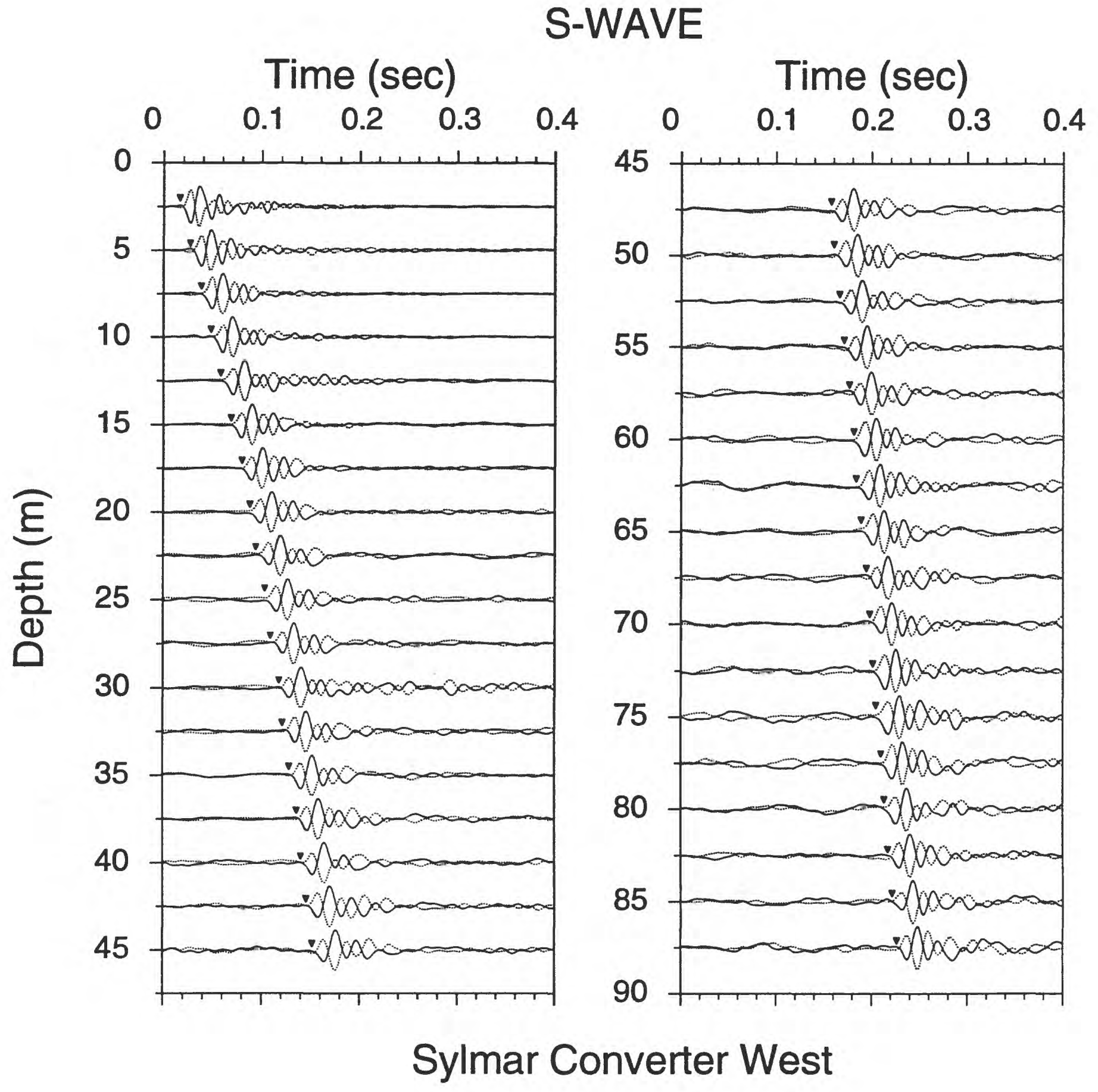

Figure 61. Horizontal component record section (from impacts in opposite directions) superimposed for identification of S-wave onset. Approximate S-wave time picks are indicated by the inverted triangles. 


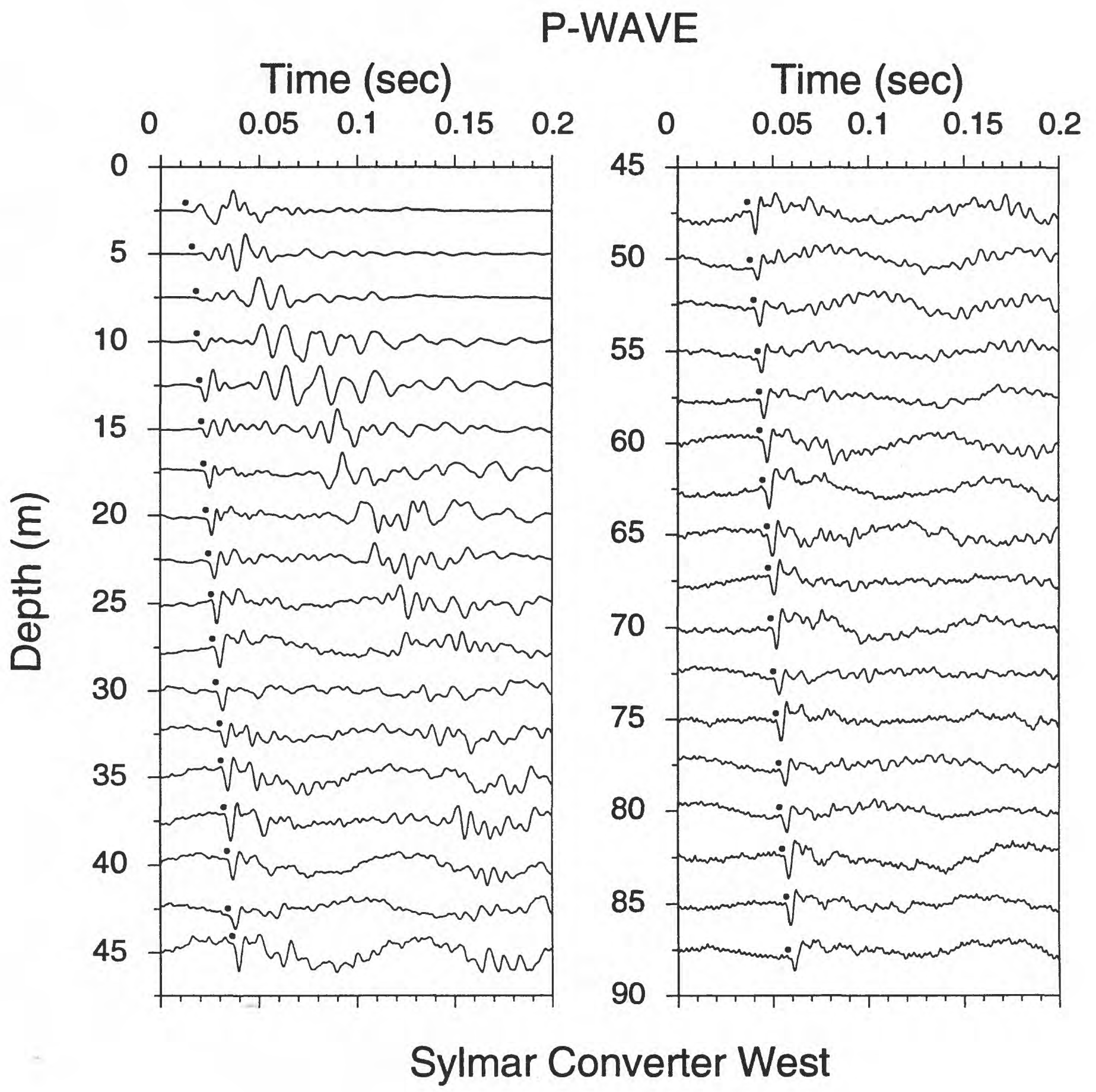

Figure 62. Vertical component record section. P-wave arrivals are indicated by the solid circles. 


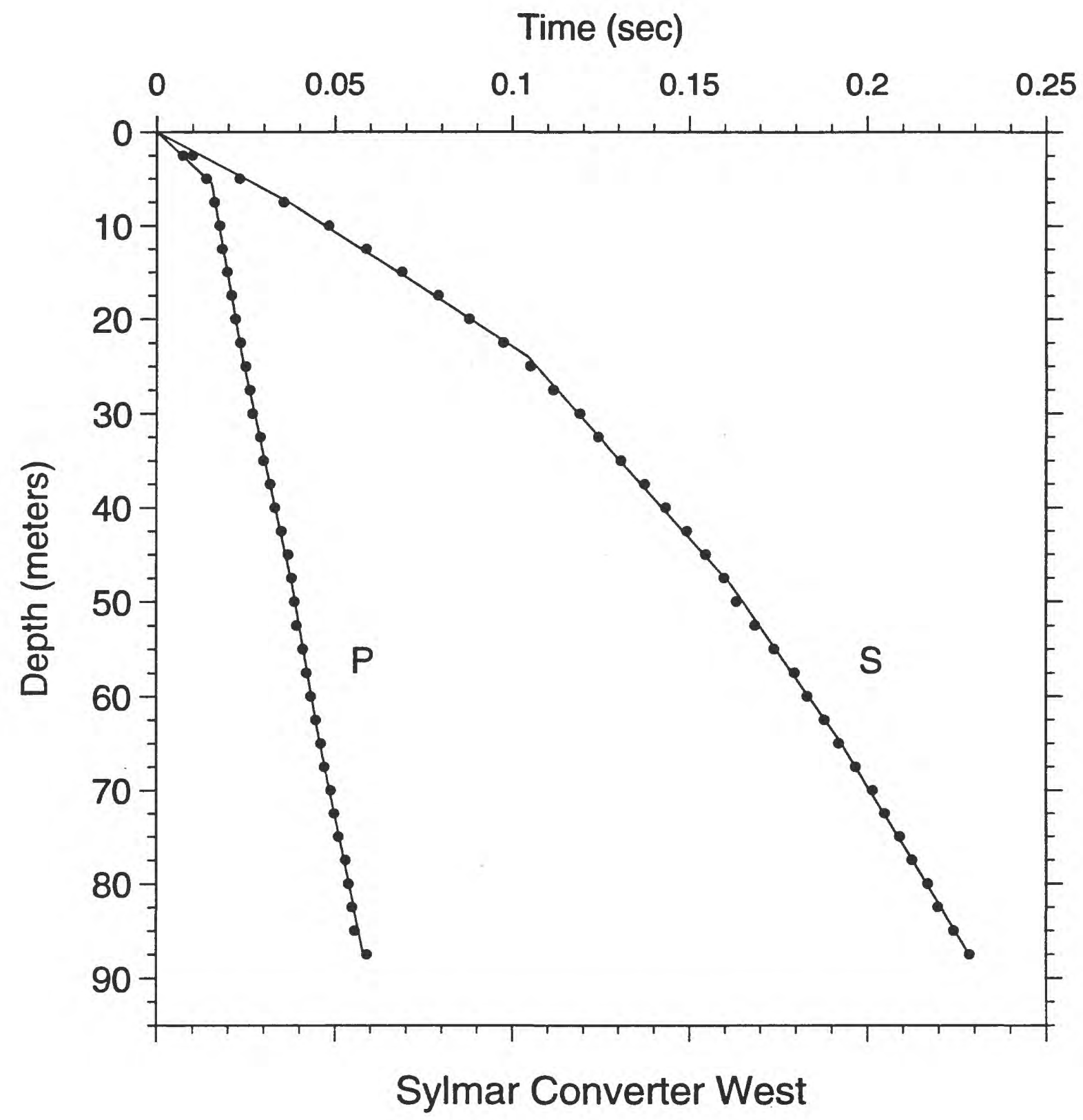

Figure 63. Time-depth graph of $\mathrm{P}$-wave and $\mathrm{S}$-wave picks. Line segments show the hinged-least-squares fit to the data points. 

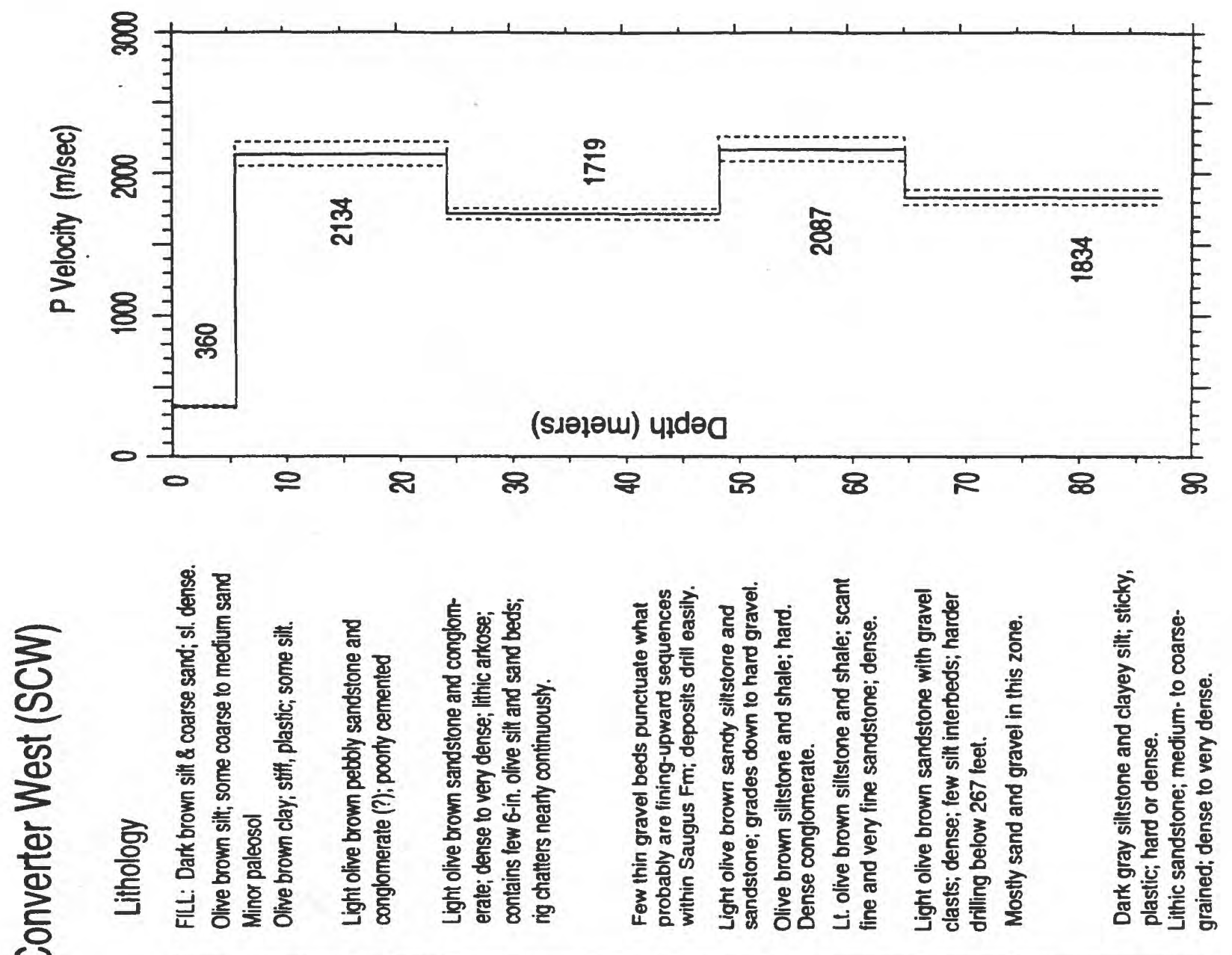

के है

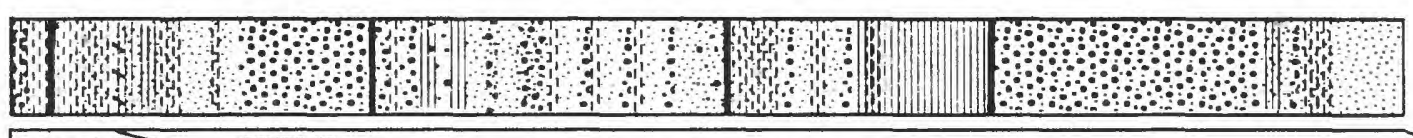

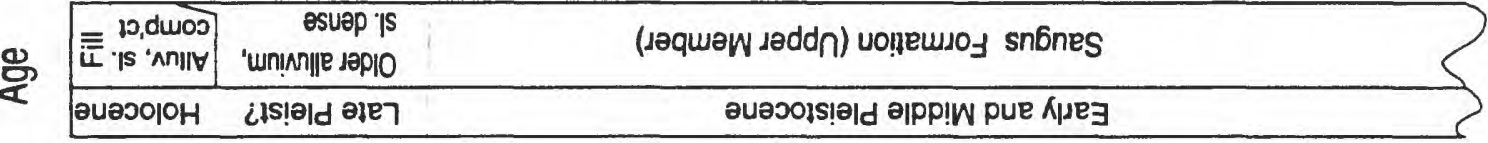

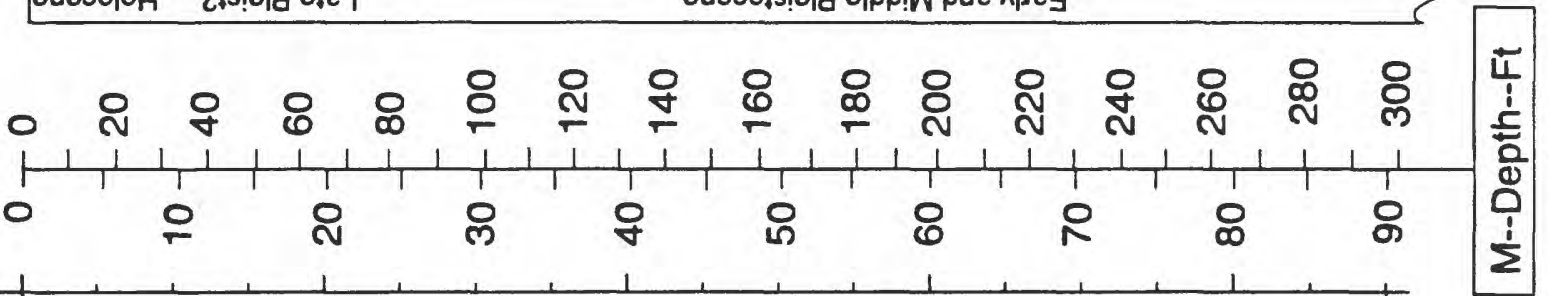

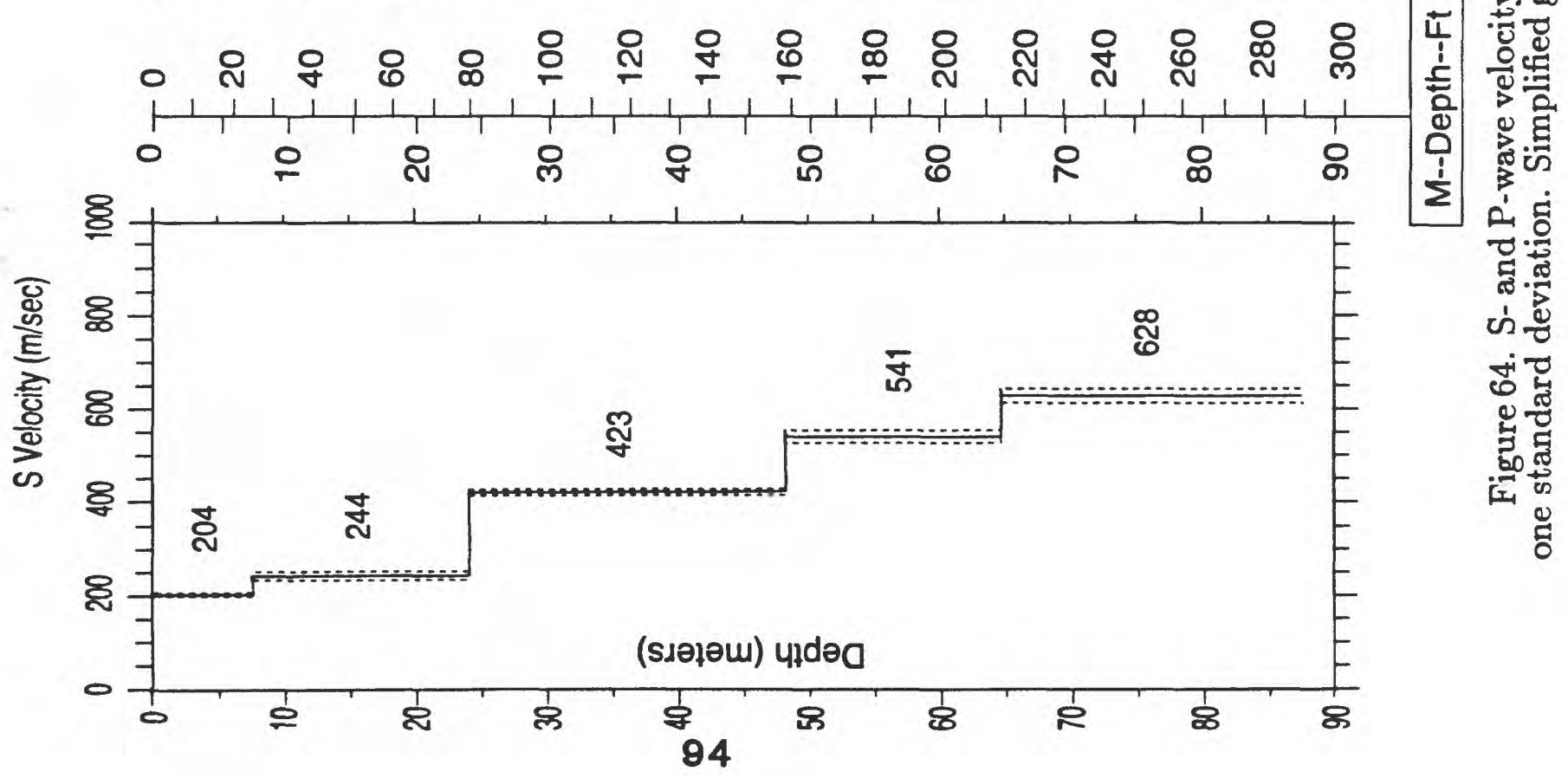




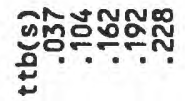

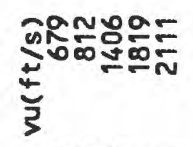

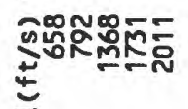

$\overline{>}$

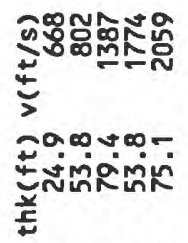

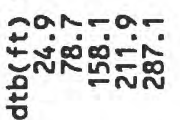

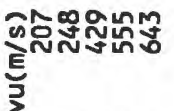

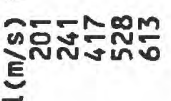

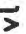

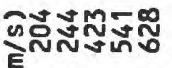

है

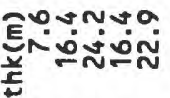

尊
เั้

ㅎํㅇㅇํㅇ

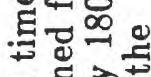

즈를 홍

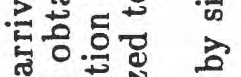

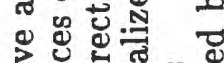

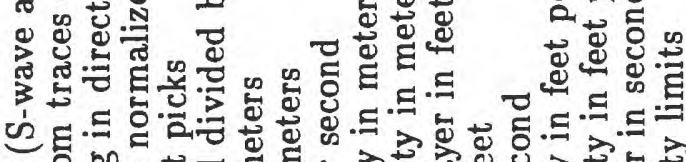

च ש.

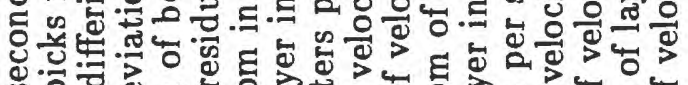

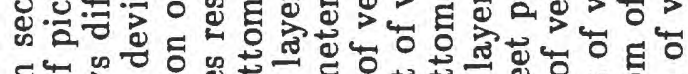

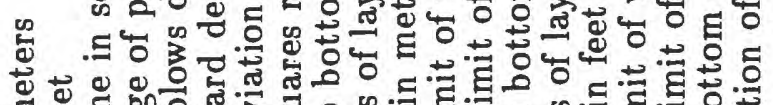

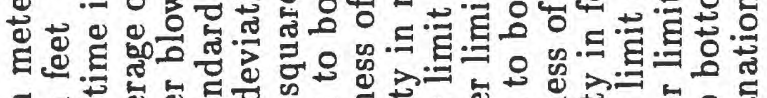

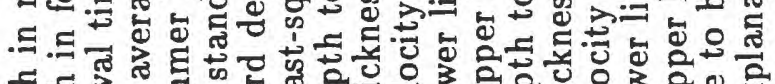

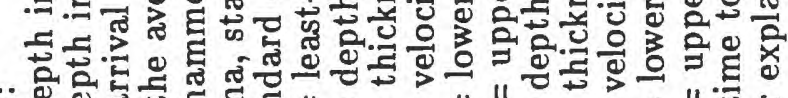

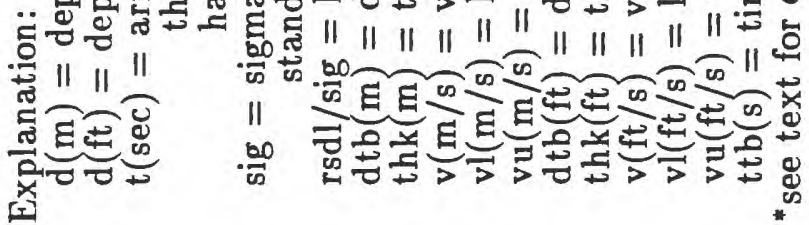

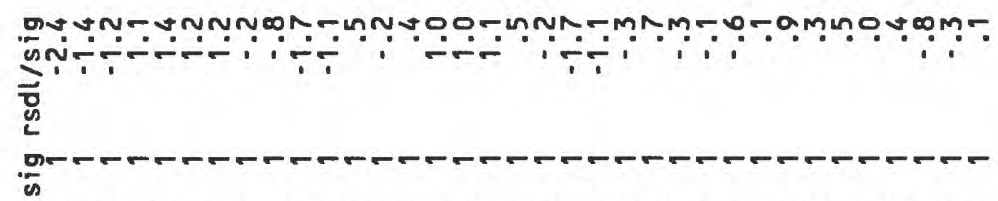

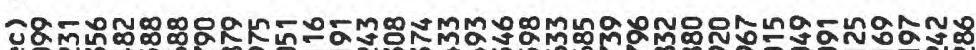

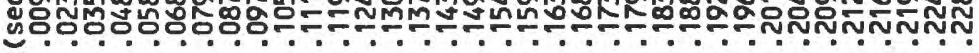

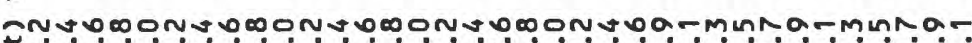

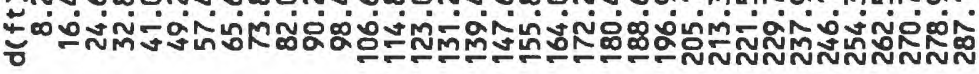

กิ่

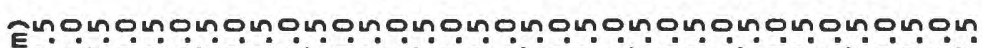

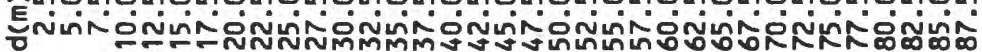




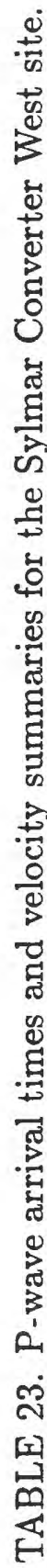

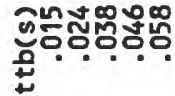

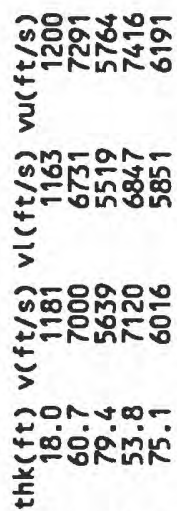

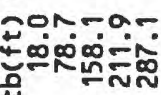

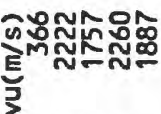

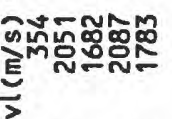

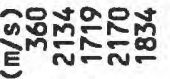

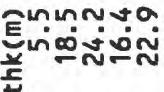

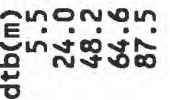

芯

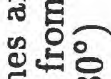

펀

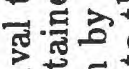

․ㅏㅇ

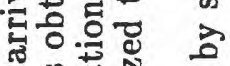

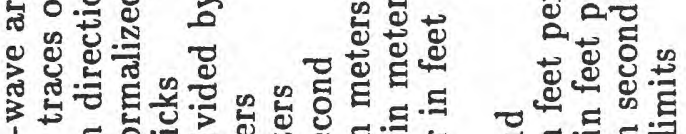

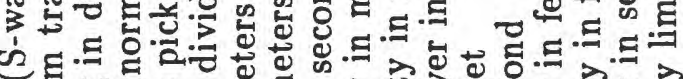

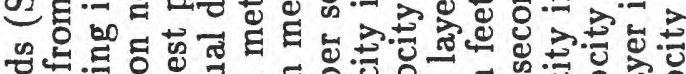

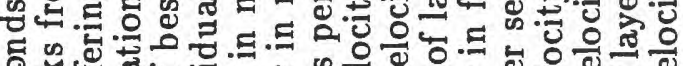

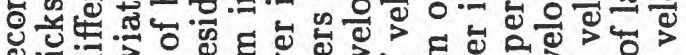

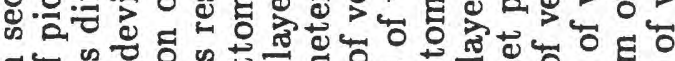

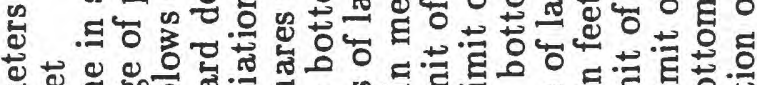

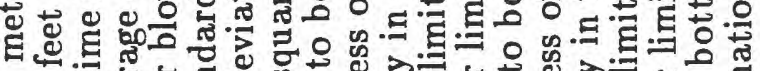

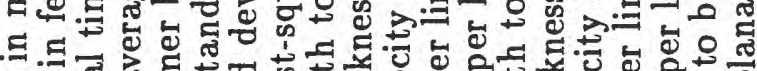

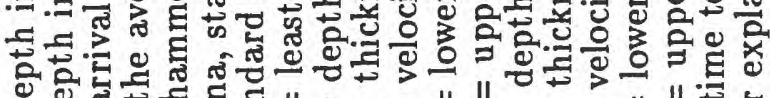

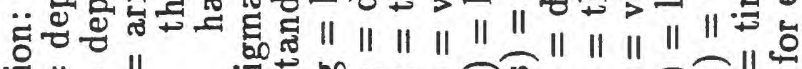

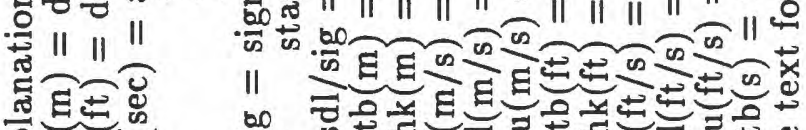

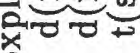

땜

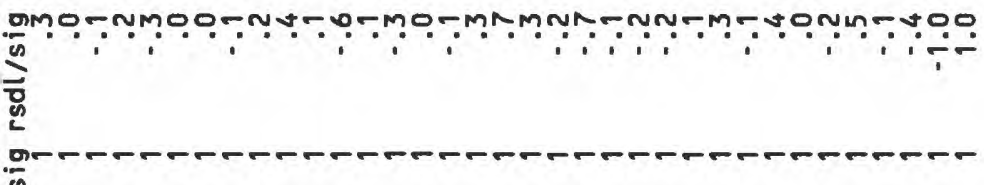

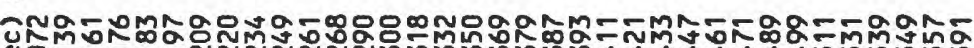

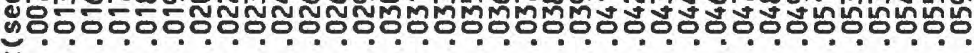

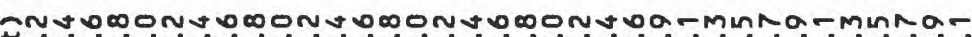
ช

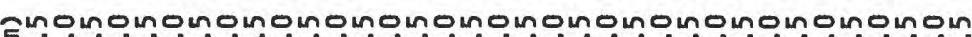

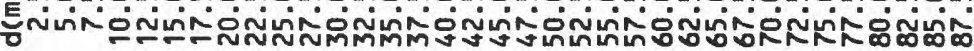




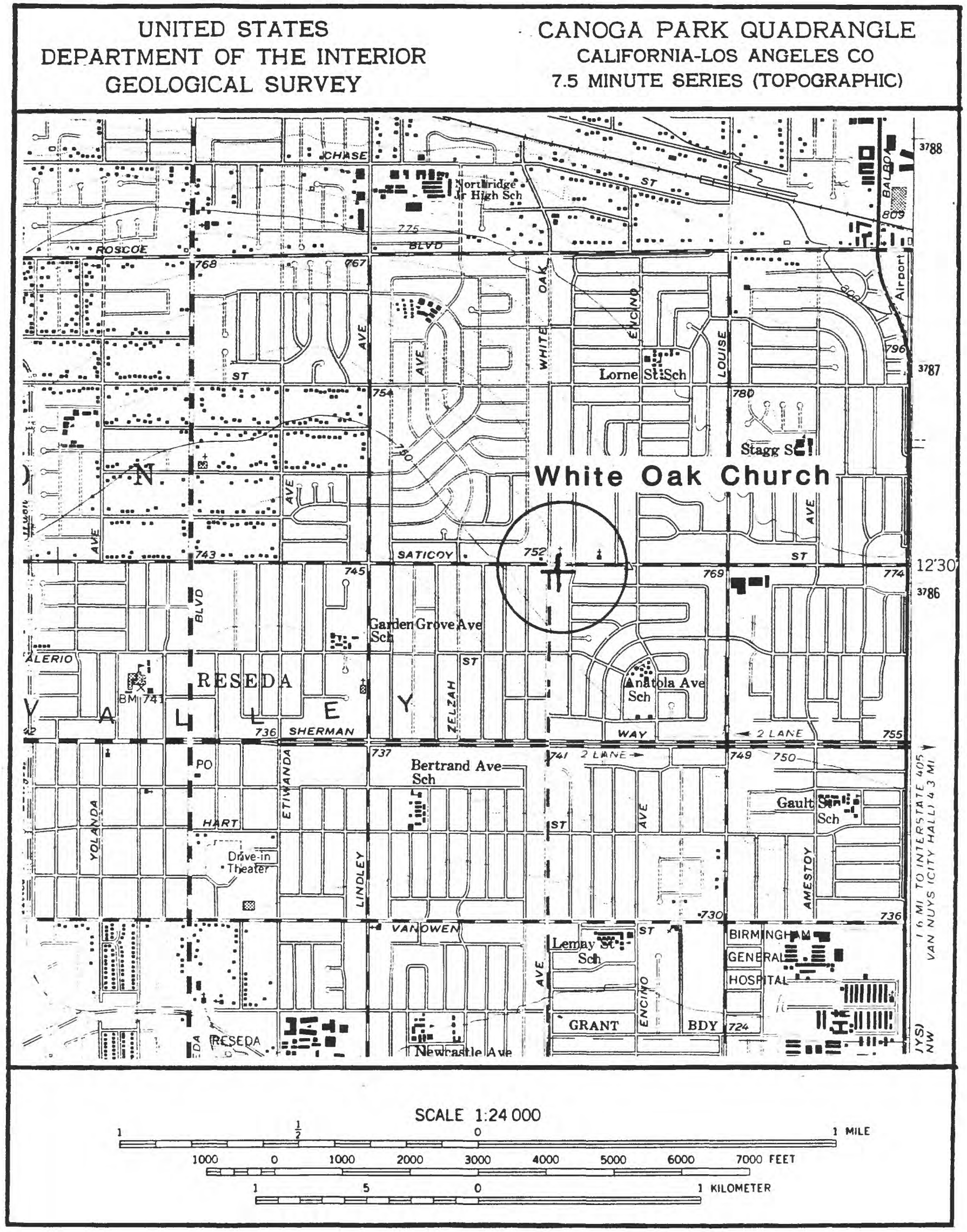

Figure 65. Site location map for the borehole at White Oak Church. The accelerograph is located approximately 50 meters from the borehole. 


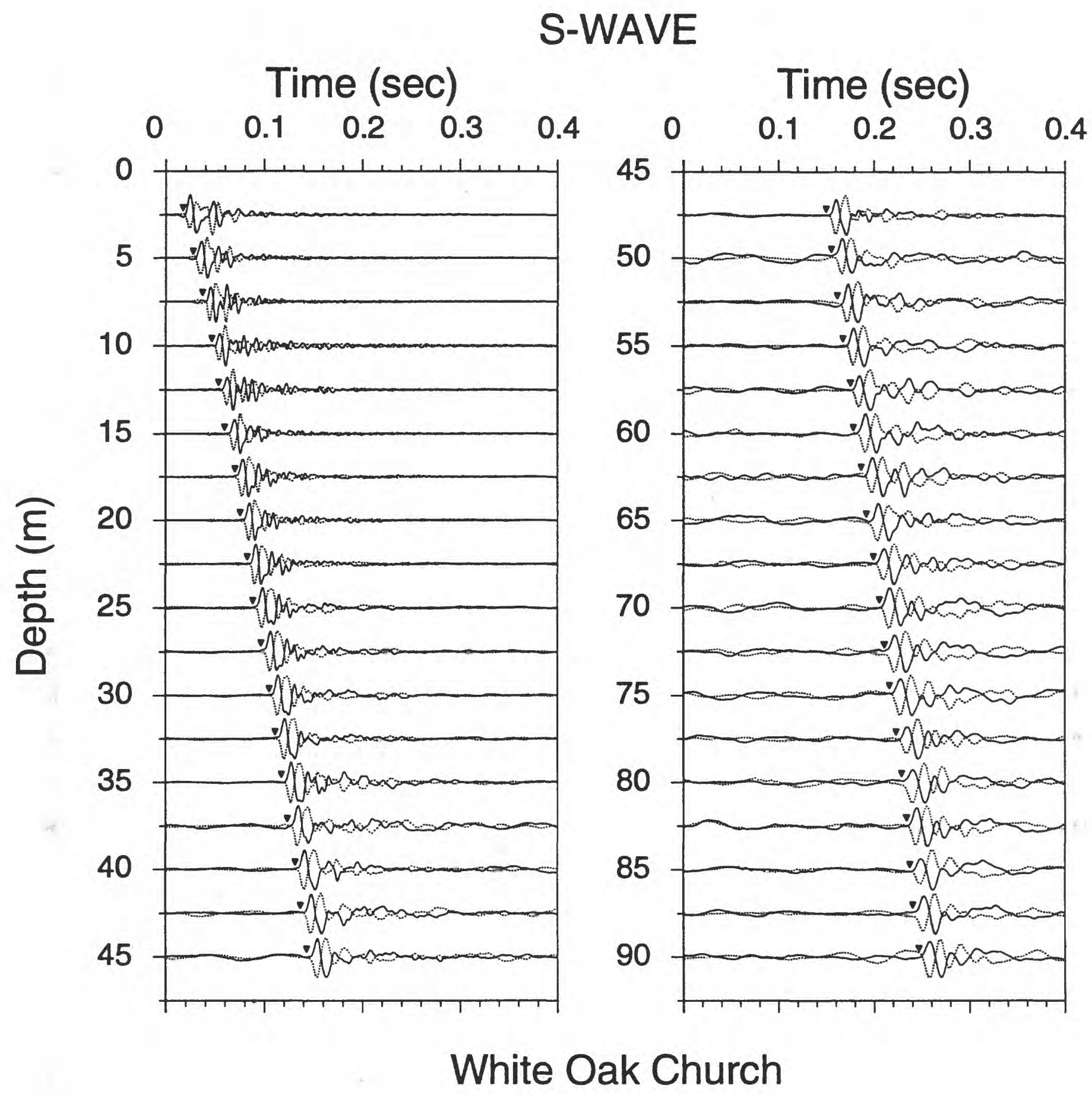

Figure 66. Horizontal component record section (from impacts in opposite directions) superimposed for identification of S-wave onset. Approximate S-wave time picks are indicated by the inverted triangles. 


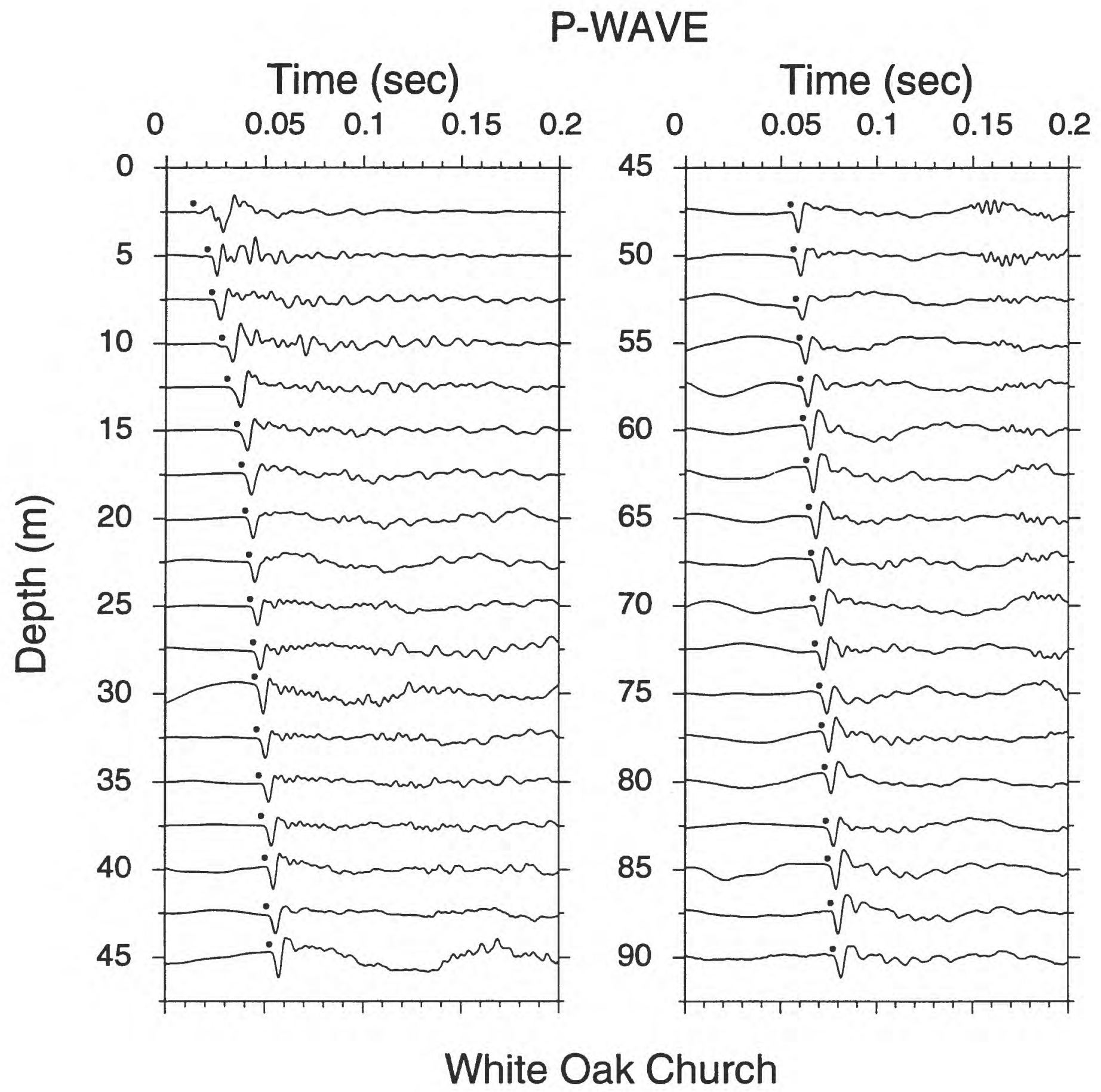

Figure 67. Vertical component record section. P-wave arrivals are indicated by the solid circles. 


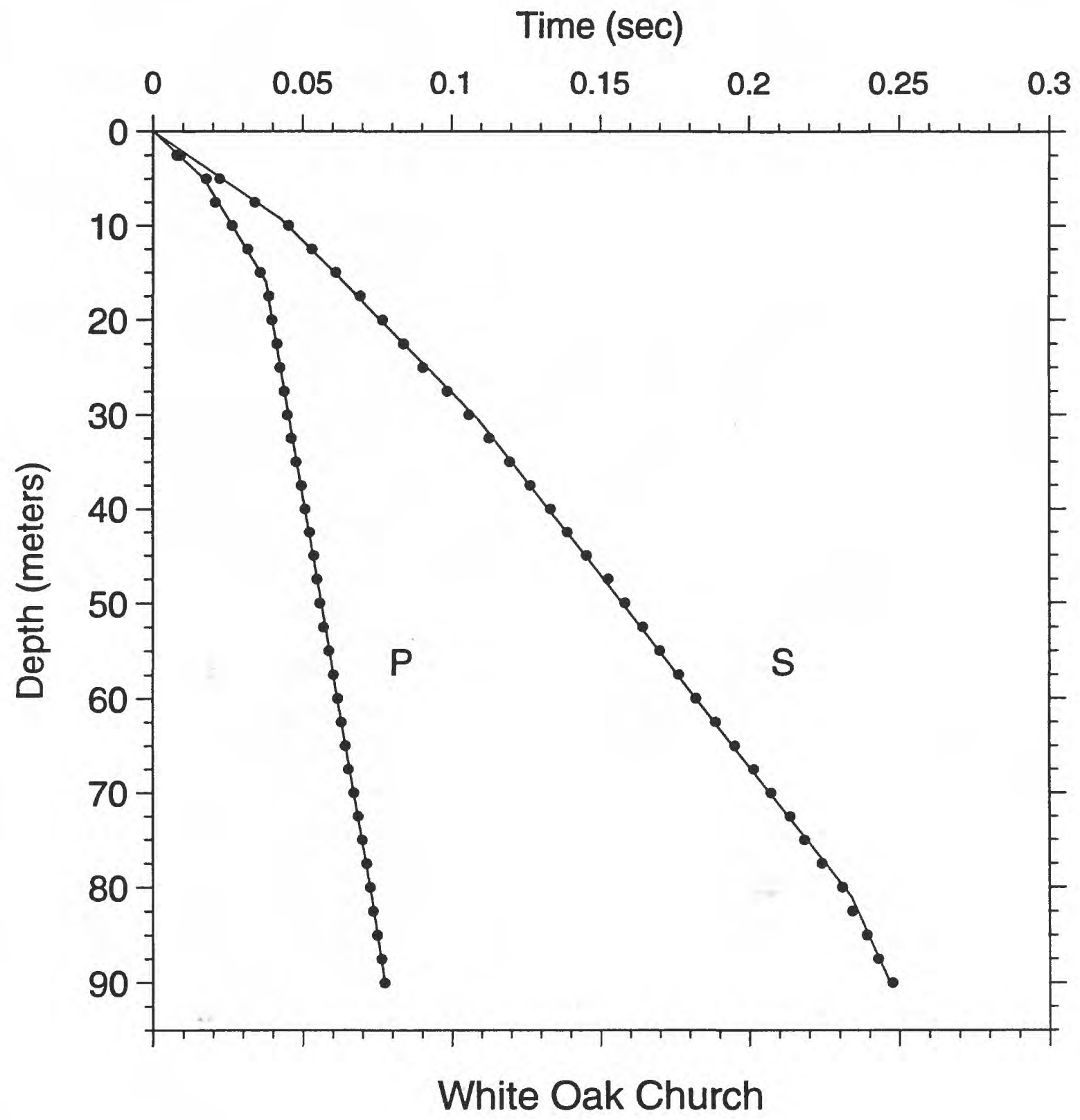

Figure 68. Time-depth graph of P-wave and S-wave picks. Line segments show the hinged-least-squares fit to the data points. 


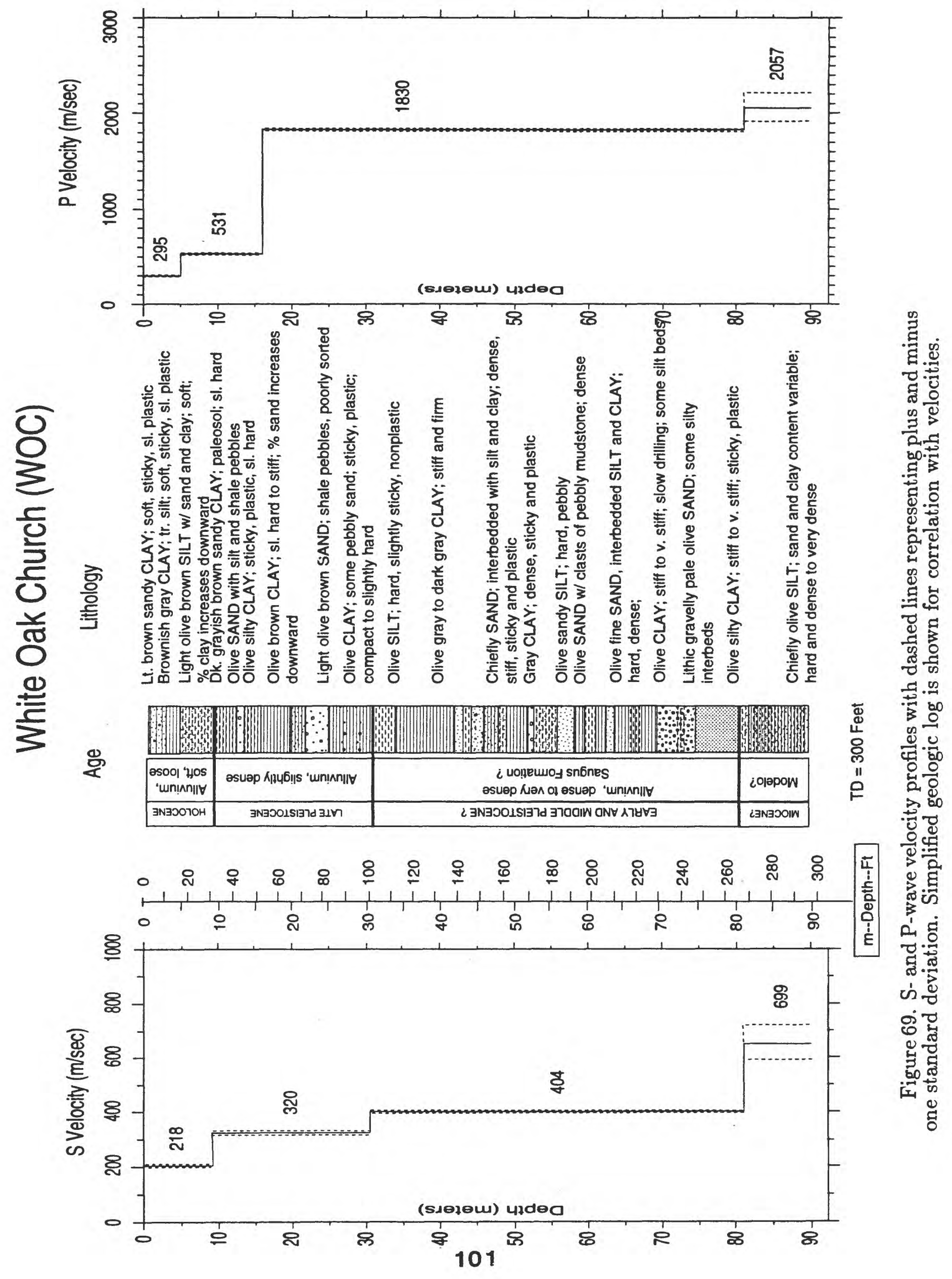




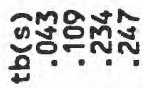

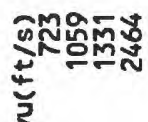

สั้

ษ。ํㅇ응

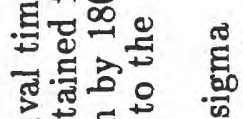

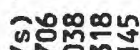

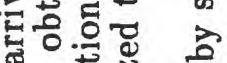

艺

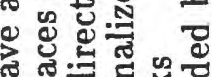

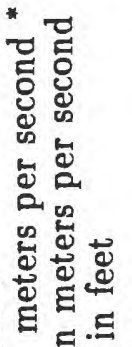

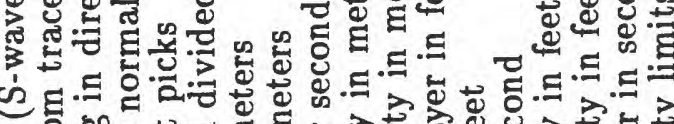

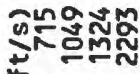

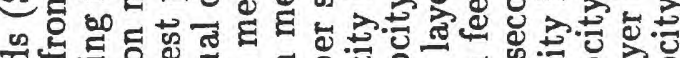
on 0

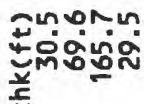

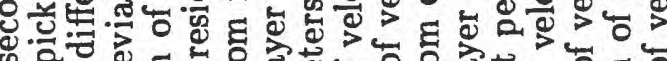

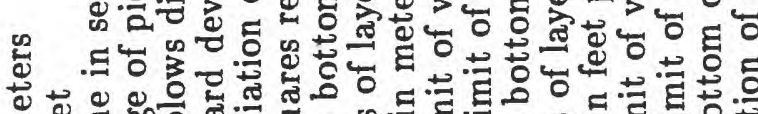
an- $n$ m 원. E. 5 嵌

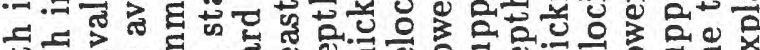
폴 의

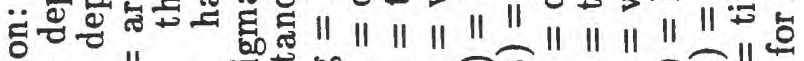

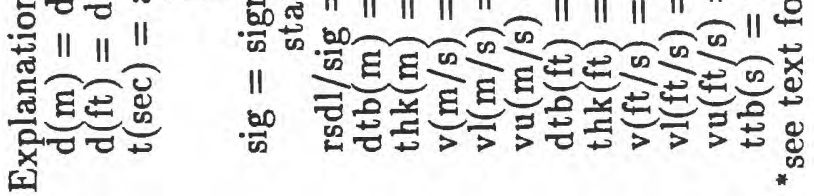

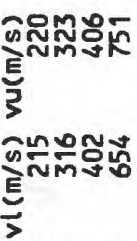

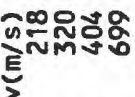
हैंmingo

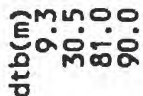

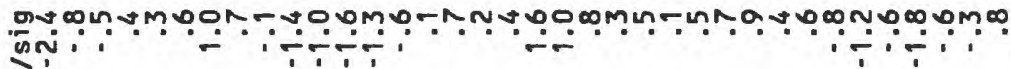
す⿺

- ำ

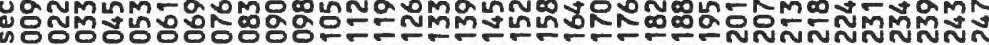

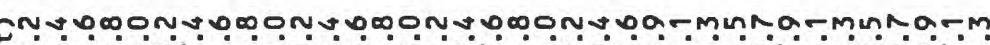
ช

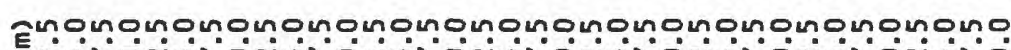

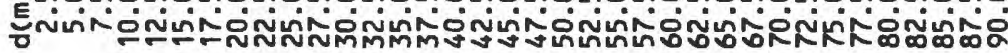




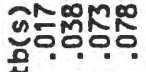

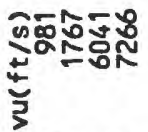

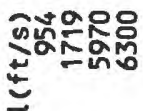

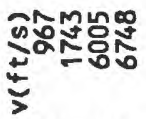

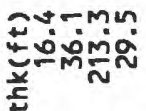

Stungm

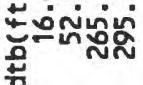

굴

눙

.

ส

宗

密

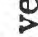

물

a

.

สี

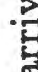

望

ก

미

网

画

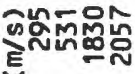

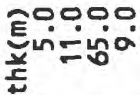

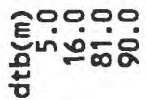
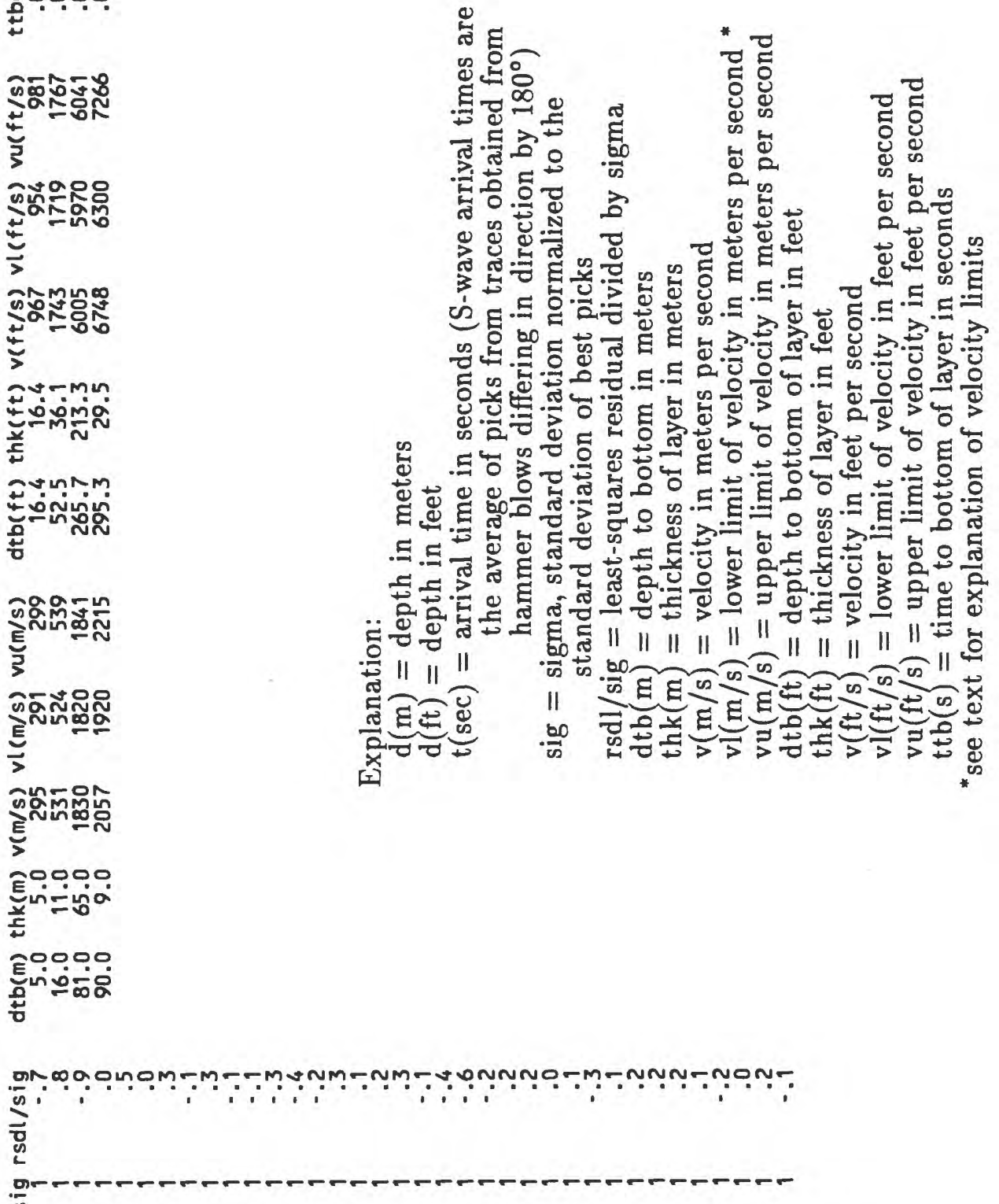

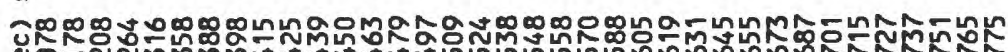

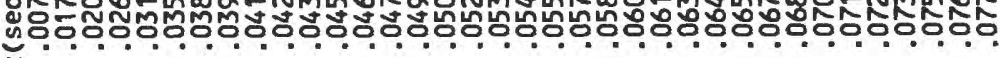

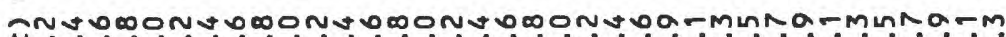
†

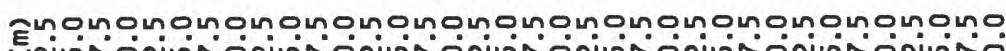

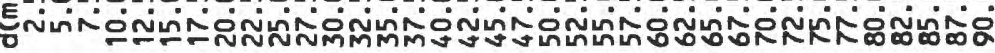

